\title{
Field Guide to Hydrothermal Alteration in the White River Altered Area and in the Osceola Mudflow, Washington
}

By David A. John, James J. Rytuba, Roger P. Ashley, Richard J. Blakely, James W. Vallance, Grant R. Newport, and Gary R. Heinemeyer

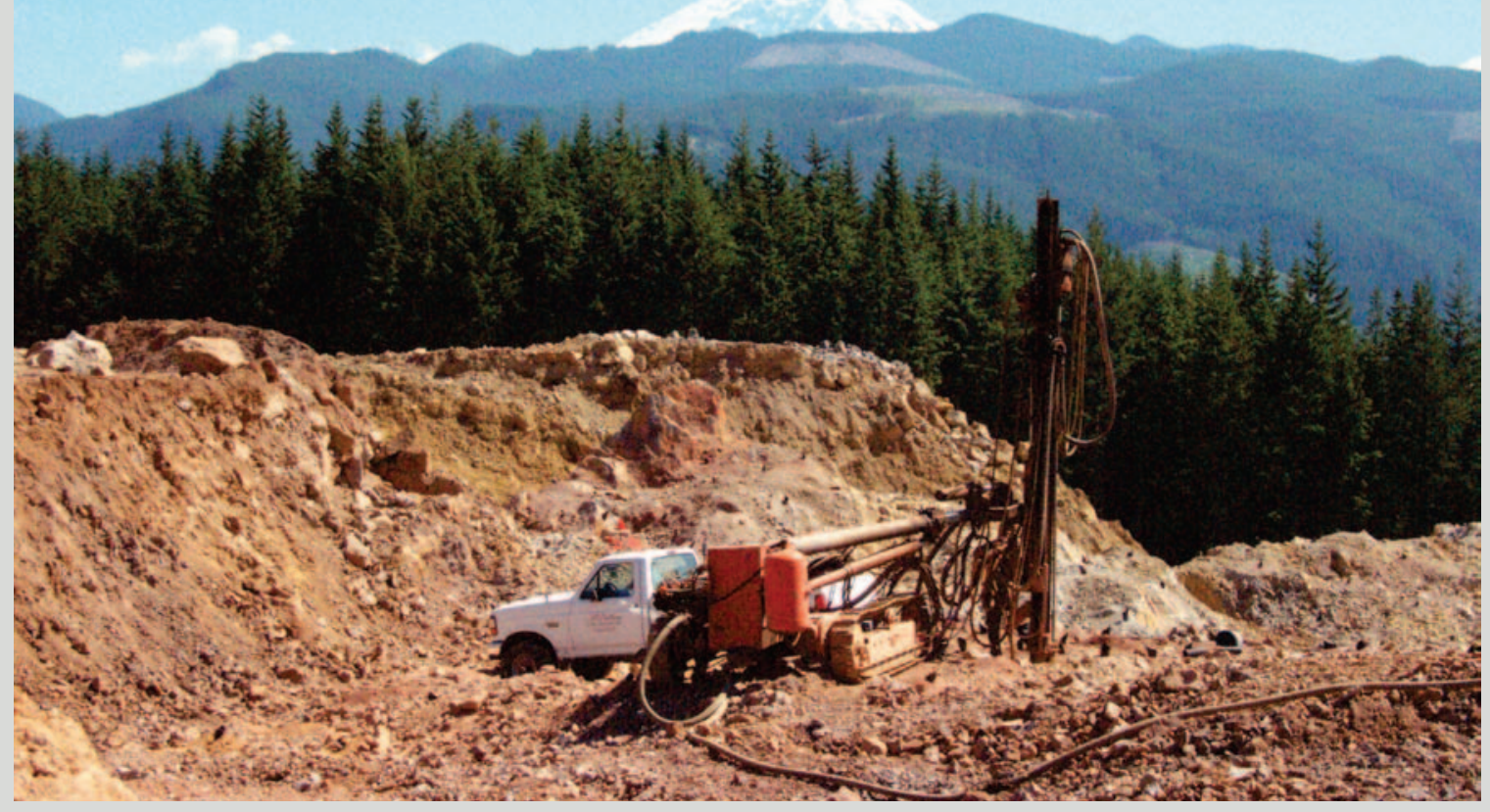

Prepared for the Society of Economic Geologists Field Trip, November 6, 2003

Bulletin 2217 


\section{Field Guide to Hydrothermal Alteration in the White River Altered Area and in the Osceola Mudflow, Washington}

By David A. John, James J. Rytuba, Roger P. Ashley, Richard J. Blakely, James W. Vallance, Grant R. Newport, and Gary R. Heinemeyer

Bulletin 2217 


\section{U.S. Department of the Interior}

Gale A. Norton, Secretary

\section{U.S. Geological Survey}

Charles G. Groat, Director

Any use of trade, product, or firm names in this publication is for descriptive purposes only and does not imply endorsement by the U.S. Government.

\section{U.S. Geological Survey, Reston, Virginia: 2003}

Electronic copies of this publication are available online at http://geopubs.wr.usgs.gov/bulletin/b2217/

Additional USGS publications can be found online at http://geology.usgs.gov/products.html

For more information about the USGS and its products:

Telephone: 1-888-ASK-USGS (1-888-275-8747)

World Wide Web: http://www.usgs.gov/

Published in the Western Region, Menlo Park, California

Manuscript approved for publication October 25, 2003 


\section{Contents}

Introduction

Road log from Enumclaw to the White River Altered Area and the Osceola Mudflow along the lower White River, Washington .................................................................................. 2

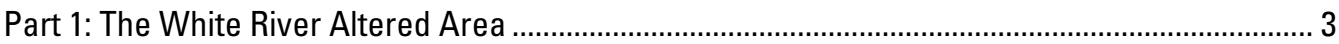

Geology of the White River Altered Area ……………............................................................ 3

Economic Geology of the White River Altered Area-Historical Perspective .......................... 4

Hydrothermal Alteration and Mineralization in the White River Area ..................................... 4

Geophysical Framework of the White River Altered Area......................................................... 6

Geochemical Exploration Studies of the White River Altered Area............................................ 7

Stop 1: Superior (Ash Grove) Silica Quarry .......................................................................... 9

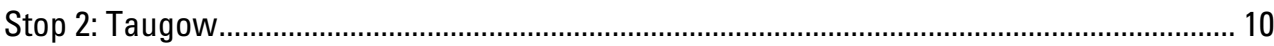

Stop 3: Scatter Creek (James Hardie) Silica Quarry ............................................................. 10

Part 2: The Osceola Mudflow in the Lower White River ............................................................... 11

General Features of the Osceola Mudflow ........................................................................... 11

Hydrothermal Alteration in the Osceola Mudflow ............................................................. 12

Stop 4: Osceola Mudflow near Greenwater........................................................................ 13

Stop 5: Osceola Mudflow in the Corliss Gravel Quarry ........................................................ 13

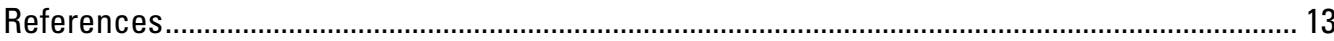

\section{Figures}

1. Map showing location of the Western Cascades and High Cascades arcs and associated mineral deposits, northwestern United States................................................. 16

2. Map showing areas inundated by Holocene debris flows from Mount Rainier ....................... 17

3. Photograph of vuggy silica alteration in the Scatter Creek (James Hardie) silica quarry ..... 17

4. Geologic map of the White River area, showing field trip stops ............................................. 18

5. Heterolithic breccia (lahar) in the Fifes Peak Formation ........................................................ 20

6. Finely bedded tuffs from small outcrop about $0.5 \mathrm{~km}$ north of the Superior quarry.................. 20

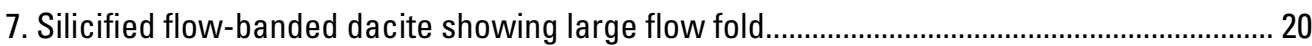

8. Map showing distribution of hydrothermal alteration in the White River area ......................... 21

9. Photo of leached phenocrysts in vuggy silica alteration in the Scatter Creek quarry ............ 22

10. Photo showing sharp contact between vuggy silica alteration and advanced argillic

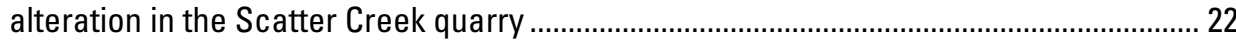

11. Schematic model for high-sulfidation gold deposits, showing zoning of hydrothermal

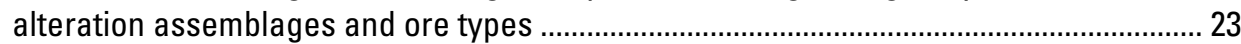

12. $\mathrm{Log} \mathrm{fO}_{2}$-pH diagram showing fluid relations forming vuggy silica alteration ........................... 23

13. Aeromagnetic anomalies of the White River altered area and surrounding regions............... 24

14. Cross sections of IP surveys across the White River altered area ......................................... 25

15. Geophysical anomalies of the White River altered area and surrounding regions ................. 26

16. Ground magnetic studies of the White River altered area ................................................... 27

17. Ground magnetic profile across White River altered zone ..................................................... 28

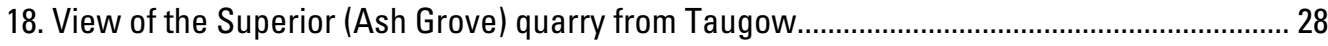

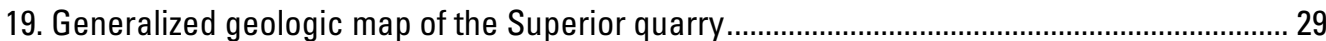

20. Gray vuggy silica rock with abundant voids after phenocrysts in andesite flow..................... 30

21. Photographs of sulfide minerals in vuggy silica from the Superior quarry .............................. 30

22. Enargite filling funnel-shaped void in white chalcedonic silica in the Superior quarry .......... 30 
23. Tan chalcedony replacing relict flow and devitrification layers in dacite flow in the Superior quarry.

24. Massive tan chalcedony cut by hydrothermal breccias with sulfides in gray areas in the Superior quarry.

25. Felsic porphyry dike in the Superior quarry.

26. Hydrothermal breccia with clasts of early stage white chalcedony in tan to gray chalcedony with sulfides in gray areas in the Superior quarry 32

27. Sulfide-bearing hydrothermal breccia developed in massive tan silicified rock in the Superior quarry.

28. Massive tan silicified rock cut by stockwork of sulfide-bearing gray chalcedony in the Superior quarry.

29. Brecciated siliceous hydrothermal sedimentary rocks in the Superior quarry 33

30. Fault breccia with clay-supported fragments that contains high gold content (1.7 ppm) in the Superior quarry.

31. North-striking fault with red clay gouge developed in massive vuggy silica rock ................... 33

32. Red to brown smectite clay zone developed from alteration of bedded tuff ............................ 34

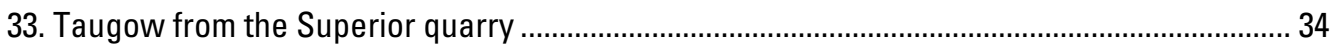

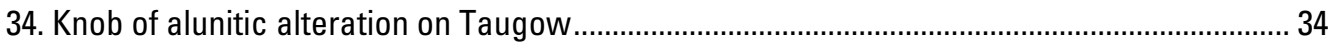

35. Leached silicified tuff breccia with relict pyroclastic textures exposed in road cut near top of Taugow .35

36. Narrow fine-grained silicic dike cutting silicified tuff breccia near top of Taugow................ 35

37. Blocks of vuggy silica alteration in hydrothermal breccia near top of Taugow....................... 35

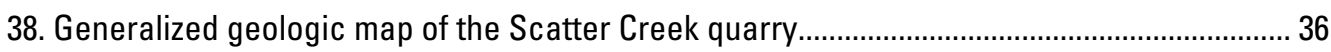

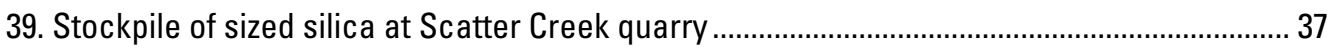

40. Gray vuggy silica rock cut by white quartz and chalcedony veins and hydrothermal breccias in the Scatter Creek quarry. 37

41. Voids developed in porphyritic andesite after leached plagioclase and pyroxene phenocrysts by acid hydrothermal fluids leaving a residual ground mass of silica 37

42. Northeast-trending rib of orangish-brown vuggy silica alteration in the Scatter Creek

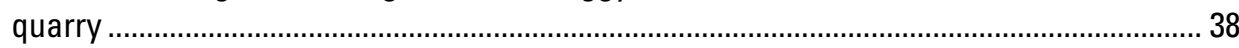

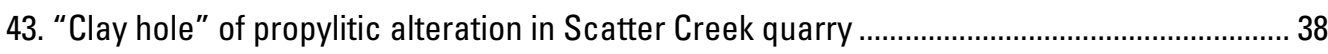

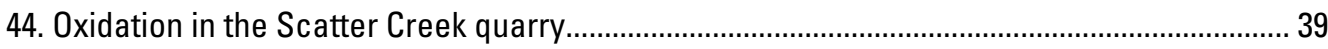

45. Vuggy silica cut by white chalcedonic hydrothermal breccia and veins in the Scatter Creek quarry

46. Vuggy silica cut by hydrothermal breccias in the Scatter Creek quarry 40

47. Fracture in vuggy silica filled with late stage hydrothermal red clay in the Scatter Creek quarry

48. White outcrops of leached rock formed in the near-surface steam-heated zone in the Scatter Creek quarry

49. Map showing distribution of the Osceola Mudflow and Paradise lahar ................................. 41

50. Dark-gray clay-pyrite rich matrix of the Osceola Mudflow................................................... 42

51. Typical outcrop of the Osceola Mudflow along the White River near Greenwater, Washington 42

52. Typical smectite-pyrite alteration of andesite clast in the Osceola Mudflow........................ 42

53. Back-scattered SEM image of smectite alteration of andesite clast in the Osceola Mudflow..... 43

54. Back-scattered SEM image of smectite-pyrite alteration of andesite clast in the Osceola Mudflow

55. Back-scattered SEM image of advanced argillic altered clast in Osceola Mudflow ............. 43

56. Back-scattered SEM image of advanced argillic altered clast in Osceola Mudflow ............. 44

57. Back-scattered SEM image of intergrown alunite and kaolinite in advanced argillic altered clast in the Osceola Mudflow 
58. Back-scattered SEM image of alunite containing P-rich domains in advanced argillic altered clast in the Osceola Mudflow.

59. Back-scattered SEM image of vug-filling anhydrite/gypsum and fluorite in advanced argillic altered clast in the Osceola Mudflow

60. Schematic diagram showing formation of normal zoning by incremental deposition model for mass flow deposits 45

61. Exposure of Osceola Mudflow overlying well bedded late Pleistocene glacial-fluvial deposits in the Corliss quarry... . .46

62. Partly charred trees protruding from the Osceola Mudflow in the Corliss quarry ................... 46

63. Base of the Osceola Mudflow in the Corliss quarry ............................................................ 46

\section{Tables}

1. Mineral assemblages in the White River altered area .......................................................... 47

2. Types of silicic alteration in the White River altered area ...................................................... 48 


\title{
Field Guide to Hydrothermal Alteration in the White River Altered Area and in the Osceola Mudflow, Washington
}

\author{
By David A. John', James J. Rytuba', Roger P. Ashley', Richard J. Blakely', James W. Vallance'², Grant R. \\ Newport ${ }^{3}$, and Gary R. Heinemeyer ${ }^{4}$
}

\section{Introduction}

The Cenozoic Cascades arcs of southwestern Washington are the product of long-lived, but discontinuous, magmatism beginning in the Eocene and continuing to the present (for example, Christiansen and Yeats, 1992). This magmatism is the result of subduction of oceanic crust beneath the North American continent. The magmatic rocks are divided into two subparallel, north-trending continental-margin arcs, the Eocene to Pliocene Western Cascades, and the Quaternary High Cascades, which overlies, and is east of, the Western Cascades (fig. 1). Both arcs are calc-alkaline and are characterized by voluminous mafic lava flows (mostly basalt to basaltic andesite compositions) and scattered large stratovolcanoes of mafic andesite to dacite compositions. Silicic volcanism is relatively uncommon. Quartz diorite to granite plutons are exposed in more deeply eroded parts of the Western Cascades Arc (for example, Mount Rainier area and just north of Mt. St. Helens, fig. 1).

Hydrothermal alteration is widespread in both Tertiary and Quaternary igneous rocks of the Cascades arcs. Most alteration in the Tertiary Western Cascades Arc resulted from hydrothermal systems associated with small plutons, some of which formed porphyry copper and related deposits, including copper-rich breccia pipes, polymetallic veins, and epithermal gold-silver deposits (fig. 1). Hydrothermal alteration also is present on many Quaternary stratovolcanoes of the High Cascades Arc. On some High Cascades volcanoes, this alteration resulted in severely weakened volcanic edifices that were susceptible to failure and catastrophic landslides. Most notable is the sector collapse of the northeast side of Mount Rainier that occurred about 5,600 yr. B.P. This collapse resulted in formation of the clay-rich Osceola Mudflow that traveled 120 km down valley from Mount Rainier to Puget Sound covering more than $200 \mathrm{~km}^{2}$ (fig. 2).

This field trip examines several styles and features of hydrothermal alteration related to Cenozoic magmatism in the Cascades arcs. The morning of the trip will examine the White River altered area, which includes high-level alteration related to a large, early Miocene magmatic-hydrothermal system exposed about $10 \mathrm{~km}$ east of Enumclaw, Washington (figs. 1 and 3). Here, vuggy silica alteration is being quarried

\footnotetext{
${ }^{1}$ U.S. Geological Survey, Menlo Park, California. ${ }^{2}$ U.S.Geological Survey, Vancouver, Washington. ${ }^{3}$ Weyerhauser Company, Federal Way, Washington. ${ }^{4}$ Tucson, Arizona.
}

for silica and advanced argillic alteration has been prospected for alunite. Clay-filled fractures and sulfide-rich, fine-grained sedimentary rocks of hydrothermal origin locally are enriched in precious metals. Many hydrothermal features common in high-sulfidation gold-silver deposits and in advanced argillic alteration zones overlying porphyry copper deposits (for example, Gustafson and Hunt, 1975; Hedenquist and others, 2000; Sillitoe, 2000) are exposed, although no economic base or precious metal mineralized rock has been discovered to date. The afternoon will be spent examining two exposures of the Osceola Mudflow along the White River. The Osceola Mudflow contains abundant clasts of altered Quaternary rocks from Mount Rainier that show various types of hydrothermal alteration and hydrothermal features. The mudflow matrix contains abundant hydrothermal clay minerals that added cohesiveness to the debris flow and helped allow it to travel much farther down valley than other, noncohesive debris flows from Mount Rainier (Crandell, 1971; Vallance and Scott, 1997).

The White River altered area is the subject of ongoing studies by geoscientists from Weyerhaeuser Company and the U.S. Geological Survey (USGS). The generalized descriptions of the geology, geophysics, alteration, and mineralization presented here represent the preliminary results of this study (Ashley and others, 2003). Additional field, geochemical, geochronologic, and geophysical studies are underway.

The Osceola Mudflow and other Holocene debris flows from Mount Rainier also are the subject of ongoing studies by the USGS (for example, Breit and others, 2003; John and others, 2003; Plumlee and others, 2003, Sisson and others, 2003; Vallance and others, 2003). Studies of hydrothermal alteration in the Osceola Mudflow are being used to better understand fossil hydrothermal systems on Mount Rainier and potential hazards associated with this alteration.

\section{Overview of Field Trip and Field Guidebook}

This one-day trip has five stops, the first three are in the White River altered area and latter two are in the Osceola Mudflow (fig. 4). The five stops are: Stop 1-Superior silica quarry, Ash Grove Cement Co.; Stop 2-Taugow breccia pipe; Stop 3-Scatter Creek silica quarry, James Hardie Building Products, Inc.; Stop 4-Osceola Mudflow near Greenwater; and Stop 5-Osceola Mudflow in the Corliss gravel quarry.

The first part of the guidebook contains a short road log from Enumclaw through the White River altered area and along the White River to Greenwater. 
The second part of the guidebook contains short chapters on the geologic setting of the White River altered area, the history of economic geology in the area, general features of hydrothermal alteration in the area, geophysical features of the altered area, and geochemistry of the alteration. These chapters are followed by detailed descriptions of the three field trip stops in the White River altered area.

The third part of the guidebook describes general features of the Osceola Mudflow and a preliminary study of hydrothermal alteration in the mudflow. These sections are followed detailed descriptions of the two field trip stops in the Osceola Mudflow.

\section{Acknowledgments}

We want to thank Weyerhaeuser Company for access to the Superior and Scatter Creek silica quarries, Scott Corliss of Corliss Resources for access to the Corliss gravel quarry, Denis Johnson of Weyerhaeuser for computer graphics, Steve Box for unpublished field data, and Robert Oscarson for help with the SEM. Reviews of the field guide by Ted Theodore and Don Singer were very helpful.

\section{Road Log from Enumclaw to the White River Altered Zone and the Osceola Mudflow along the Lower White River, Washington}

Elapsed

mileage

0.0 Intersection of Washington State Highways 164 and 410. Reset odometer to 0.0. Turn left onto Washington State Highway 410 and travel east.

1.1 Gravel quarry on left.

1.5 Corliss gravel quarry on left. We will return to the Corliss quarry this afternoon for Stop 5 to look at the Osceola Mudflow. The quarry produces sand and gravel from glacial kame terraces that were banked against the west edge of the cascade Range during Pleistocene glaciation.

3.5 The "410" aggregate quarry on left. Andesitic lava flows of the Fifes Peak Formation are quarried for crushed rock.

5.0 Mud Mountain Road on right. Road runs to the Mud Mountain Dam, a U.S. Army Corps of Engineers flood control dam. The dam was authorized by Congress in 1936 after the White River flooded in December 1933 devastating Tacoma and other parts of the Puget Sound lowlands. World War II delayed construction of the dam, which was finally completed in 1948.

6.4 Intersection with Scatter Creek Road on left. Turn left and pass through gate onto private timber company lands.

7.1 Denny-Renton quarry on left. The quarry produced small amounts of silica prior to 1936 and after World War II. More recently, the quarry has been backfilled by large blocks of silicified rock from the Superior (Ash Grove) quarry.

(

Stop 2, Taugow. See detailed description of this stop below. The rocky knob to west with clump of trees is silicified andesitic lapilli tuff. Superior quarry is in middle distance to the left (west-southwest) of this knob. Examine this knobby outcrop and the low roadcuts back down the road.

On clear days, a $360^{\circ}$ panorama of the White River altered area and the surrounding region is visible from the top of Taugow: glacier-covered Mount Rainier is at $\mathrm{S} .20^{\circ} \mathrm{E}$. The peak to due south is composed of the Pleistocene basalt of Canyon Creek that unconformably overlies the late Oligocene to early Miocene Fifes Peak Formation. The hill below in the middle distance is entirely altered; the outcrops are silicified and significant amounts of silicified rock have been delineated for possible future mining for silica.

To the west beyond the silicified knob is the lower White River Valley with buttes composed of Fifes Peak Formation in the distance. Enumclaw lies in the lowlands beyond these buttes.

The skyline to the north and northeast with the radio towers is Grass Mountain, which was mapped by Tabor and others (2000) as the Oligocene Ohanapecosh Formation. The slope in the middle distance is porphyritic andesite of Fifes Peak Formation. This area marks the northern edge of the White River hydrothermal system. Strands of the White River Fault Zone trend west-northwest through the terrain between this slope and Grass Mountain, juxtaposing the Fifes Peak Formation against the older Ohanapecosh Formation.

To the east is the White River Valley and the Naches Pass area is on the skyline. To the southeast across White River, the altered area continues. The cliff with the trees on top bounding a clear cut, trending downhill to the west, is another major silicified 
zone. Exploration for alunite in the 1940s was in an area to the left of this silicified zone.

Clearwater Creek is at S. $45^{\circ}$ E. The Fifes Peak Formation is exposed in Clearwater Creek canyon.

The upland areas east of Clearwater Creek are occupied by rhyolite and rhyolite tuff units of Clear West Peak. These rocks have been interpreted as being related to a caldera (McCulla, 1986).

Turn vehicles around and drive back down road.

11.9 Intersection with main road. Turn left.

12.6 Stop 3, entrance to Scatter Creek (James Hardie) quarry. See detailed description of the quarry below.

After tour of the Scatter Creek quarry, turn vehicles around and drive back down main road toward the paved road.

16.0 Intersection with Washington Highway 410. Turn left up the White River Valley. For next 10 miles, the road passes in and out of Fifes Peak Formation andesites and glacial deposits. Hydrothermal alteration related to the White River hydrothermal system ends after about 3.5 miles.

27.0 Cross the White River Fault Zone, a major NW-striking high-angle fault that juxtaposes Fifes Peak Formation andesite on the south against well-bedded andesite to dacite breccia, volcaniclastic sedimentary rocks, and locally abundant altered basalt and andesite flows of the somewhat older Ohanapecosh Formation.

27.5 Greenwater.

28.5 Fire station on left side of road.

28.8 Gravel road on right side of road to private houses. Park along the highway just past the gravel road.

Stop 4, Osceola Mudflow along White River. Find a trail parallel to the highway and walk about 50 feet west. Find a place to drop off the high terrace down to river level. Continue west about 100 feet to the outcrop right at river level. See detailed description of the outcrop below.

Return to vehicles, Turn around and drive back down Highway 410 toward Enumclaw.

41.6 Scatter Creek Road on right. Continue west on Highway 410 to the Corliss quarry.

46.5 Stop 5, Osceola Mudflow in the Corliss gravel quarry. See detailed description of the Corliss quarry below. End of road log.

\section{Part 1: The White River Altered Area}

\section{Geology of the White River Altered Area}

The White River altered area is located in the western Cascade Range 8 to $15 \mathrm{~km}$ east-southeast of Enumclaw, Washington. It comprises two adjacent areas of intensely altered volcanic rocks, one covering about $20 \mathrm{~km}^{2}$ on the north side of the White River, and a second covering about $3 \mathrm{~km}^{2}$ on the south side of White River. Alteration is likely continuous between these areas beneath surficial deposits in the White River Valley.

Bedrock in the area has been included in the Fifes Peak Formation by Tabor and others (2000) and McCulla (1986) (fig. 4). It consists mainly of porphyritic basaltic andesite and andesite flows and breccias (fig. 5). The typical porphyritic rock contains plagioclase, clinopyroxene, and orthopyroxene phenocrysts. Many outcrops in the altered area north of the White River show relict fragmental textures, and locally show compaction or eutaxitic structures, suggesting that the original rocks were tuffs and tuff breccias (fig. 6). These rocks are shown as a separate subunit of the Fifes Peak by Tabor and others (2000) (fig. 4). This subunit was interpreted by McCulla (1986) as outflow facies rhyolite tuff related to a caldera located about $10 \mathrm{~km}$ to the southeast in the Clearwater River drainage. Detailed mapping in the altered area has shown that this unit also may contain rhyolite or dacite flows, possibly part of a local flow-dome complex (fig. 7; G. Heinemeyer and G. Newport, unpub. data, 2003), and sparse felsic dikes.

The age range of the Fifes Peak Formation in the Snoqualmie Pass 30 x 60 minute quadrangle is about 20-24 Ma (Tabor and others, 2000). Only two samples of the Fifes Peak andesite in the vicinity of lower White River have been dated isotopically, yielding $\mathrm{K}-\mathrm{Ar}$ ages of $24.1 \pm 0.8$ and about 21.5 Ma (Tabor and others, 2000; Weyerhaeuser Co., unpub. data, 1994). Intracaldera rhyolite to the south at Clear West Peak, which is thought to be related to the extracaldera unit, has been dated at about $22 \mathrm{Ma}$ (Mattinson,1977).

The White River Fault Zone is a major fault zone that crosses the Cascade Range in the vicinity of Naches Pass, then follows the Greenwater and White Rivers in a west-northwesterly direction, passing 2 to $3 \mathrm{~km}$ north of the northern part of the altered area (fig. 4; Tabor and others, 2000). Rocks north of the White River Fault are mapped as part of the Ohanapecosh Formation by Tabor and others (2000). The Ohanapecosh consists of highly altered, well-bedded andesite to dacite breccia, volcaniclastic sedimentary rocks, and locally abundant altered basalt and andesite flows. It is somewhat older than the Fifes Peak, and it is thought to unconformably underlie the Fifes Peak Formation. Tabor and others (2000) also show a fault in the Clearwater River valley that strikes north-northwest into the altered area (figs. 4 and 8).

Quaternary surficial deposits are extensive in the lower White River area. They include glacial deposits and mudflows from Mount Rainier. Between the two altered areas, the bottom of the valley of the White River is relatively flat and more than $1 \mathrm{~km}$ wide; it broadens westward to a width of 7 to 8 $\mathrm{km}$. This low-lying area is underlain by glacial deposits of the Vashon stage of Fraser glaciation. Although most exposures of glacial material in this area have been mapped as undivided Vashon drift (Tabor and others, 2000), till, kame terrace, and recessional outwash deposits have been recognized.

Alpine glacial deposits, including till and outwash, locally mantle bedrock on the sides of the White River Valley. 
Tabor and others (2000) show a relatively large area of such deposits occupying the drainage area of Scatter Creek to the northwest of the larger altered area.

The low-lying glacial deposits are mantled by laharic deposits originating from Mount Rainier. The Osceola Mudflow (Crandell, 1971; Vallance and Scott, 1997) is the most extensive of these deposits.

\section{Economic Geology of the White River Altered Area-Historical Perspective}

According to Callaghan (1940) and Huntting (1955), silicified rock of the White River area was prospected for gold in the late 1800s. Two adits, one about $100 \mathrm{~m}$ long, were driven near the White River just south of the Superior quarry. A stamp mill was erected in about 1890 to mill the ore, but it was soon abandoned. Assays were said to range from about 0.03 to $0.07 \mathrm{oz} \mathrm{Au} /$ ton. In the late $1920 \mathrm{~s}$, alunite-bearing rock, initially assumed to be clay, was exposed by the White River Logging Company in cuts made in the course of constructing a logging railway. Alunite was identified in the early 1930s, and subsequently the Kalunite Company of Salt Lake City, Utah, explored the area for alunite by drilling and trenching. Some public lands within the altered area were explored by the Washington Division of Mines and Geology. Exploration done in the late 1930s and early 1940s yielded estimated reserves of $1,140,000$ tons of rock containing more than 20 percent alunite (Livingston, 1971; Kelly and others, 1956).

The only commodity exploited to date in the White River altered area is silica. Although not mentioned in reports on the alunite exploration, silica was produced by the DennyRenton Clay and Coal Co. from a small quarry near the west edge of the northern altered area (Denny-Renton quarry, fig. 8) some time before 1936 (Glover, 1936; Valentine, 1960). After World War II, Manufacturers Mineral Co. operated this quarry. Another small quarry located just north of Washington Highway 410 in Section 7 (T.19 N., R. 8 E.) on the south flank of Quarry Hill (fig. 8) was operated by Superior Portland Cement, Inc. in 1948 (Valentine, 1960, described therein as in R. 7 E.). This quarry also is known informally as the ASARCO quarry, because reportedly silica from this site was used as flux by the ASARCO smelter at Tacoma.

Recent quarry operations include the Superior pit, operated by Ash Grove Cement Co., which was started in 1987, and the Scatter Creek quarry operated by James Hardie Building Products, Inc., started in 1999 (fig. 8). Features of these active quarries are described in detail in this field guide.

Weyerhaeuser Company began exploration for base and precious metals in the White River hydrothermal system in 1986. Work done to date includes geochemical analysis of cuttings from many blast holes in and around the active silica pits, rotary drill holes to average depths of about $125 \mathrm{~m}$ in the large areas of silicification, a soil geochemical survey of selected areas both north and south of White River, periodic detailing mapping of the Superior and Scatter Creek silica quarries, isotopic dating, and recently, an IP survey north of White River and modeling of existing USGS geophysi- cal data. Preliminary results of this work and other on-going geophysical and geochemical investigations are described in this guide.

\section{Hydrothermal Alteration and Mineralization in the White River Area}

\section{Introduction}

The White River altered area consists of intensely altered rocks that are exposed across an area covering about $25 \mathrm{~km}^{2}$ on both sides of the White River near its confluence with the Clearwater River (fig. 8). Most alteration is exposed on the northwest side of the White River, and this guidebook focuses on a reconnaissance study of hydrothermal alteration in this area. The White River altered area displays many characteristic features that are associated with quartz-alunite (high-sulfidation) gold deposits (for example, Ransome, 1909; Steven and Ratte, 1960; Arribas, 1995; Hedenquist and others, 2000) and with the upper parts of porphyry copper-gold deposits (for example, Sillitoe, 2000).

\section{Previous and Present Studies}

McCulla (1986) described general alteration features and showed the distribution of some key alteration minerals in the White River altered area. Reconnaissance mapping by Weyerhaeuser Co. (1996) distinguished areas of argillic and advanced argillic alteration and silicification from unaltered and propylitized rocks (fig. 8). They performed a limited number of x-ray diffraction (XRD) analyses confirming their alteration types. The USGS has analyzed about 100 samples widely distributed across the north side of the White River altered area using infrared spectrometry (PIMA) (fig. 8, table 1). The sample density is inadequate to define regional-scale alteration zoning, if present, but analysis of these samples confirms the general types of alteration and identifies some previously unknown alteration minerals. Additional petrographic, XRD, geochemical, and geochronological studies of these samples are underway.

\section{Description of Hydrothermal Alteration}

Hydrothermal alteration on the north side of the White River altered area consists of two large bodies of massive silica \pm alunite that presently are being mined for silica, as well as numerous other bodies of silica (fig. 8). The silica bodies consist of vuggy silica alteration of andesite lava flows and breccias, pyroclastic rocks, and hydrothermal breccias that have been overprinted by subsequent stages of hydrothermal brecciation and chalcedonic silica veins and vug fillings (table 2). The silica bodies define two large zones of intense alteration where alkalis and alumina have been leached leaving a residual rock with greater than 95 weight percent silica. One silica body trends east-west and extends for about $5.5 \mathrm{~km}$ and another trends northeast for about $7 \mathrm{~km}$. Bordering the zones of silica are areas of low relief and limited outcrops of argillic 
and advanced argillic alteration containing kaolinite, dickite, alunite, illite, and locally, pyrophyllite (fig. 8). The distribution and geochemistry of the silica bodies have been documented during exploration, development, and mining of the silica bodies. There is less information on the extent and geochemistry of the argillic and advanced argillic alteration that borders the silica bodies. The size, continuity, and intensity of silicification and advanced argillic alteration are comparable to other large acid-sulfate systems that are associated with high-sulfidation gold-silver deposits and with porphyry copper-gold mineralization.

The acid-sulfate alteration formed in andesite flows and breccias assigned to the Oligocene to early Miocene Fifes Peak Formation, and in the Superior quarry, an intermediate composition (dacite?) flow or flow dome (fig. 7). The latter possibly is correlative with the rhyolite of Clear West Peak, and bedded tuffs and tuff breccias assigned as a rhyodacite tuff member of the Fifes Peak Formation by Tabor and others (2000) (figs. 4, 6, and 8). Because of the intensity of the acid leaching, the original composition and primary textures of many volcanic rocks are not discernable. In the Superior and Scatter Creek quarries, vuggy silica alteration locally contains numerous small vugs with morphology typical of plagioclase and pyroxene phenocrysts in the andesite flows in the Fifes Peak Formation (fig. 9). Other areas consist of massive, finegrained silica that may represent alteration of aphyric glassy volcanic rock. In the southwest part of the Superior quarry, a flow-banded volcanic rock of intermediate composition has relict devitrification layers and contains xenoliths of another intermediate composition volcanic rock. Sparse felsic dikes are present in both the Scatter Creek and Superior quarries and on Taugow.

The advanced argillic alteration consists of massive zones of residual silica bordered by alteration assemblages composed of kaolinite, dickite, alunite, pyrophyllite, and pyrite (fig. 8, table 1). Illite-, montmorillonite-, and chloriterich argillic and propylitic alteration is present outside the zone of advanced argillic alteration, but is poorly documented because of poor exposure. Residual vuggy silica alteration commonly displays relict voids developed after phenocrysts and (or) pumice clasts. Enargite and pyrite are present within the vuggy silica rock and in hydrothermal breccias, but for the most part, the sulfide minerals are oxidized and leached at present levels of exposure in the mines. Casts of pyrite also contribute to the vuggy texture of the residual silica. In the Scatter Creek quarry, fine-grained hematite replaces the sulfide minerals and gives the rock a dark gray color. Locally in the silica deposits, voids are not present and the silica is massive with little remnant texture. The massive nature of the silica may in part reflect the massive nature of the original rock, as well as late-stage deposition of hydrothermal silica that filled voids and fractures. Late-stage deposition of hydrothermal silica and sulfide minerals locally shows sedimentary textures and horizontal banding (see section on the Superior quarry below). The silica ranges from white chalcedonic silica to black chalcedony with darker colors reflecting the presence of sulfide minerals and (or) hematite replacement of sulfide minerals.

\section{Structural Control of Acid-Sulfate Alteration}

Residual vuggy silica alteration typically is structurally controlled (for example, Ransome, 1909; Steven and Ratte, 1960). Elongation of the silica bodies in the northern part of the White River altered area (fig. 8) suggests that major structural controls are east-northeast- and east-striking faults. In addition, some suggestion is present that silicification along the edges of the White River hydrothermal system may follow minor radial structures developed outward from hydrothermal and perhaps local volcanic vents. However, few structures controlling vuggy silica alteration are obvious in either the Superior or Scatter Creek quarries. On the north side of the Scatter Creek quarry, a prominent silicified ridge of vuggy silica alteration strikes $\mathrm{N} .10^{\circ} \mathrm{W}$. The ridge is comprised of vuggy silica alteration developed in pyroclastic rocks and porphyritic andesites of the Fifes Peak Formation, which are cut by numerous, irregular hydrothermal breccia bodies. Another narrow silicified rib of vuggy silica strikes N. $70^{\circ} \mathrm{E}$. and dips $75^{\circ} \mathrm{NW}$. The vuggy silica alteration here is bordered by narrow zones of alunitic and illitic alteration (fig. 10; also see section on the Scatter Creek quarry below).

\section{Age of Hydrothermal Alteration}

Isotopic ages of alunite from the advanced argillic alteration range from 20.4 to 23.5 Ma (McCulla, 1986; Weyerhaeuser Co., 1996). The youngest age, $20.4 \pm 0.1 \mathrm{Ma}$, is from Cady Hill (fig. 8) and determined by Ar-Ar methods. Alunite from a drill hole near the Superior quarry has a $\mathrm{K}-\mathrm{Ar}$ age of 21.0 $\pm 0.9 \mathrm{Ma}$, and alunite from Taugow has a K-Ar age of $22.3 \pm 0.9 \mathrm{Ma}$. Alunite from south of the White River (Bridge Camp alunite, fig. 8) has a K-Ar age of 23.5 $\pm 1.1 \mathrm{Ma}$. We are in the process of dating several additional alunite samples using $\mathrm{Ar}-\mathrm{Ar}$ techniques. It is likely that the entire area of advanced argillic alteration formed from the same hydrothermal system.

\section{Inferred Environment of Hydrothermal Alteration}

The advanced argillic alteration at White River formed from disproportionation of magmatic $\mathrm{SO}_{2}$ to $\mathrm{H}_{2} \mathrm{~S}$ and $\mathrm{H}_{2} \mathrm{SO}_{4}$ during condensation of a magmatic vapor plume (Rye and others, 1992; Stoffregen, 1987; Arribas, 1995), as indicated by mineral assemblages (table 1), types of silicic alteration (table 2), and reconnaissance stable isotope data in McCulla (1986). The acid condensate leaches most major and minor elements from the host rock leaving residual silica and forming zones of alunite and kaolinite (or pyrophyllite at higher temperatures), illite, montmorillonite, and propylitic alteration progressively outward from the residual silica core. This alteration zoning results from progressive neutralization and increasing $\mathrm{pH}$ of acidic magmatic-hydrothermal fluids due to rock buffering outward from fluid conduits (figs. 10 to 12; also see description of the Scatter Creek quarry). In this magmatic-hydrothermal environment, transport of rare earth and other elements, such as $\mathrm{F}, \mathrm{Cl}$, Ti, and $\mathrm{P}$, leads to formation of minerals, such as zunyite, woodhouseite, svanbergite, crandellite, and rutile-anatase, that 
may occur in the zone of alunite-kaolinite alteration. Elevated concentrations of $\mathrm{F}$, as much as 0.75 weight percent, and $\mathrm{TiO}_{2}$, as much as 3.8 weight percent, are present in the advanced argillic alteration at the Superior quarry (fine-grained rutile crystals have been observed in the Superior quarry and on Cady Hill). Zunyite $\left(\mathrm{Al}_{13} \mathrm{Si}_{5} \mathrm{O}_{20}(\mathrm{OH})_{16} \mathrm{~F}_{2} \mathrm{Cl}\right)$ has been identified by PIMA in one sample collected about $500 \mathrm{~m}$ northwest of the Scatter Creek quarry (fig. 8). Gallium concentrations are elevated in alunite-kaolinite alteration peripheral to the zone of vuggy silica alteration in the Superior quarry, as much as $101 \mathrm{ppm}$, and depleted in vuggy silica alteration, less than 0.5 $\mathrm{ppm}$. The Ga enrichment is typical of that present in zones of alunitic alteration formed in the magmatic-hydrothermal environment in other high sulfidation gold-silver deposits (Rytuba and others, in press). High Au concentrations, as much as 1.7 ppm, are present in fault and fracture zones that formed late in the hydrothermal system. The Au-enriched fault breccias and fractures are filled with red clay consisting of montmorillonite \pm dickite and earthy hematite.

The acid-sulfate alteration in the White River area is inferred to have formed at shallow depths beneath the paleosurface on the basis of sedimentary textures formed during late-stage hydrothermal alteration and types of silicic alteration (fig. 11, table 2). Hydrothermal depositional textures and the presence of steam-heated acid-leached rocks in the Scatter Creek quarry (see section on the Scatter Creek quarry below) indicate that the present exposures reflect the upper part of the hydrothermal system. Similarly, bedded hydrothermal sediments in the Superior quarry also indicate very shallow levels of the exposure of the hydrothermal system (see section on the Superior quarry below). Alteration features and possible base- or precious-metal mineralization at greater depths are unknown, because exploration drilling has been limited to shallow (average 125-m-deep), vertical drill holes, mostly within the silica quarries.

\section{Geophysical Framework of the White River Altered Area}

\section{Regional Magnetic Anomalies}

Volcanic rocks are typically magnetic and produce distinctive magnetic anomalies. Therefore, intense and pervasive hydrothermal alteration of volcanic rocks and the concomitant destruction of magnetic minerals sometimes produce negative anomalies in low-altitude magnetic measurements. Thus, an investigation was initiated to examine existing aeromagnetic data from, and conduct ground-magnetic measurements in, the White River altered area.

Figure 13 shows aeromagnetic anomalies surrounding the White River altered area. These data were acquired by the USGS in 1997 as part of ongoing earthquake hazard investigations of the Puget Lowland (Blakely and others, 1999). Flight lines were flown north-south at a nominal altitude of $250 \mathrm{~m}$ above terrain, or as low as safely possible. Lines were spaced $400 \mathrm{~m}$ apart over the Puget Lowland, but were spaced $800 \mathrm{~m}$ over outlying regions, including the White River altered area.
Widely spaced tie lines were flown in the east-west direction to facilitate data processing.

Magnetic anomalies (fig. 13A) surrounding the White River altered area display short-wavelength, high-amplitude patterns characteristic of unmetamorphosed volcanic terrane (fig. 13B). The most pronounced magnetic anomalies are associated with volcanic rocks of the Miocene Fifes Peak Formation and the Oligocene Ohanapecosh Formation in the northeastern and south-central parts of the study area. The west-northwest-striking White River Fault Zone, which brings these two formations into contact, is evident in the aeromagnetic anomalies, and other anomalies with similar WNW trend are related to mapped structures. Aeromagnetic anomalies (fig. $13 A$ ) also display north-northeast trends, possibly indicating faults antithetic to the White River Fault Zone, although no ENE-striking faults are mapped in the region (fig. 13B)). The White River altered area is located near the intersection of WNW- and ENE-trending anomalies, perhaps reflecting structural control on the evolution of the hydrothermal system.

Magnetic anomalies in the immediate vicinity of the White River altered area may have implications for mineral resource evaluations. A small magnetic high (label A, fig. $13 A$ ) corresponds closely with intense acid-sulfate alteration, exposed silica bodies, and a large shallow zone of very high resistivity and high chargeability zone at depth (fig. 14; Weyerhaeuser Co., 2003). It seems unlikely that altered rocks exposed at the surface contribute significantly to the positive magnetic anomaly. The anomaly may reflect an underlying intrusive body possibly related to the hydrothermal evolution of the White River altered area.

A broad, polygonal-shaped magnetic low (label B, fig. 13A) is also difficult to explain on the basis of regional geologic mapping. Sharp gradients around the margins of the magnetic low suggest that its source lies near the topographic surface. The anomaly is underlain by Fifes Peak Formation, which includes rhyolite and rhyodacite tuff. Such rocks commonly have low magnetizations, but exposures of these rocks elsewhere in the study area do not show pronounced aeromagnetic lows. The zone of intense acid sulfate alteration overlaps the magnetic low on its southeastern margin (fig. 13), suggesting that the anomaly may be caused by the destruction of magnetite during alteration of volcanic rocks. If so, the lateral extent of the magnetic low would permit mapping the lateral extent of intense alteration. Both anomalies A and B were investigated in the field during the summer of 2003, and those preliminary results are discussed below.

\section{Regional Gravity Anomalies}

Figure 15 shows a comparison of aeromagnetic and gravity anomalies over the White River altered area. Such comparisons are facilitated by first converting aeromagnetic anomalies to pseudogravity anomalies (fig. 15A), a linear filtering operation that in effect replaces magnetization with density in one-to-one proportions (Blakely, 1995). The lack of any obvious correlation between pseudogravity (fig. 15A) and observed gravity (fig. 15B) throughout the White River study area demonstrates that variations in magnetization are 
not obviously linked with variations in density, a common observation in volcanic terrane.

A notable exception is present directly over the altered area. Gravity stations are rather sparse in this region, however, precluding detailed comparisons of gravity anomalies with geology and aeromagnetic anomalies. Nonetheless, a small positive gravity anomaly does lie partially within the altered zone, approximately corresponding with the positive aeromagnetic anomaly (label A, fig. 13A and 15A), thus adding support to the existence of a relatively shallow intrusion possibly associated with the White River hydrothermal system.

\section{Field Investigations}

Detailed field studies were conducted during the summer of 2003 to investigate the near-surface expression of aeromagnetic anomalies in the White River altered area. Studies included three ground-magnetic transects walked along logging roads using a portable cesium-vapor magnetometer. A base station was established on Taugow to simultaneously measure diurnal and transient fields, which were subsequently subtracted from the ground-magnetic profiles. In addition, the ground-magnetic measurements were judiciously edited to remove cultural artifacts and magnetometer dropouts. Magnetic susceptibility measurements also were made at 27 sites inside and outside the altered zone using a hand-held susceptibility meter.

As expected, susceptibility measurements (fig. 16A) show a clear correlation between extraordinarily weak magnetization and the exposed zone of intense silicification. This correlation transcends the original rock type, as altered andesite flows are just as low in susceptibility as altered pyroclastic rocks. The only exception to the correlation is a single site (label X, fig. 16A), where high susceptibility was found inside the altered zone. This site is located within a quarry excavated into a laterally restricted fresh basalt or andesite of apparent Fifes Peak age.

Figure $16 B$ shows magnetic intensity measured along one of the ground-magnetic transects. As expected, the general aspects of the ground-magnetic profile agree with the aeromagnetic data. Most notable, the western edge of the aeromagnetic high agrees closely with a sharp gradient in the groundmagnetic profile. Surprisingly, the dramatic destruction of magnetic minerals, evident in susceptibility measurements (fig. 16A), is not obviously reflected in either the aeromagnetic or ground-magnetic data. This suggests that the aeromagnetic and ground-magnetic anomalies originate from sources below the zone of alteration.

Although the source of the magnetic high is clearly not the altered volcanic rocks exposed at the surface, the source probably lies at relatively shallow depth. This is evident from the sharp magnetic gradient on the ground-magnetic profile (arrow, fig. 17). Using a simple graphical technique (Blakely, 1995, p. 238-239), it is estimated that the source of this gradient lies between 230 and $390 \mathrm{~m}$ depth. IP surveys conducted independently in the area show high resistivity diminishing and high chargeability increasing at depths consistent with an inferred magmatic source (fig. 14). It is predicted, therefore, that magnetite-destructive alteration lies entirely above these depths. Drill holes did not extend to these depths, however.

The pronounced aeromagnetic low to the west of the silicified zone (label B, fig. 13A) remains problematic. Several explanations are possible. (1) The anomaly is located over a region of relatively flat and subdued topography bounded on the north, south, and east by higher terrain. The possibility that the negative anomaly is caused by variations in aircraft altitude and terrain effects was considered, but modeling experiments using digital elevation models indicate that this is not the case. (2) The anomaly may reflect a subsurface extension of hydrothermally altered volcanic rocks, but the lack of correlation between ground-magnetic and aeromagnetic anomalies on the one hand and susceptibility measurements and silicified rock on the other makes that conclusion difficult to defend. (3) The magnetic low may be caused by a thick basin filled with relatively nonmagnetic glacial deposits. Such a basin should produce a negative gravity anomaly as well, but gravity measurements, although sparse, show a slight positive anomaly. (4) The magnetic low may be caused by reversely magnetized volcanic rocks that erupted during a time of reversed magnetic polarity. Future field studies and magnetic modeling experiments are planned to evaluate these alternative explanations.

\section{Geochemical Exploration Studies of the White River Altered Area}

Weyerhaeuser Company work has focused on geologic mapping and surface exploration sampling programs in specific areas, including working mine faces, and on detailed geochemical analysis of drill holes. Geochemical sampling has targeted zones of intense silicification, hydrothermal breccias, areas of outcrop, and locations with soil sample anomalies. Additionally, several, large reconnaissance-scale soil sample surveys have been completed. Areas with the highest sample density and most geochemical data include the Superior quarry area, the Scatter Creek quarry area, the Taugow area, the Quarry Hill area, and altered areas south of the White River (fig. 8).

Many trace elements in the White River altered area are elevated to varying degrees in the most siliceous areas. Anomalous elements include $\mathrm{Au}, \mathrm{As}, \mathrm{Cu}, \mathrm{Sb}, \mathrm{Bi}, \mathrm{Te}, \mathrm{Pb}, \mathrm{Zn}$, $\mathrm{Mo}, \mathrm{Hg}$ and Se. Statistical analysis of geochemical data and field observations suggest that in the Superior quarry hill area there may be two primary geochemical associations- $\mathrm{Cu}$ $\mathrm{As} \pm \mathrm{Te}$, probably related to enargite deposition in vuggy silica, and $\mathrm{Bi}-\mathrm{Sb}$-Te-Au-Mo-As related to hydrothermal veins and breccias.

Experience has shown that sampling of the highly leached surface exposures rarely produces geochemical results representative of the original trace element composition. In fact, samples from surface outcrops commonly are devoid of anomalous concentrations. Sampling of subsurface zones with abundant limonite or sulfide minerals commonly yields trace element contents several orders of magnitude greater than leached surface samples. Zones with elevated trace element contents commonly are present within 10 meters of the exist- 


\section{Field Guide to Hydrothermal Alteration in the White River Altered Area and in the Osceola Mudflow, Washington}

ing erosion surface. Although tentative, certain geochemical patterns have been recognized along with a distinct elemental suite. Anomalous trace elements present at the White River prospects and the patterns in which they are present are as follows:

\section{Gold}

Anomalous gold content, in excess of $100 \mathrm{ppb}$, was found in outcrop by numerous samplers in the 1970s and 1980s. Most of these samples were in the Superior quarry and Quarry Hill areas. High Au contents (500 to 1,800 ppb) do not tend to be present within silicified promontories. Rather, the highest concentrations have been found in the following settings:

1. Soil samples from depressions surrounded by silicification.

The best example is on the south face of Superior quarry hill area where a depression surrounded by vertical cliffs yielded soil samples with 1,600 ppb Au. Fill-in soil sampling defined the area and later rock chip sampling and shallow air-track drilling produced similar values.

2. Advancement of the Superior quarry allowed sampling along a strike length of 200 meters in a highly fractured zone trending $\mathrm{N} .70^{\circ} \mathrm{W}$. The fracture zone crosscuts silicification and did not crop out prior to mining. At each stage of mine advance, the gold contents increased, and Au contents in this structural zone are as much as $1,800 \mathrm{ppb}$. Associated with this zone are large pockets of white hydrothermal kaolinite and small amounts of manganese oxide.

3. During excavation of overburden prior to mining near the west end of the Superior quarry, Ash Grove uncovered a circular depression about $30 \mathrm{~m}$ in diameter. The depression had steep sides and a fracture pattern parallel to the steep faces, which dipped away in all directions. Excavation, which went to the current pit floor elevation, never intersected bedrock in the depression; however, abundant highly limonitic material was present. Two samples containing 500 and 900 ppb Au were collected along lower exposures within the depression. The depression also had highly anomalous concentrations of Te, Ba, Sb, $\mathrm{Bi}, \mathrm{Mo}, \mathrm{As}, \mathrm{Cu}, \mathrm{Zn}$, and Ag. This depression may mark a hydrothermal eruption crater.

4. Gold anomalies in soil samples suggest several linear trends as much as $400 \mathrm{~m}$ long and $15 \mathrm{~m}$ wide. Although $\mathrm{Au}$ anomalies are sometimes spatially associated with massive silicification, they are commonly adjacent to or cross in and out of silicified rocks in softer zones with abundant clay alteration that did not crop out prior to mining.

Observations in the Superior quarry hill area suggest that the gold anomalies are in softer fracture zones or in pipe-like structures cutting silicified rocks. These less resistant rocks typically were scoured out by glaciation and filled with glacial debris, which may make recognition by soil sampling difficult. Anomalous Au contents are present in both sulfide mineralbearing and oxidized, altered rocks.

\section{Silver}

Silver is uniformly low in the White River area. The highest Ag content in the Superior quarry hill area is $1.55 \mathrm{ppm}$ from a sample on the southwest flank of the hill near Washington Highway 410. Here, elevated Ag is associated with high Bi and $\mathrm{Sb}$ contents.

\section{Arsenic}

Elevated arsenic contents in excess of 300 ppm have been found in samples collected from numerous locations in the White River altered area. Enargite-bearing samples, areas with high limonite content, and sulfide zones beneath the most intensely leached capping tend to have the highest As contents. Maximum values commonly exceed 1,000 ppm. Anomalous As is commonly associated with anomalous amounts of $\mathrm{Cu}$, where enargite is likely the source mineral. However, some samples also contain low $\mathrm{Cu}$ contents and high As contents. Samples with low $\mathrm{Cu}$ contents generally are present in oxidized rocks.

\section{Copper}

Elevated copper contents are associated with the abundant limonite and sulfide mineral-rich zones within the strongly silicified areas. Concentrations in excess of $100 \mathrm{ppm}$ are common with maximum values greater than $12,000 \mathrm{ppm}$ (1.2 weight percent $\mathrm{Cu}$ ) in an enargite-bearing sample from the Superior quarry. The most anomalous $\mathrm{Cu}$ is in the Superior quarry hill area.

\section{Antimony}

Antimony contents beneath leached capping in the most siliceous core zones average about $25 \mathrm{ppm}$. Widespread values greater than $50 \mathrm{ppm}$ are common and maximum values are about 500 ppm. Most anomalous Sb is near the Superior quarry hill area, although areas of anomalous $\mathrm{Sb}$ also are present south of White River (Sec. 10, T. 19 N., R. 8 E.), where several gossan samples have yielded high Sb contents. No drilling has been conducted in these areas.

\section{Mercury}

High mercury contents are present locally in silicified rocks. Samples with greater than $500 \mathrm{ppb} \mathrm{Hg}$ are common and anomalies from $1,000 \mathrm{ppb}$ to greater than $5,000 \mathrm{ppb}$ are present in the more intensely silicified and pyritized areas.

\section{Bismuth, Tellurium and Selenium}

Highly anomalous bismuth, tellurium and selenium contents have been found in the Superior quarry hill area. The most anomalous values for each element are about 200 ppm Se, 200 ppm Te, and 900 ppm Bi. Higher Bi and Te contents commonly are associated with high $\mathrm{Sb}$ contents. 


\section{Molybdenum}

A strong molybdenum anomaly in drill holes and surface samples is present south of the Scatter Creek quarry. The area, bounded by Cady Hill, the east flank of Quarry Hill, and the Scatter Creek quarry has yielded anomalous Mo contents in surface samples and in two drill holes. Molybdenum contents in the drill holes commonly exceeded $100 \mathrm{ppm}$, and the highest Mo content was $750 \mathrm{ppm}$. These anomalies are present close to anomalous $\mathrm{Pb}$ and $\mathrm{W}$ (30-40 ppm) contents, but no other strong elemental associations were noted.

The Mo anomalies may reflect a deep source for the hydrothermal alteration and mineralization exposed on the surface. The near-surface Mo anomaly is coincident with an IP chargeability anomaly (fig. 14) and may be located over deep, porphyry style copper-gold-molybdenum mineralized rock (fig. 11). More work is needed to determine the significance of the anomalous molybdenum zone in this area.

\section{Stop 1: Superior (Ash Grove) Quarry}

The Superior (Ash Grove) silica quarry is located in the southwest part of the White River acid-sulfate alteration system (figs. 8 and 18). The massive silica bodies consist of vuggy silica that has been crosscut by several stages of hydrothermal breccias and overprinted by chalcedonic veining and quartz veining and vug filling. The hydrothermal breccias have been rebrecciated and subjected to continued acid leaching and vuggy silica development. Intense acid leaching of host andesite and dacite flows and tuffs of the Fifes Peak Formation by magmatic-hydrothermal fluids has resulted in the formation of vuggy silica rock with greater than 95 weight percent $\mathrm{SiO}_{2}$. Aluminum content is generally less than 0.5 weight percent $\left(\mathrm{Al}_{2} \mathrm{O}_{3}\right)$, and $\mathrm{Na}, \mathrm{K}, \mathrm{Mg}$ and $\mathrm{Ca}$ oxides are all less than 0.15 weight percent. Iron content as hematite and more rarely as pyrite in the silica bodies is variable ranging as high as 12 weight percent but more typically is less than 5 weight percent. Ti oxide content ranges from 0.6 to 1.6 weight percent. Mining for silica by the Ash Grove Cement Company is by open pit methods, and the silica is crushed and sized on site. The silica is used in the production of Portland cement. Bordering the silica body exposed in the quarry are areas of low relief and limited outcrops of advanced argillic alteration consisting of kaolinite and alunite and locally pyrophyllite (fig. 18).

The rocks in the Superior quarry are highly altered and it is commonly difficult to discern the original rock type (fig. 19). Massive and homogenous gray vuggy silica in the central and west part of the quarry contains voids where plagioclase and pyroxene phenocrysts have been leached from andesite flow rock (fig. 20). Pyrite and enargite (figs. 21 and 22) are present most commonly in the hydrothermal breccias, and also are present locally in the vuggy silica; however, at the present mine level, the sulfide minerals are mostly oxidized and leached leaving numerous voids. Hematite is the primary oxidation product of the sulfides and gives the vuggy silica its dark gray color.
In the southeast part of the quarry, bedded welded tuffs have been leached and altered to vuggy silica rock. The voids in the vuggy silica were developed from leaching of pumice and phenocrysts and are larger than those developed in the altered andesite flow rock. Layering within the tuff indicates that bedding is subhorizontal.

In the southwest part of the quarry, vuggy silica alteration is developed in a porphyritic intermediate composition rock (possibly dacite) and associated fragmental volcanic rocks. Exposures of altered flow-folded dacite are present on the steep scarp just south of the quarry (fig. 7). The dacite shows relict flow banding and has textural layers that are interpreted to be devitrification textures developed in glassy zones in the dacite (fig. 23). Xenoliths as much as several $\mathrm{cm}$ in length are present in the dacite. Vuggy silica alteration developed in the dacite and associated fragmental rocks contains larger voids and is less massive and homogenous as compared to vuggy silica alteration developed in andesite flow rock. Other areas in the pit consist of massive, fine-grained silica that may represent alteration of an aphyric glassy flow rock (fig. 24). Finegrained layering is commonly visible in rocks that have been silicified, and these rocks likely were bedded fine-grained tuffs and sedimentary rocks that are exposed in outcrops about 0.5 $\mathrm{km}$ north of the quarry (fig. 6).

Also in the steep face on the upper bench along the southwest side of the pit, a narrow, north-northeast striking, felsite porphyry dike cuts near horizontal flow foliated dacite. The dike cuts the center of the prominent hill and forms the point of highest elevation (fig. 25). This dike extends across the pit to the northeast. The fine-grained dike rocks are buff-white to tan in color and contain sparse 1-2 mm quartz phenocrysts. Dike margins commonly exhibit faint flow banding accentuated by weak limonite staining. The dike occasionally is cut by irregular, hairline quartz veins. Near its margins, it contained appreciable pyrite that is now oxidized. The dike, although completely silicified, appears to postdate most massive hydrothermal breccias in the Superior quarry; however, in the northern part of the pit, narrow hydrothermal breccia dikes cut and contain fragments of the dike. This indicates the complex and multiphase nature of the breccias and associated hydrothermal activity. The presence of the felsite porphyry dike is significant from several perspectives:

- It is situated in the center of some of the most massive and well-developed hydrothermal breccias;

- The dike is proximal to zones of abundant limonite and gossan that correspond to areas of pyritic hydrothermal sediments and associated hydrothermal vents;

- The dike forms the core of a north-northeast-trending zone that contains some of the highest $\mathrm{Au}, \mathrm{As}, \mathrm{Cu}$, and Bi contents;

- The dike may be a late magmatic feature related to a dacite dome in the Superior quarry area (figs. 7 and 23).

Multiple stages of veining and hydrothermal brecciation core the vuggy silica zones and silicified rocks in the quarry. The earliest stage consists of hydrothermal breccia and veins 
containing white chalcedonic silica (fig. 26). Locally large voids created during brecciation of the vuggy silica are filled with white chalcedony that forms a massive white rock with little or no texture. Later stages of veining and hydrothermal brecciation contain various colors of chalcedony ranging from tan (fig. 27) to black depending on the amount of sulfide minerals present and extent of oxidation of the sulfide minerals. Veins of gray chalcedony cut vuggy silica rock and locally develop a stockwork texture (fig. 28). Late stage hydrothermal deposition of silica and sulfide minerals commonly show sedimentary textures and horizontal banding indicating near-surface deposition of silica and sulfide minerals in hydrothermal vents (figs. 22 and 29).

In the southwest part of the quarry, a series of north-striking high-angle normal faults contain hematite-rich, clay-supported breccias and clay-filled fractures are present (figs. 30 and 31). Some clay zones are subhorizontal and likely reflect alteration of tuffs interbedded with the dacite flow (fig. 32). Gold contents as much as $1.7 \mathrm{ppm}$ are present in these fault and fracture zones. The clay minerals are montmorillonite \pm dickite. Sedimentary structures, such as graded and cross bedding, in these open fractures indicate near-surface deposition and that the level of exposure of the hydrothermal system is relatively shallow.

Detailed geochemical surveys of the silica bodies show that anomalous concentrations of $\mathrm{As}, \mathrm{Au}, \mathrm{Bi}, \mathrm{Cu}, \mathrm{Ga}, \mathrm{Hg}$, Mo, $\mathrm{Sb}, \mathrm{Se}, \mathrm{Te}$, and $\mathrm{F}$ are present locally. Elevated concentrations of $\mathrm{F}$, as much as 0.75 weight percent, and $\mathrm{TiO}_{2}$, as much as 3.8 weight percent are present in the advanced argillic alteration. Fine-grained rutile is present locally. In areas where $\mathrm{Au}$ is anomalous, higher concentrations of $\mathrm{Sn}$ and $\mathrm{W}$ also are present. This geochemical suite is typical of that associated with high-sulfidation gold deposits that are associated with porphyry $\mathrm{Cu}-\mathrm{Au}$ systems (for example, Sillitoe, 2000).

\section{Stop 2: Taugow}

Taugow, a hill midway between the Superior and Scatter Creek quarries, is named for the Taugow VABM marker near the top of the hill (figs. 8 and 33). Rocks exposed on Taugow include strongly altered tuff and tuff breccia cut by a narrow felsic dike and by hydrothermal breccias. Most pyroclastic rocks exposed are silicified or strongly altered alunitically. This brief stop will examine these hydrothermal features. In addition, if the weather is clear, this stop affords a $360^{\circ}$ panorama of the White River altered area and Mount Rainier (see road log).

From the parking area (landing at end of road), the small knob to the west consists of alunitically-altered tuff and tuff breccia containing relatively coarse-grained, pink-colored alunite (fig. 34). Alunite from here has been dated at $22.3 \pm 0.9 \mathrm{Ma}$ by $\mathrm{K}-\mathrm{Ar}$ methods (Weyerhaeuser Co., 1996), and a ${ }^{40} \mathrm{Ar} /{ }^{39} \mathrm{Ar}$ date is in progress.

The north side of the road cut just before the end of the road exposes silicified, well-bedded tuff breccia (fig. 35) intruded by a narrow ( 2 to 3 -cm-wide) fine-grained, quartzphyric felsic dike (fig. 36) and cut by hydrothermal breccias. This dike and a similar dike mapped in outcrops on the lower southwest flank of Taugow are examples of only a few dikes that have been recognized in the White River altered area. Bedding in the tuff is about N. $10^{\circ}$ E. $20^{\circ} \mathrm{SE}$. To the south across the road from the tuff breccia, hydrothermal breccia is well exposed (fig. 37). The matrix-supported breccia contains a heterogeneous mixture of subangular blocks as much as 50 $\mathrm{cm}$ wide, including flow-banded lavas and (or) well bedded tuffs, felsite, and porphyritic andesite. The blocks are silicified and include vuggy silica alteration. The breccia matrix consists of fine-grained silica and hematite. The hematite probably replaces sulfide minerals.

\section{Stop 3: Scatter Creek (James Hardie) Silica Quarry}

The Scatter Creek (James Hardie) silica quarry produces high purity silica, greater than 97 weight percent $\mathrm{SiO}_{2}$, from leached and silicified volcanic rocks of the Fifes Peak Formation and cross-cutting hydrothermal breccias (fig. 38). Aluminum content of the silicified rock is generally less than 0.5 weight percent $\left(\mathrm{Al}_{2} \mathrm{O}_{3}\right)$, and $\mathrm{Mg}, \mathrm{Ca}, \mathrm{Na}$, and $\mathrm{K}$ oxides are less than 0.02 weight percent. Residual Ti oxide is present at as much as 0.8 weight percent and Fe oxide as hematite is variable but generally less than 0.5 weight percent. Silica is mined by open pit methods and crushed and sized on site (fig. 39) for shipment to James Hardie Building Products, Inc., for production into fiber cement-based external siding and backer board known as Hardibacker. Silica is stockpiled on site and mining is episodic, occurring when stockpiles are depleted.

Alteration in the Scatter Creek quarry consists of pervasive leaching of porphyritic andesite flows and pyroclastic rocks to form vuggy silica alteration (fig. 40). In the central part of the quarry, vuggy silica alteration is well developed in massive andesite flows and is characterized by voids from 2 to 4 $\mathrm{mm}$ in length formed from the leaching of plagioclase feldspar and pyroxene phenocrysts. The morphology of the leached phenocrysts is well preserved throughout most of the dark gray to black vuggy silica rock (fig. 41). Locally larger voids are present where leaching of clots of phenocrysts (glomeroporphyroclasts) has occurred. The large body of vuggy silica alteration in the central part of the quarry trends E-W and has elevated concentrations of $\mathrm{Ag}, \mathrm{As}, \mathrm{Au}, \mathrm{Cu}, \mathrm{Hg}, \mathrm{F}, \mathrm{Mo}, \mathrm{Se}, \mathrm{Sb}$ and Te. The highest concentration of Mo, as much as several hundred $\mathrm{ppm}$, is present in vuggy silica in the SE part of the quarry. Molybdenum contents in excess of $700 \mathrm{ppm}$ were encountered in drill holes just south of the Scatter Creek quarry. In the north-central part of the quarry, a rib of vuggy silica alteration about 1 meter wide was developed along a N.60-70 ${ }^{\circ}$ E. striking fault that localized the upward flow of acid magmatic-hydrothermal fluids (figs. 10 and 42). Bordering this vuggy silica is a zoned assemblage of advanced argillic alteration where plagioclase and pyroxene phenocrysts have been replaced by alunite and kaolinite, grading outward into zones of illite and montmorillonite/chlorite (fig. 43). This zoning was developed as a result of buffering of the acid fluids by the country rock as it moved outward from the fault (figs. 11 and 12).

Most pyrite and other sulfide minerals in the vuggy silica alteration have been oxidized to a depth of greater than 125 $\mathrm{m}$, and relict pods of sulfide minerals are only rarely present. 
Casts after pyrite are common, however, and indicate that as much as several weight percent pyrite was originally present. Fine-grained specular hematite is the primary oxidation product of pyrite and gives the vuggy silica its dark gray color. Within the upper few meters of the surface, hematite has been leached from the rock by surface weathering, and the resulting vuggy silica is white and distinctive from its generally black to gray color (fig. 44).

Multiple stages of hydrothermal breccias and quartz and chalcedonic veins cut the vuggy silica rock in and outside the quarry. An early stage of hydrothermal breccias cemented by white chalcedony and cut by white chalcedony silica veins is well developed in vuggy silica present in and outside the quarry (fig. 45). On the periphery of the quarry, vuggy silica alteration has been hydrothermally fractured and locally more strongly brecciated and the resulting fractures and open spaces have been filled by white chalcedony. Hydrothermal fracturing and rotation of blocks of vuggy silica during hydrothermal brecciation locally developed large voids, as much as $0.5 \mathrm{~m}$, that were filled with dense white chalcedony that now form massive bodies of white silica. A subsequent stage of hydrothermal breccias and veins containing tan (fig. 40) to dark gray chalcedony cut the early stage of white chalcedony veins. The later chalcedony veins and breccia contained fine-grained sulfides that have been oxidized to hematite (fig. 46), and the veins have elevated concentrations of $\mathrm{As}, \mathrm{Au}, \mathrm{Cu}, \mathrm{Hg}, \mathrm{F}, \mathrm{Mo}, \mathrm{Sb}, \mathrm{Se}$, and Te.

High-angle normal faults and fractures cut the vuggy silica alteration and are well exposed in the quarry. The most prominent fault zone is $3 \mathrm{~m}$ wide, strikes N. $10-45^{\circ} \mathrm{W}$. and dips $80^{\circ} \mathrm{SW}$. It is filled with clay-supported fault breccia. Red clay-filled fractures, similar to Au-bearing fractures in the Superior quarry, are present throughout the Scatter Creek quarry. They consist of montmorillonite \pm dickite and abundant hematite and are 1 to $12 \mathrm{~cm}$ wide (fig. 47).

An alteration zone of highly leached white rock consisting of cristobalite, opal, and kaolinite is present within a fault block in the central part of the quarry (fig. 48). This type of hydrothermal alteration is typical of alteration that forms in the steam-heated environment above the paleo-ground water table. In this environment, $\mathrm{H}_{2} \mathrm{~S}$ is oxidized by atmospheric oxygen to form sulfuric acid that leaches alkalis and aluminum from the rock leaving residual silica (for example, Schoen and others, 1974; Hedenquist, 1990). Because the alteration forms in a near-surface, low temperature environment, the residual silica is typically opal and cristobalite. The presence of steamheated acid-leach alteration indicates that the level of exposure of the hydrothermal system in the Scatter Creek quarry is relatively shallow (fig. 11 and table 2).

\section{Part 2: The Osceola Mudflow in the Lower White River}

\section{General Features of the Osceola Mudflow}

About 5,600 years ago, an eruption of Mount Rainier triggered an edifice (sector) collapse that caused the $3.8-\mathrm{km}^{3}$
Osceola Mudflow and coeval phreatic and pumiceous magmatic tephras. The phreatic tephras, like the Osceola Mudflow, are clay-rich and contain hydrothermal minerals typical of acid-sulfate systems. Mineralogy and stratigraphy demonstrate the genetic link between the Osceola Mudflow and its tephra and suggests how the hydrothermal system might have influenced the eruption (Vallance and Scott, 1997; Vallance and others, 2003).

The Osceola Mudflow began as a water-saturated avalanche or a series of avalanches during phreatomagmatic eruptions at the summit of Mount Rainier. It filled valleys of the White River system north and northeast of Mount Rainier to depths of 80 to $150 \mathrm{~m}$, flowed northward and westward more than $120 \mathrm{~km}$, covered more than $240 \mathrm{~km}^{2}$ of the Puget Sound lowland, covered another $160 \mathrm{~km}^{2}$ under the water of Puget Sound and extended as much as $20 \mathrm{~km}$ under water (figs. 2 and 49).

Near Mount Rainier, deposits of the Osceola Mudflow cap ridges high above the Winthrop and Emmons Glaciers. Remnants also are present on top of Steamboat Prow and throughout the Inter Fork drainage basin. The homogeneity of these deposits, the lack of hummocky terrain within $10 \mathrm{~km}$ of the summit, and the apparent fluidity suggest that the avalanches which initiated the Osceola Mudflow mixed thoroughly within $2 \mathrm{~km}$ of their source and abruptly began to behave like an enormous water-saturated debris flow.

Mapping the upper limits (inundation limit) of the Osceola Mudflow along the steep-sided White River Valley between Mount Rainier and Mud Mountain, 75 km downstream, reveals that the peak-stage height of the mudflow attenuated sharply near the volcano then reached an equilibrium height downstream. In the Inter Fork Valley, deposits of the mudflow are present $400 \mathrm{~m}$ above the valley bottom. Five kilometers downstream, the inundation limit is $200 \mathrm{~m}$; farther downstream, it stabilizes, varies between $85 \mathrm{~m}$ and $140 \mathrm{~m}$, and averages about $100 \mathrm{~m}$. The decrease of the maximum inundation depth downstream by longitudinal spreading and by deposition was counteracted by the additional discharge from the West Fork $45 \mathrm{~km}$ downstream and by bulking of the flow through the incorporation of eroded sediment.

Mud and debris of the Osceola Mudflow that ran up onto Goat Island Mountain, about $10 \mathrm{~km}$ from Mount Rainier, and onto a ridge dividing the White and Greenwater Rivers, about $45 \mathrm{~km}$ downstream of Mount Rainier, allow the maximum velocity and peak discharge of the flow to be estimated at these two places (fig. 49). Clay-rich Osceola debris is present to an altitude of 2,054 $\mathrm{m}$ on Goat Island Mountain but not just up valley at an altitude of 1,944 $\mathrm{m}$ at the top of a low divide between Emmons Glacier and Fryingpan Creek. The debris on Goat Island Mountain suggests that the Osceola Mudflow ran up $110 \mathrm{~m}$. Using $\mathrm{v}=(2 g h)^{1 / 2}$, the velocity of the flow must have been at least $46 \mathrm{~m} / \mathrm{s}$. Taking a typical nearby cross-sectional area in the Main Fork valley of about 190,000 $\mathrm{m}^{2}$ suggests a discharge of approximately $8,000,000 \mathrm{~m}^{3} / \mathrm{s}$. If the velocity was the same about $10 \mathrm{~km}$ downstream in the West Fork valley, a typical cross-sectional area of about $80,000 \mathrm{~m}^{2}$ suggests a discharge of approximately 4,000,000 $\mathrm{m}^{3} / \mathrm{s}$ there and a simultaneous discharge of about $12,000,000$ $\mathrm{m}^{3}$. Similarly, at the confluence of the West and Main Forks 
of the White River, mud and debris of the West Fork flow that ran up about $18 \mathrm{~m}$ onto a ridge dividing the White and Greenwater Rivers (fig. 49) allow a maximum velocity of 19 $\mathrm{m} / \mathrm{s}$ to be estimated. Taking a typical nearby cross-sectional area in the West Fork valley of at least 70,000 $\mathrm{m}^{2}$ suggests a discharge of approximately $1,300,000 \mathrm{~m}^{3} / \mathrm{s}$. If the simultaneous discharge along the Main Fork was as large, then the total discharge of the Osceola Mudflow near the confluence of the two forks of the White River would have been about $2,600,000 \mathrm{~m}^{3} / \mathrm{s}$.

When it encountered a narrow gorge of the White River at Mud Mountain that is only $300 \mathrm{~m}$ wide, the Osceola Mudflow spread out over glaciofluvial terraces of Vashon age that are as much as $110 \mathrm{~m}$ above the White River. As it continued westward, the mudflow poured over terrace scarps to form a spectacular pair of falls. The upper fall would have formed an arc more than $6 \mathrm{~km}$ wide and over $80 \mathrm{~m}$ high, and the second would have been more than $3 \mathrm{~km}$ wide and over $110 \mathrm{~m}$ high.

In the lowland, the Osceola Mudflow completely choked the channel of the White River, which in pre-Osceola time followed the relatively confined valley of South Prairie Creek southwestward to join the Puyallup River at Orting, then flowed northwestward across the drift plain into the Green River drainage (Crandell, 1963). When the White River reestablished normal flow, it flowed northwestward toward Auburn along the radically different course near the axis of the lahar lobe.

The Osceola entered the Duwamish and Puyallup embayments of Puget Sound via deltas at the mouths of the Green and Puyallup Rivers (fig. 49). Low gradients on the deltas caused the debris flow to pile as much as thicknesses of more than $20 \mathrm{~m}$ near Auburn and Sumner (Dragovich and others, 1994). Deposits are generally present only in the subsurface in the Duwamish and Puyallup Valleys. Wood-bearing, clayey, gravel-rich deposits at depths of 20 to 100 m northwest of Puyallup and north of Auburn show that the Osceola Mudflow retained its coherence and flowed more than $20 \mathrm{~km}$ under water.

Osceola Mudflow deposits comprise three facies. The axial facies forms normally graded deposits 1.5 to $25 \mathrm{~m}$ thick in lowlands and valley bottoms and thinner ungraded deposits in lowlands; the valley-side facies forms ungraded deposits 0.3 to $2 \mathrm{~m}$ thick that drape valley slopes; and the hummocky facies, interpreted before as a separate (Greenwater) lahar, forms 2-to-10-m-thick deposits dotted with numerous hummocks as much as $20 \mathrm{~m}$ high and $60 \mathrm{~m}$ in plan.

The Osceola Mudflow transformed completely from debris avalanche to clay-rich lahar within $2 \mathrm{~km}$ of its source because of the presence of large volumes of pore water and abundant weak hydrothermally altered rock within the preavalanche mass. A survey of clay-rich lahars suggests that the amount of hydrothermally altered rock in the pre-avalanche mass determines whether a debris avalanche will transform into a lahar or remain a largely unsaturated debris avalanche. The potential for transformation has important implications for hazard assessments because lahars are more mobile than debris avalanches, and therefore spread more widely and travel much greater distances down valley.

\section{Hydrothermal Alteration in the Osceola Mudflow}

Preliminary study of the Osceola Mudflow and other Holocene debris flows from Mount Rainier indicates that three major types of hydrothermal alteration were present on Mount Rainier prior to volcano collapse and formation of the debris flows (John and others, 2003)—(1) an intermediate argillic assemblage consisting of smectite-group clay minerals + pyrite \pm silica \pm barite \pm anhydrite/gypsum; (2) advanced argillic alteration consisting of kaolinite + opal/ chalcedony + pyrite/marcasite \pm alunite \pm pyrophyllite; and (3) jarositic alteration (jarosite + alunite + opal). Study of the matrix of the Osceola Mudflow where unaffected by postflow surficial weathering indicates that it contains abundant fine-grained pyrite (fig. 50), in addition to the high clay contents previously documented by Crandell (1971) and Vallance and Scott (1997). X-ray diffraction studies of the matrix of the Osceola Mudflow also indicate the presence of finegrained pyrophyllite and quartz. Alteration types 1 and 2 are common in the Osceola Mudflow and have been recognized in exposures of the mudflow along the White River near Greenwater (fig. 51). Alteration type 3 has not been found in the Osceola Mudflow.

Assemblage 1 alteration (smectite-pyrite) is present in large numbers of clasts in the Osceola Mudflow and in other Holocene debris flows from Mount Rainier (fig. 52). Clay minerals replace mafic phenocrysts and groundmass and fill vesicles (fig. 53 and 54). Plagioclase phenocrysts commonly are fresh or only weakly altered, mostly along microfractures. Preliminary $x$-ray diffraction and SEM-EDA studies suggest a range of smectite compositions. Pyrite is present as disseminated crystals, lining vesicles, and filling narrow veins and microfractures. Pyrite abundance commonly reaches 5 to 10 volume percent. Barite inclusions in vein-filling pyrite crystals are present locally.

Assemblage 2 alteration (kaolinite-opal-pyrite \pm alunite \pm pyrophyllite) is less abundant than assemblage 1 in debris flows, probably because this alteration results in softer and more readily abraded rocks. It has been found in clasts in the Osceola Mudflow as far as $50 \mathrm{~km}$ down valley from Mount Rainier. This alteration is much more intense and pervasive than assemblage 1, resulting in complete replacement of igneous minerals and groundmass (figs. 55 and 56). Some clasts of this alteration in the Osceola Mudflow are hydrothermal(?) breccias that are cemented by opal, alunite, kaolinite, and pyrite. Alunite mostly forms fine-grained $(<5 \mu \mathrm{m})$ lath-like crystals locally intergrown with kaolinite (fig. 57). Coarsergrained alunite (as much as $30 \mu \mathrm{m}$ long) locally fills vugs (fig. 58). Pyrite and (or) marcasite content locally reaches 20 percent. Vug-filling anhydrite/gypsum, native sulfur, cinnabar, barite, and fluorite are present locally (fig. 59).

Most alunite crystals from Mount Rainier are Na-rich with molar $\mathrm{K} /(\mathrm{K}+\mathrm{Na}) \approx 0.00$ to 0.30 . Compositional zoning is evident in some well-formed crystals with cores generally having more $\mathrm{K}$-rich compositions than most of the outer parts of the crystals; some crystals also have very narrow $(<1 \mu \mathrm{m}) \mathrm{K}$-rich rims. Some alunites contain $\mathrm{P}$-rich domains with as much as several weight percent $\mathrm{P}_{2} \mathrm{O}_{5}$ (fig. 58). We have not detected phosphate minerals, 
such as woodhouseite $\left(\mathrm{CaAl}_{3}\left(\mathrm{PO}_{4}\right) \mathrm{SO}_{4}(\mathrm{OH})_{6}\right)$ or crandallite $\left(\mathrm{CaAl}_{3}\left(\mathrm{PO}_{4}\right)_{2}(\mathrm{OH})_{5} \cdot \mathrm{H}_{2} \mathrm{O}\right)$, in our samples, although Zimbelman (1996) reported them from outcrops near the summit.

Chemical analyses of 10 samples of altered rocks from the Osceola Mudflow (mostly pyrite-rich smectite alteration) and nine lahar matrix samples indicate strong enrichment of sulfur, but little or no enrichment in most elements characteristic of base- or precious-metal mineral deposits ( $\mathrm{Au}, \mathrm{Ag}$, As, $\mathrm{Sb}, \mathrm{Hg}, \mathrm{Tl}, \mathrm{Cu}, \mathrm{Pb}, \mathrm{Zn}, \mathrm{Bi}$ ). Previous geochemical studies of altered rocks by Zimbelman (1996) and Bruce (1998) showed similar results, although most of their samples were oxidized surface samples.

\section{Stop 4: Osceola Mudflow along White River near Greenwater, Washington}

Many features of the Osceola Mudflow, a clay-rich lahar derived from edifice collapse of Mount Rainier's hydrothermal system 5,600 calendar years B.P. $\left(4,800{ }^{14} \mathrm{C}\right.$ years B.P.), are exposed in outcrops along the right (northeast) bank of the White River near Greenwater. Note that, whereas axialfacies deposits like this one range from a few to $20 \mathrm{~m}$ thick, the Osceola Mudflow filled the valley in this area to the much greater depth of $100 \mathrm{~m}$.

Erosion by the White River has exposed $8 \mathrm{~m}$ of Osceola Mudflow deposit at this location (fig. 51). Underlying the Osceola are runout facies of clay-poor lahars derived from an eruptive episode of Mount Rainier dated between 6,800 and 7,200 calendar years B.P. (6,000 to $6,400{ }^{14} \mathrm{C}$ years B.P.).

The exposure here provides excellent views of the sedimentologic characteristics of a clay-rich lahar deposit. The outcrop is normally graded, not only with respect to the coarse gravel-size fraction, but also with respect to the fraction of sand within the matrix (sand versus sand + silt + clay). Conversely, clay (chiefly of hydrothermal origin in the precollapse edifice) and other particles affected by hydrothermal alteration increase up-section within the outcrop.

Deposits show a progressive downstream improvement in sorting, increase in sand and gravel, and decrease in clay. These downstream progressions are caused by incorporation (bulking) of well-sorted gravel and sand. Normally graded axial deposits, like those in this outcrop show similar trends from top to bottom because of bulking. The coarse-grained basal deposits in valley bottoms are similar to deposits near inundation limits. Normal grading in deposits is best explained by incremental aggradation of a flow wave, coarser grained at its front than at its tail (fig. 60).

A wide variety of hydrothermally altered rocks and hydrothermal minerals from Mount Rainier are present as clasts and matrix in the mudflow here. The larger clasts, as much as $1 \mathrm{~m}$ in wide, are mostly fresh or weakly altered to a smectite-pyrite assemblage. More strongly altered clasts, notably advanced argillic assemblages (kaolinite-pyriteopal \pm alunite), tend to form much smaller, well-rounded clasts. Much of the mudflow matrix here is clay rich. The clay size fraction of the matrix contains smectite, kaolinite, alunite, hydrothermal quartz, and minor pyrophyllite. Unoxidized parts of the clay matrix are dark gray due to the presence of abundant fine-grained pyrite (fig. 50)

\section{Stop 5: Osceola Mudflow in the Corliss Gravel Quarry, Enumclaw, Washington}

The Corliss quarry produces sand from fluvial gravels and glacial kame terraces that banked along the west side of the Cascades Range during late Pleistocene continental glaciation that covered the Puget Sound lowlands. The Osceola Mudflow is exposed locally in the quarry as a 4- to 5-m-thick deposit overlying the fluvial-glacial deposits (fig. 61). In this stop, we will compare characteristics of the Osceola exposed here to the Osceola exposed near Greenwater (stop 4), about $25 \mathrm{~km}$ farther up the White River Valley and closer to the source of the mudflow on Mount Rainier.

The Osceola Mudflow in the Corliss quarry consists mostly of rounded cobbles and small boulders as much as about $50 \mathrm{~cm}$ wide (fig. 62). Quaternary andesites from Mount Rainier are the most common clasts, but clasts of Tertiary andesites, welded tuffs and granites also are common. The ratio of rocks from Quaternary Mount Rainier to older rocks is much lower here than at the Greenwater locality, an indication of "bulking" of the mudflow by incorporation of surface materials that it passes over. Hydrothermally-altered clasts are much less common than at Greenwater, probably indicating both dilution by incorporation of surface materials (bulking) and mechanical abrasion of the softer, hydrothermally-altered rocks during transport. The Osceola here also contains small trees and tree branches that were incorporated during flowage (figs. 61 and 62).

The matrix of the Osceola Mudflow in the Corliss quarry is a gray sand that is noticeably more clay rich than the underlying fluvial and glacial deposits, but much less clay rich than the matrix of the Osceola at the Greenwater stop. A 1 to 2 $\mathrm{cm}$ thick, Fe-rich hardpan is present locally at the base of the Osceola (fig. 63).

\section{References}

Armstrong, J.E., Crandell, D.R., Easterbrook, D.J., and Noble, J.B., 1965, Late Pleistocene stratigraphy and chronology in southwestern British Columbia and northwestern Washington: Geological Society of America Bulletin, v. 76, no. 3, p. 321-330.

Arribas, Antonio, Jr., 1995, Characteristics of high-sulfidation epithermal deposits, and their relation to magmatic fluid, in Thompson, J.F.H., ed., Magmas, fluids, and ore deposits: Mineralogical Association of Canada Short Course Series, v. 23 , p. $419-454$.

Ashley, R.P., Rytuba, J.J., John, D.A., Blakely, R.J., Box, S.E., and Newport, G., 2003, The White River silica deposits, Washington: Upper parts of an early Miocene porphyry $\mathrm{Cu}-$ Au system? [abs.]: Geological Society of America Abstracts with Programs, v. 35, n. 6, p. 232-233. 
Blakely, R.J., 1995, Potential theory in gravity and magnetic applications: New York, Cambridge University Press, 441 p.

Blakely, R.J., and Simpson, R.W., 1986, Approximating edges of source bodies from magnetic or gravity anomalies: Geophysics, v. 51, p. 1494-1498.

Blakely, R.J., Wells, R.E., and Weaver, C.S., 1999, Puget Sound aeromagnetic maps and data: U.S. Geological Survey Open-File Report 99-514, http://geopubs.wr.usgs.gov/openfile/of99-514.

Breit, G.N., Rye, R.O., John, D.A., Kester, C.L., and Berry, C.J., 2003, Isotopic studies of sulfur-bearing minerals in the clasts and matrix of Holocene debris flows from Mount Rainier, Washington [abs.]: Geological Society of America Abstracts with Programs, v. 35, n. 6, p. 553.

Bruce, V.L., 1998, Geochemistry of hydrothermal alteration along a radial transect from the summit of Mount Rainier, Washington: Riverside, University of California, M.S. thesis, $120 \mathrm{p}$.

Callaghan, Eugene, 1940, Alunite deposits near Enumclaw, King and Pierce Counties, Washington: unpub. U.S. Geological Survey report, 12 p. plus table.

Christiansen, R.L., and Yeats, R.S., 1992, Post-Laramide geology of the U.S. Cordilleran region, in Burchfiel, B.C., Lipman, P.W., and Zoback, M.L., eds., The Cordilleran Orogen; Conterminous U.S.: Boulder, CO, Geological Society of America, the Geology of North America, v. G-3, p. 261-406.

Crandell, D.R., 1963, Surficial geology and geomorphology of the Lake Tapps quadrangle, Washington: U.S. Geological Survey Professional Paper 388-A, 84 p.

Crandell, D.R., 1971, Postglacial lahars from Mount Rainier National Park, Washington: U.S. Geological Survey Professional Paper 677, 75 p.

Dragovich, J., Pringle, P.T., and Walsh, T.J., 1994, Extent and geometry of the mid-Holocene Osceola Mudflow in the Puget Sound Lowland-Implications for Holocene sedimentation and paleogeography: Washington Geology, v. 22, no. 3, p. 3-26.

Glover, S.L., 1936, Nonmetallic mineral resources of Washington: Washington Division of Geology Bulletin 33, 135 p.

Gustafson, L.B., and Hunt, J.P., 1975, The porphyry copper deposit at El Salvador, Chile: Economic Geology, v. 70, p. 857-912.

Heald, P., Foley, N.K., and Hayba, D.O., 1987, Comparative anatomy of volcanic-hosted epithermal deposits: Acid sulfate and adularia-sericite types: Economic Geology, v. 82, p. 1-26.

Hedenquist, J.W., 1990, The thermal and geochemical signature structure of the Broadlands-Ohaaki geothermal system: Geothermics, v. 19, p. 151-185.
Hedenquist, J.W., Arribas, Antonio, Jr., and Gonzalez-Urien, Eliseo, 2000, Exploration for epithermal gold deposits, in Hagemann, S.G., and Brown, P.E., eds., Gold in 2000: Reviews in Economic Geology, v. 13, p. 245-277.

Huntting, M.T., 1955, Gold in Washington: Washington Division of Mines and Geology, Bulletin 42, 158 p.

John, D.A., Breit, G.N., Rye, R.O., Sisson, T.W., and Vallance, J.W., 2003, Hypogene hydrothermal alteration of Quaternary volcanic rocks from Mount Rainier, Washington [abs.]: Geological Society of America Abstracts with Programs, v. 35 , n. 6, p. 553.

Kelly, H.J., Strandberg, K.G., and Mueller, J.I., 1956, Ceramic industry development and raw-material resources of Oregon, Washington, Idaho, and Montana: U.S. Bureau of Mines Information Circular 7752, 77 p.

Livingston, V.E., Jr., 1971, Geology and mineral resources of King County, Washington: Washington State Division of Mines and Geology Bulletin, n. 63, 200 p.

Mattinson, J.M., 1977, Emplacement history of the Tatoosh volcanic-plutonic complex, Washington; ages of zircons: Geological Society of America Bulletin, v. 88, p. 15091514.

McCulla, M.S., 1986, Geology and metallization of the White River area, King and Pierce Counties, Washington: Corvallis, Oregon State University, Ph.D. dissertation, 213 p.

Mullineaux, D. R., 1974, Pumice and other pyroclastic deposits in Mount Rainier National Park, Washington: U.S. Geological Survey Bulletin 1326, 83 p.

Plumlee, G.S., Rye, R.O., Breit, G.N., and John, D.A., 2003, Chemical modeling of volcanic gas interactions with ground water and andesite: Insights into hydrothermal alteration at Mount Rainier, Washington [abs.]: Geological Society of America Abstracts with Programs, v. 35, n. 6., p. 553 .

Ransome, F.L., 1909, The geology and ore deposits of Goldfield, Nevada: U.S. Geological Survey Professional Paper 66, $258 \mathrm{p}$.

Rye, R.O., Bethke, P.M., and Wasserman, M.D., 1992, The stable isotope geochemistry of acid-sulfate alteration: Economic Geology, v. 87, p. 225-262.

Rytuba, J.J., John, D.A., Foster, Andrea,, Ludington, S.D., and Kotylar, Boris, in press, Hydrothermal enrichment of gallium in zones of advanced argillic alteration; examples from the Paradise Peak and McDermitt ore deposits, Nevada, in Bliss, J.D., Moyle, P.R., and Long, K.R., eds., Contributions to Industrial-Minerals Research: U.S. Geological Survey Bulletin 2209, Chapter C, 34 p.

Schoen, R., White, D.E., and Hemley, J.J., 1974, Argillization by descending acid at Steamboat Springs, Nevada: Clays and Clay Minerals, v. 22, p. 1-22. 
Sillitoe, R.H., 1999, Styles of high-sulphidation gold, silver, and copper mineralization in the porphyry and epithermal environments: PacRim '99, Bali, Indonesia, 10-13 October, Proceedings, p. 29-44.

Sillitoe, R.H., 2000, Gold-rich porphyry deposits: Descriptive and genetic models and their role in exploration and discovery, in Hagemann, S.G., and Brown, P.E., eds., Gold in 2000: Reviews in Economic Geology, v. 13, p. 315-345.

Sisson, T.W., Lanphere, M.A., and Calvert, A.T., 2003, Alteration and the magmatic history of Mt. Rainier, Washington [abs.]: Geological Society of America Abstracts with Programs, v. 35 , n. 6, p. 552.

Sisson, T.W., Vallance, J.W., and Pringle, P.P., 2001, Progress made in understanding Mount Rainier's hazards: Eos (Transactions, American Geophysical Union), v. 82, p.113120.

Steven, T.A., and Ratte, J.C., 1960, Geology of ore deposits of the Summitville district, San Juan Mountains, Colorado: U.S. Geological Survey Professional Paper 343, 70 p.

Stoffregen, R.E., 1987, Genesis of acid-sulfate alteration and $\mathrm{Au}-\mathrm{Cu}-\mathrm{Ag}$ mineralization at Summitville, Colorado: Economic Geology, v. 82, p. 1575-1591.

Tabor, R.W., Frizzell, V.A., Jr., Booth, D.B., and Waitt, R.B., 2000, Geologic map of the Snoqualmie Pass 30 x 60 minute quadrangle, Washington: U.S. Geological Survey Geologic Investigations Series Map I-2538, scale 1:100,000.
Valentine, G. M., 1960, Inventory of Washington minerals-Part I, Nonmetallic minerals, 2nd ed., revised by M.T. Huntting: Washington Division of Mines and Geology Bulletin 37, v. $1,175 \mathrm{p}$.

Vallance, J.W., and Scott, K.M., 1997, The Osceola Mudflow from Mount Rainier: Sedimentology and hazard implications of a huge clay-rich debris flow: Geological Society of America Bulletin, v. 109, p. 143-163.

Vallance, J.W., Breit, G.N., and John, D.A., 2003, Involvement of a hydrothermal system in the catastrophic 5600 BP eruption of Mount Rainier [abs.]: Geological Society of America Abstracts with Programs, v. 35, n. 6, p. 552-553.

Weyerhaeuser Company, 1996, Summary Report, Weyerhaeuser Exploration Package, White River Properties, King County, Washington, unpublished internal report, $50 \mathrm{p}$.

Zimbelman, D.R., 1996, Hydrothermal alteration and its influence on volcanic hazards-Mount Rainier, Washington, a case history: Boulder, University of Colorado, Ph.D. dissertation, $384 \mathrm{p}$.

Zotov, Alexandre, Mukhamet-Galeev, Alexandre, and Schott, Jacques, 1998, An experimental study of kaolinite and dickite relative stability at $150-300^{\circ} \mathrm{C}$ and the thermodynamic properties of dickite: American Mineralogist, v. 83, p. $515-524$. 


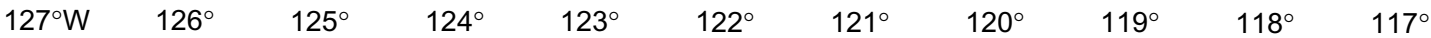

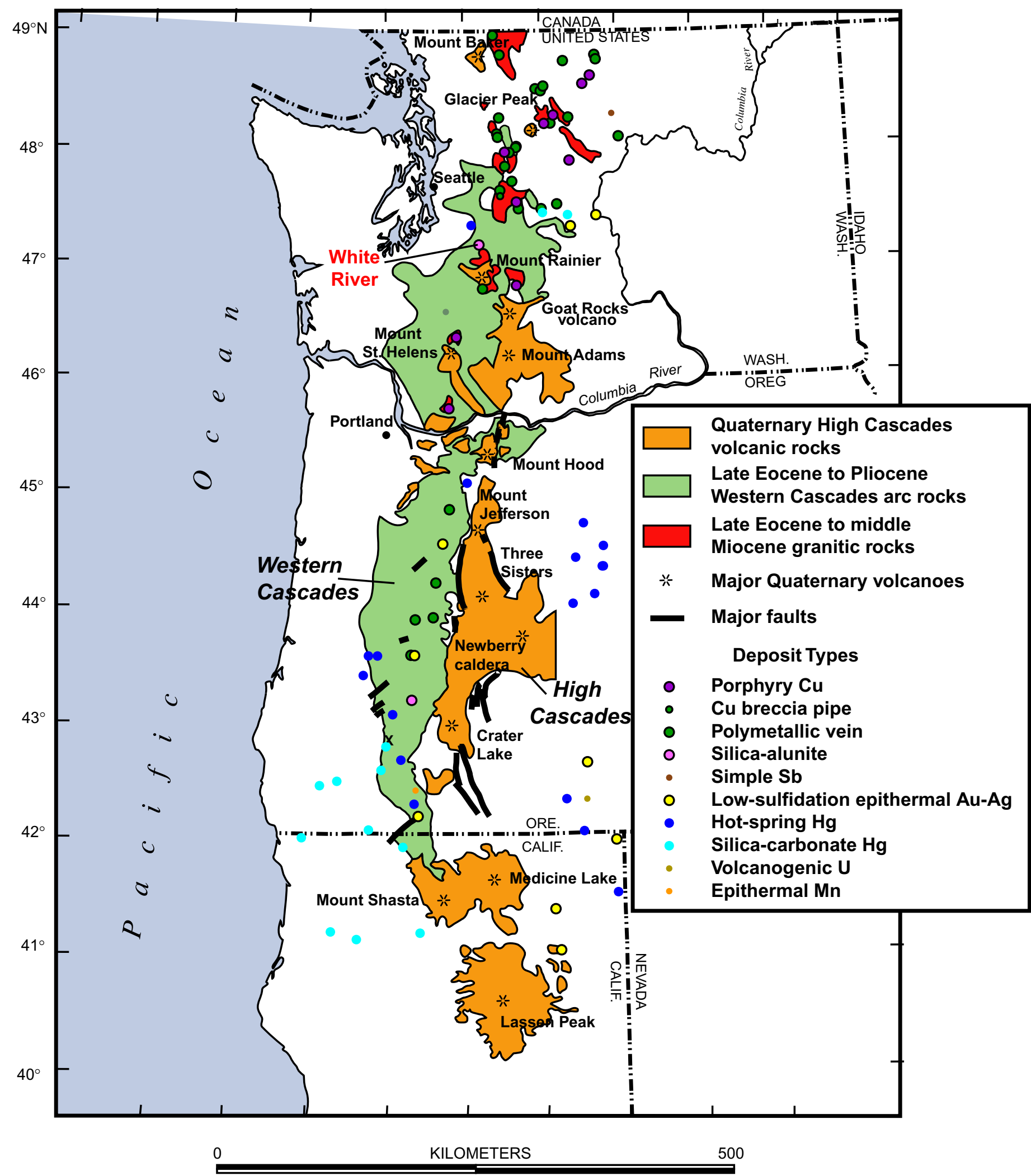

Figure 1. Map showing location of the Western Cascades and High Cascades arcs and mineral deposits in the northwestern United States. Also shown is location of the White River altered area. Mineral deposits from U.S. Geological Survey Mineral Resources Data System database. 


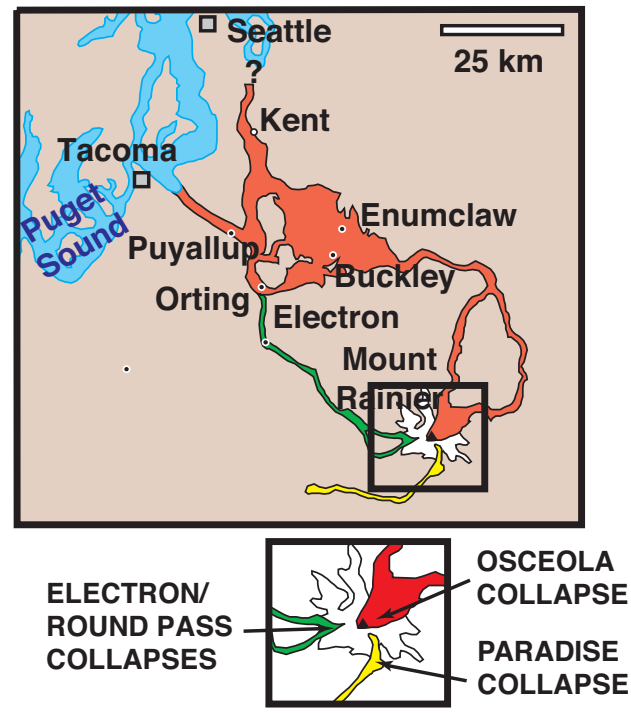

Figure 2. Map showing areas inundated by Holocene debris flows from Mount Rainier. The Osceola and Electron Mudflows and the Paradise and Round Pass lahars all have clay-rich matrixes and contain abundant clasts of hydrothermally altered rocks. Modified from Sisson and others (2001).

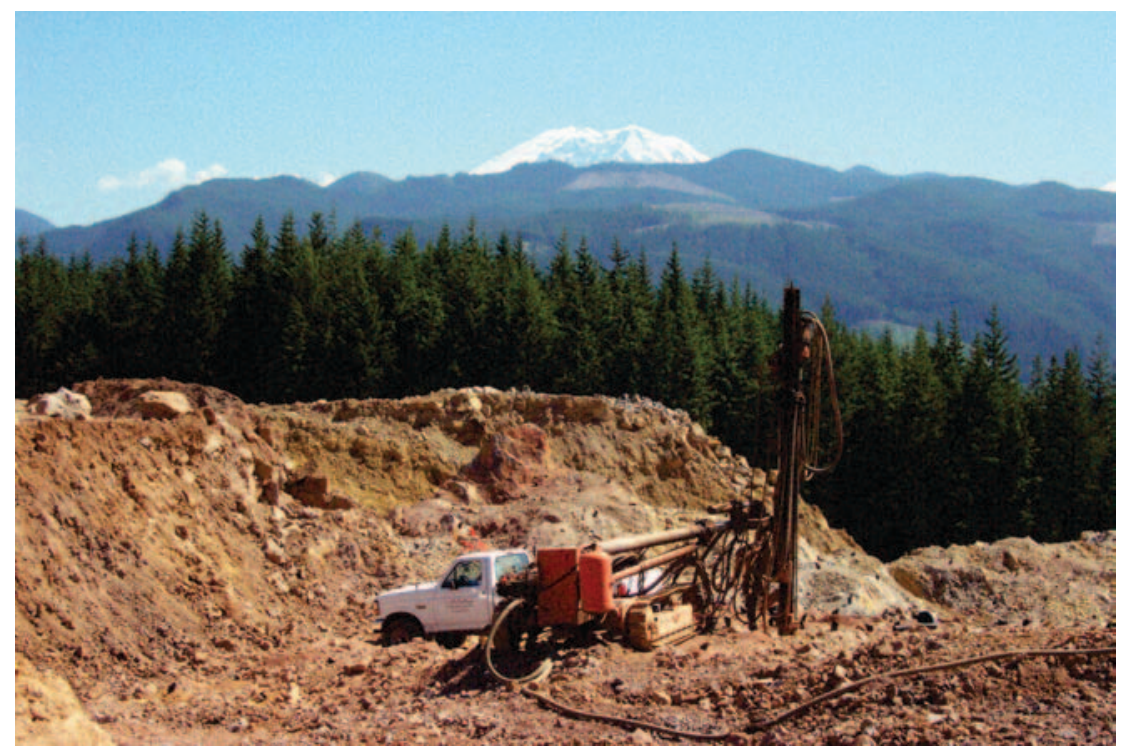

Figure 3. Photograph of vuggy silica alteration in the Scatter Creek (J ames Hardie) silica quarry, White River altered area. Snow-covered Mount Rainier is in the background. 


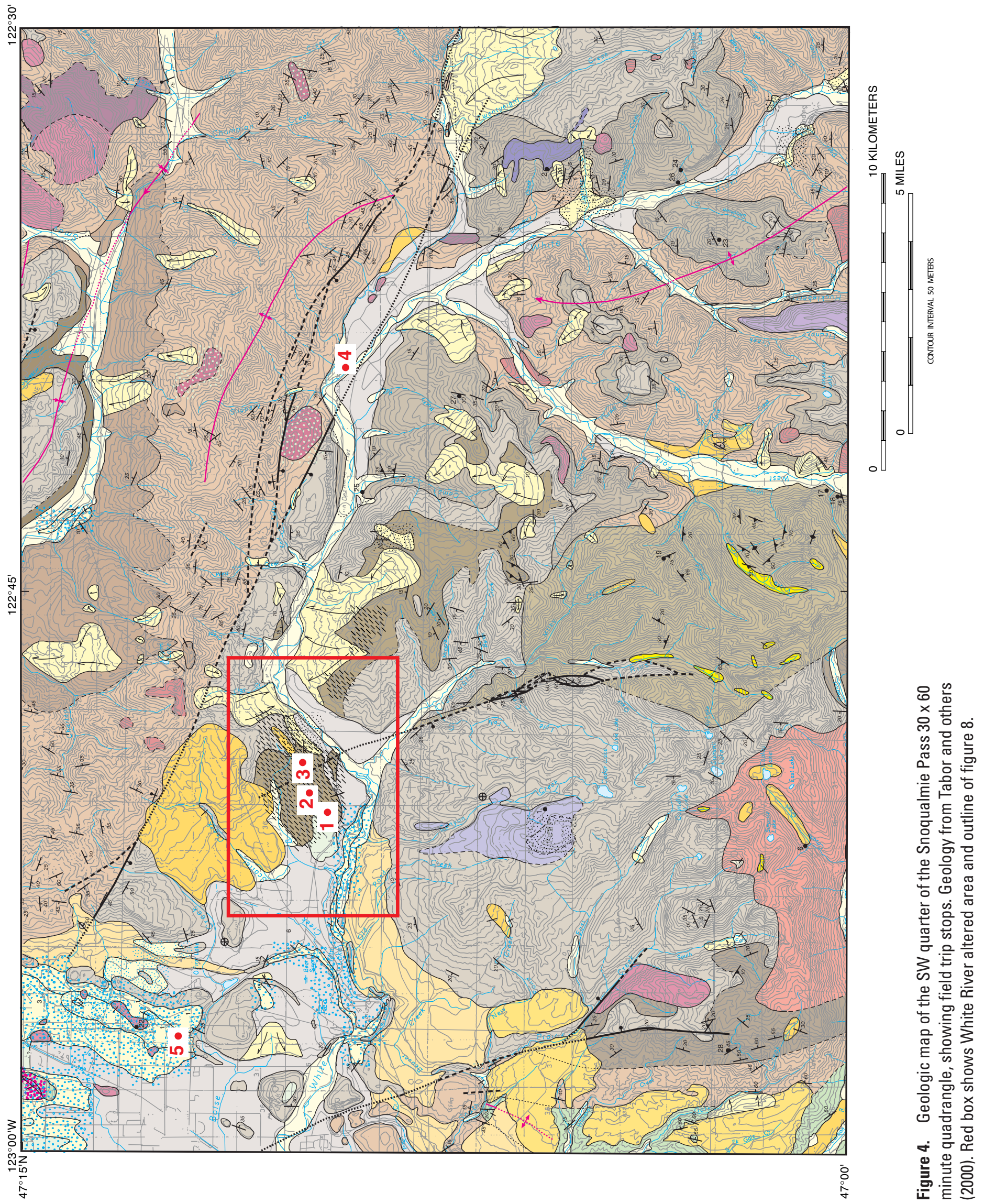


Field Guide to Hydrothermal Alteration in the White River Altered Area and in the Osceola Mudflow, Washington

\section{LIST OF MAP UNITS}

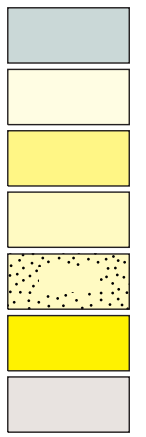

Man-Modified land (Holocene)

Alluvium (Holocene and Pleistocene)

Bog deposits (Holocene and Pleistocene)

Landslide deposits (Holocene and Pleistocene)

Mass-wastage deposits (Holocene and Pleistocene)

Talus deposits (Holocene and Pleistocene)

Lahar deposits (Holocene and Pleistocene)
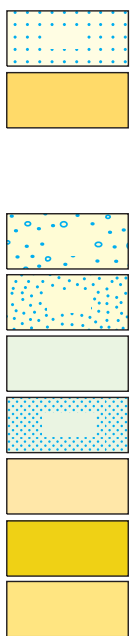

Surficial deposits, undivided (Holocene and Pleistocene)

Alpine glacial deposits (Pleistocene)

Deposits of Vashon stade of Fraser glaciation of Armstrong and others (1965) of Cordilleran ice sheet (Pleistocene)

Recessional outwash deposits

Ice-contact deposits

Till

Advance outwash deposits

Vashon Drift, undivided

Glacial and nonglacial deposits of pre-Fraser glaciation age (Pleistocene)

Alpine glacial drift of pre-Fraser glaciation age (Pleistocene)

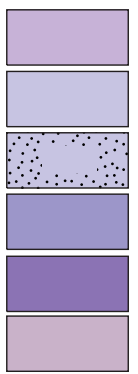

Andesite of Mount Rainier (Pleistocene)

Basalt of Canyon Creek (Pleistocene)

Basaltic tuff and breccia

Basalt of Dalles Ridge (Pliocene)

Howson Andesite (Miocene)

Volcaniclastic rocks of Cooper Pass (Miocene)

Carbon River stock (Miocene)

Intrusive rocks (Miocene and Oligocene)

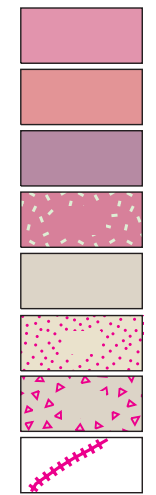

Pyroxene andesite porphyry

Tonalite

Altered porphyry

Dacite porphyry

Fifes Peak Formation (Miocene)

Volcaniclastic rocks

Andesite and basalt megabreccia

Crystal-lithic tuff

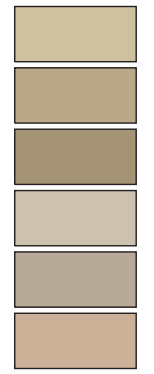

Rhyolite unit of Clear West Peak

Intracaldera rhyolite

Extracaldera rhyolite tuff

Rhyodacite tuff

Sun Top unit

Chenuis Ridge unit

Volcanic rocks of Eagle Gorge (Miocene and Oligocene)

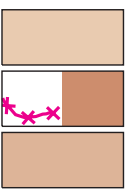

Ohanapecosh Formation (Oligocene)

Tuff member of Lake Keechelus

Volcanic rocks (Oligocene)

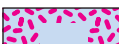

Diabase, gabbro, and basalt (Oligocene? and Eocene)

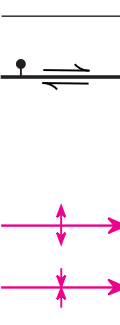

Contact

High-angle Fault

Major Folds

Anticline

Syncline

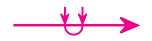

Overturned Syncline

Strike and dip of bedding

$\stackrel{20}{1}$ Inclined

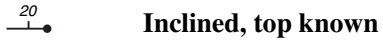

$\stackrel{30}{\jmath^{3}}$ Overturned

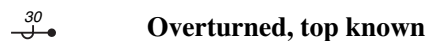

$+\quad$ Vertical

$+\quad$ Vertical, top towards ball

$\oplus \quad$ Horizontal

Strike and dip of foliation

$\stackrel{20}{2}$ Inclined

$\neg \quad$ Vertical

${ }^{40} \quad$ Lineation

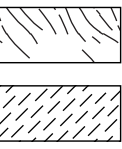

Zone of sheared rock

Zone of silicified rhyolite

Crest of moraine

$\Longleftarrow \quad$ Spillway

$\longleftarrow$ Landslide arrow

5 - Field trip stops

Figure 4. Geologic map of the SW quarter of the Snoqualmie Pass $30 \times 60$ minute quadrangle, showing field trip stops. Geology from Tabor and others (2000). Red box shows White River altered area and outline of figure 8-Continued. 


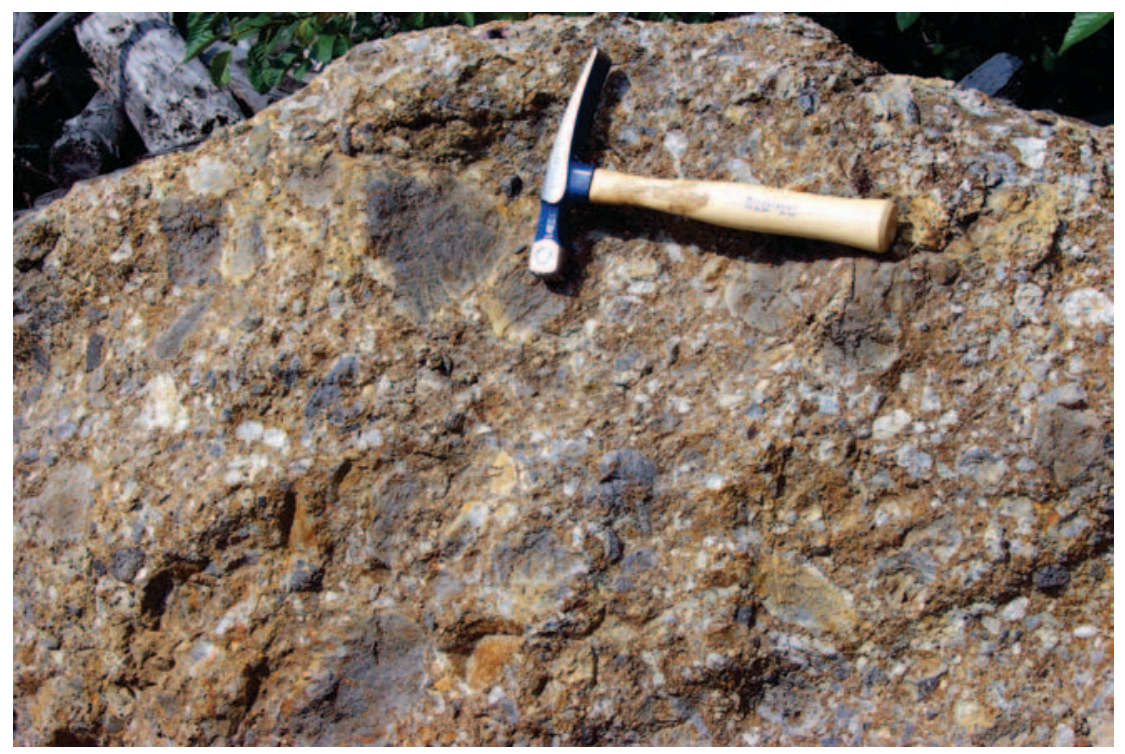

Figure 5. Heterolithic breccia (lahar) in the Fifes Peak Formation. Rock consists of unaltered clasts of several types of andesite in a propylitically or argillically altered matrix.

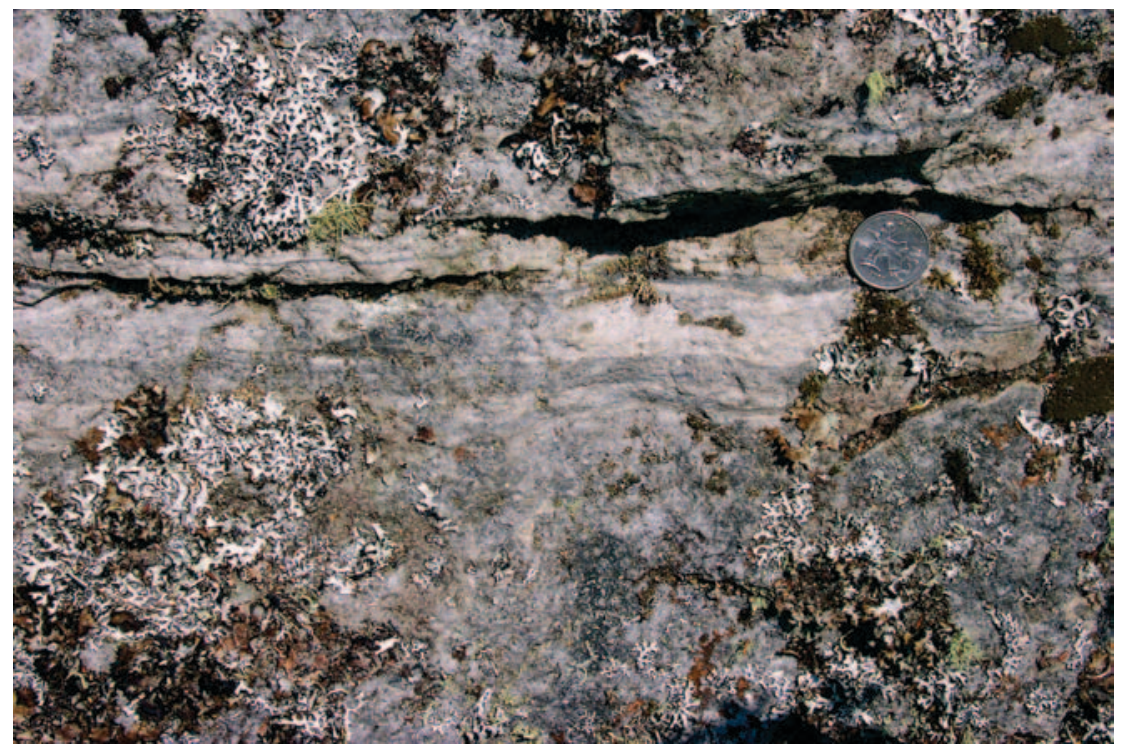

Figure 6. Subhorizontal, finely bedded tuffs from small outcrop about $0.5 \mathrm{~km}$ north of the Superior quarry. Tuff is variably silicified or altered to alunite.

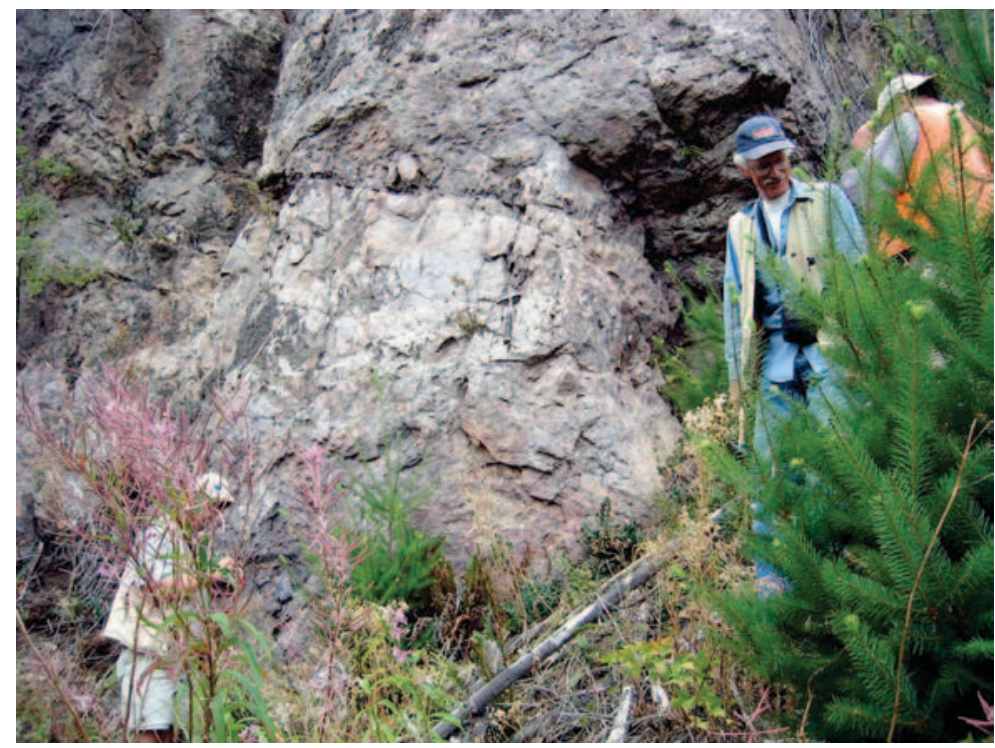

Figure 7. Silicified flow-banded dacite showing large flow fold open to the left side of photo. Cliffs above WA SR 410 south of the Superior quarry. 


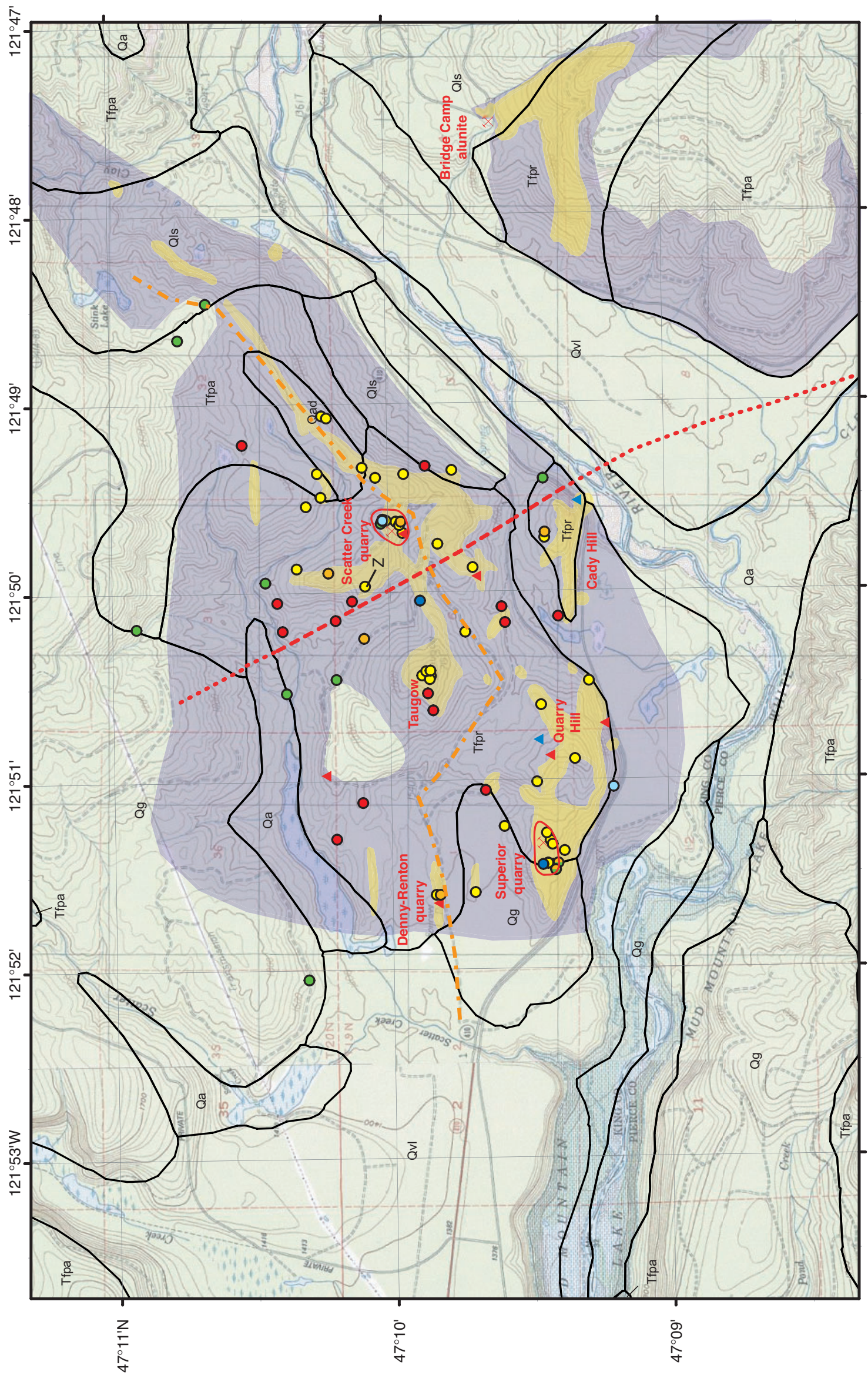

坖京

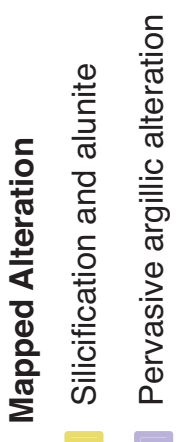

言政

恶

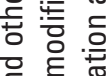

तิ

๘

可 $\frac{\overline{2}}{\sqrt{2}}$

듬 음 뭉

రृ \&

离

此 壱

든은

을

으 \올

은

文审票

항 ह

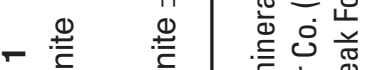

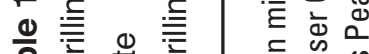

乡

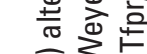

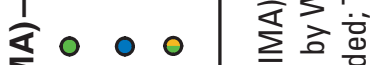

高

웜 产

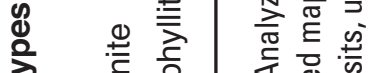

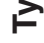

드 올 일

뜬 등 음

峑 044

高 을

잉

ช $\stackrel{0}{ \pm} \stackrel{0}{ \pm}$

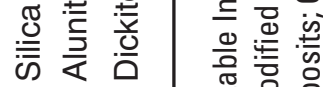

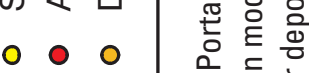

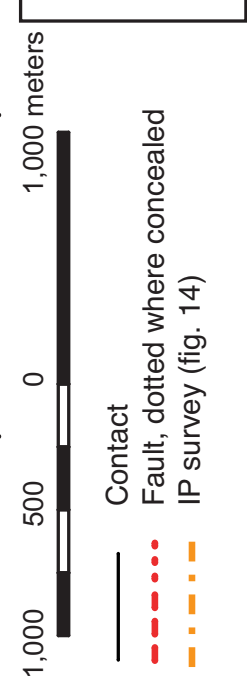

ㄷㅎㅎ 흘 흔

믄 흔

㐫

त्त

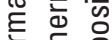

흥 엉

을 을 음

들든 은

पू कृ

드 힌

일

ㅎํㅇ

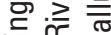

范

के

융ㅇㅇ

.

め 凹

흔 苞 응 
Field Guide to Hydrothermal Alteration in the White River Altered Area and in the Osceola Mudflow, Washington

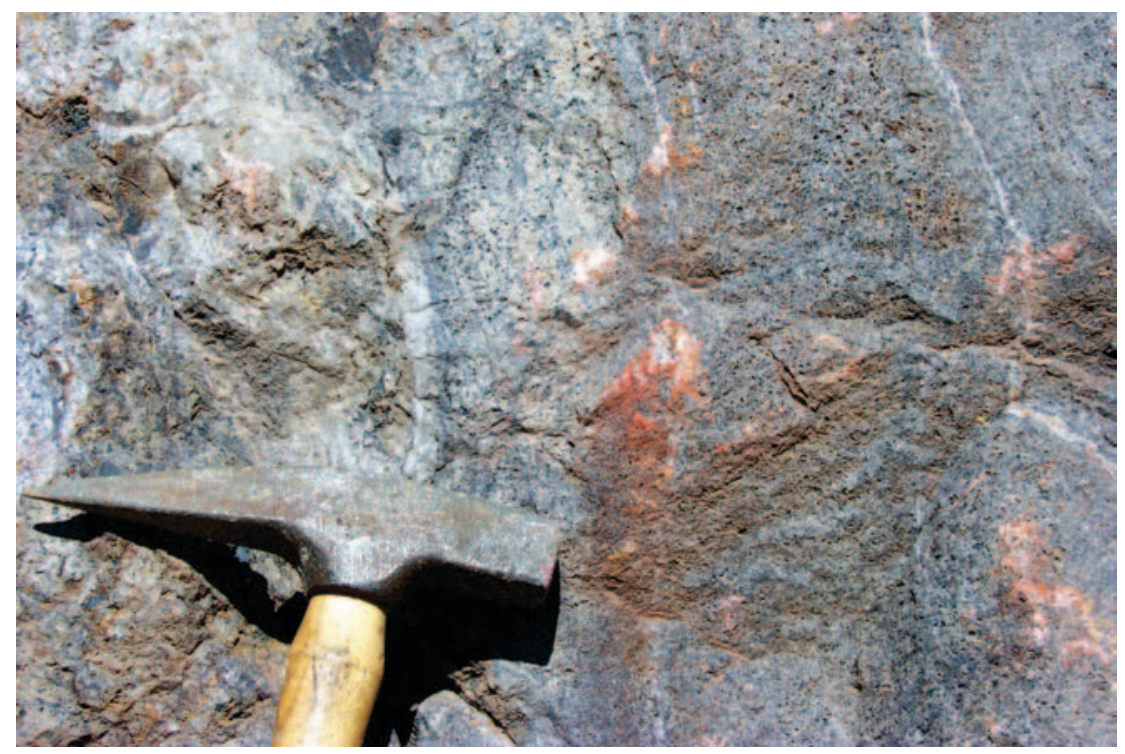

Figure 9. Voids developed from leaching of plagioclase and pyroxene phenocrysts in a porphyritic andesite flow in the Fifes Peak Formation by acidic hydrothermal fluids during vuggy silica alteration. Late, white chalcedonic silica locally replaces and infills the gray vuggy silica. Scatter Creek quarry.

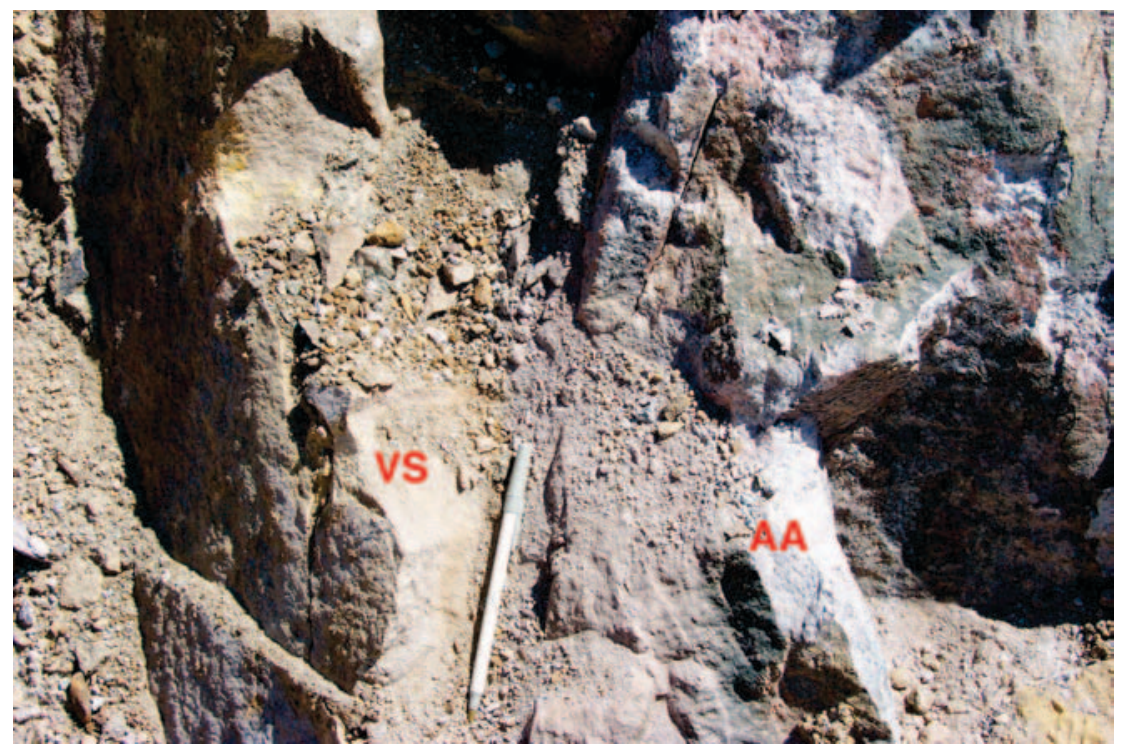

Figure 10. Sharp contact shown by pen between vuggy silica alteration (VS) and alunitic alteration (AA) exposed in narrow northeast-trending rib in the Scatter Creek quarry (also see figs. 38 and 42). 


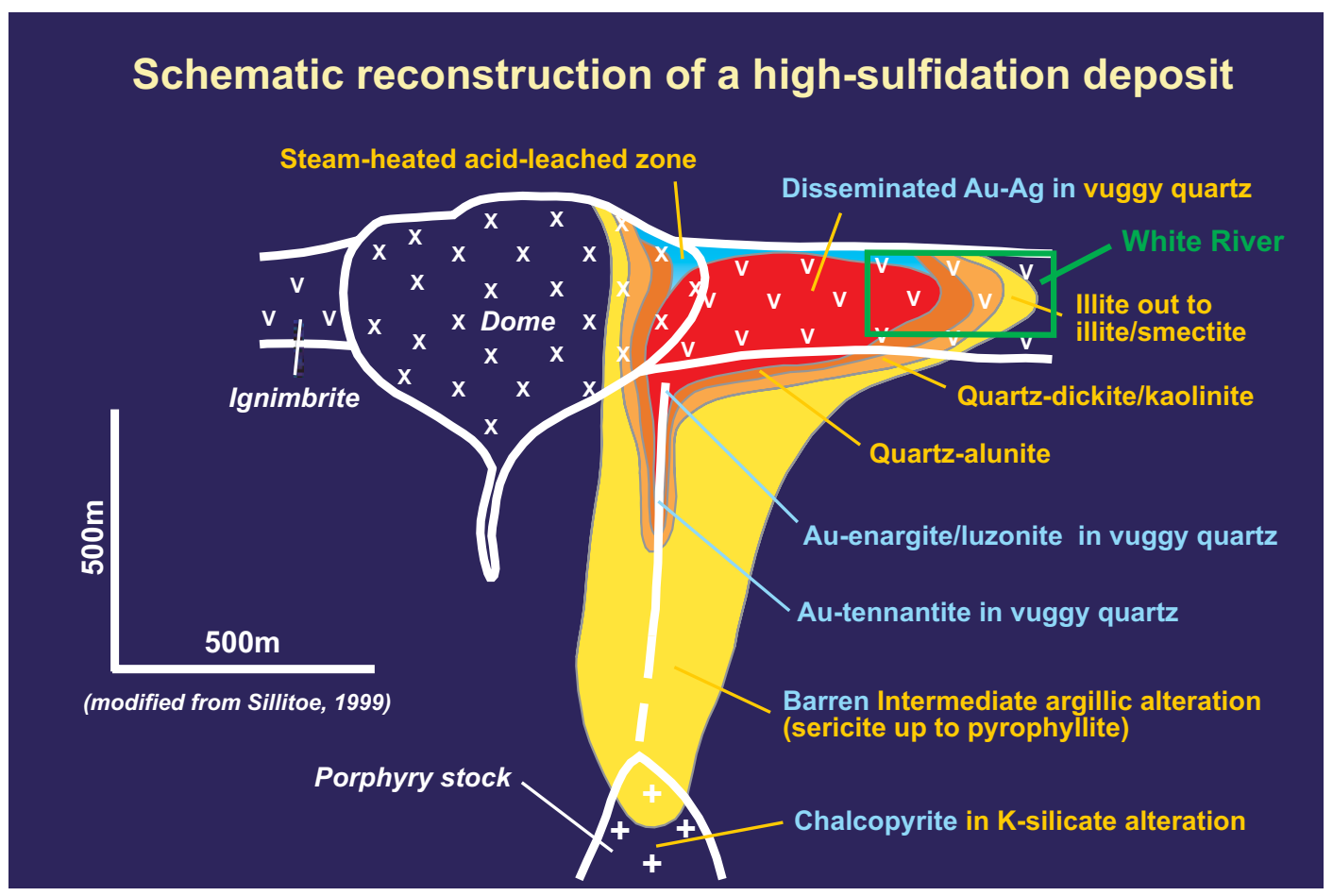

Figure 11. Schematic model for high-sulfidation gold deposits, showing zoning of hydrothermal alteration assemblages and ore types. Most of the White River altered area is inferred to have formed in the uppermost part of this type of hydrothermal system where vuggy silica alteration is extensively developed in permeable horizons (green box). Figure courtesy of Antonio Arribas, Jr., and based on Sillitoe (1999).

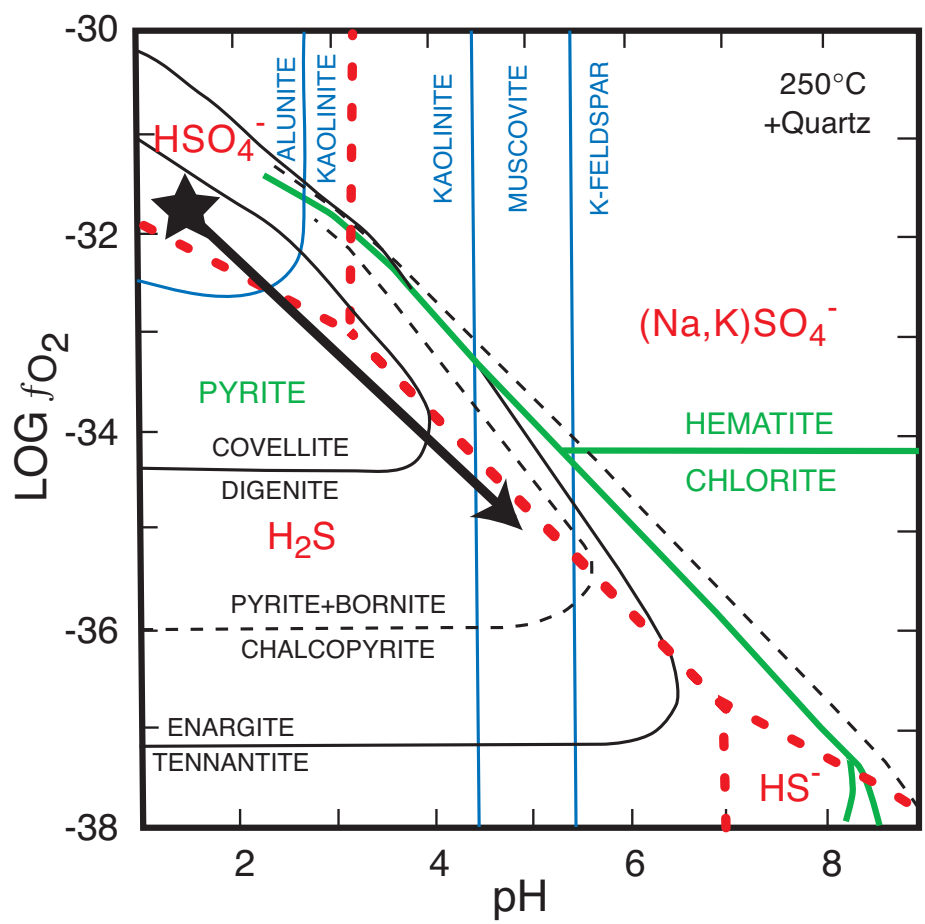

Figure 12. Log $\mathrm{fO}_{2}-\mathrm{pH}$ diagram at $250^{\circ} \mathrm{C}$, total sulfur $=0.02$ molal, salinity=1 molal with $\mathrm{Na} / \mathrm{K}=9$, and quartz saturation, modified from Heald and others (1987). Magmatic-hydrothermal fluids forming vuggy silica alteration (star) likely had $\mathrm{pH}<2$ where Al solubility dramatically increases (Stoffregen, 1987). Progressive reaction of this acidic fluid with relatively reduced, plagioclase feldspar-rich wall rocks increased the $\mathrm{pH}$ and lowered the oxygen fugacity of the fluid resulting in zones of quartz-alunite, quartz-kaolinite, and quartz-muscovite (illite) alteration outward from fluid conduits as indicated by arrow. At higher temperatures $\left(>270^{\circ} \mathrm{C}\right)$, pyrophyllite will replace kaolinite. Stability relations between kaolinite and dickite are uncertain and may reflect higher temperature stability of dickite and/or kinetics (Zotov and others, 1998). 
Field Guide to Hydrothermal Alteration in the White River Altered Area and in the Osceola Mudflow, Washington

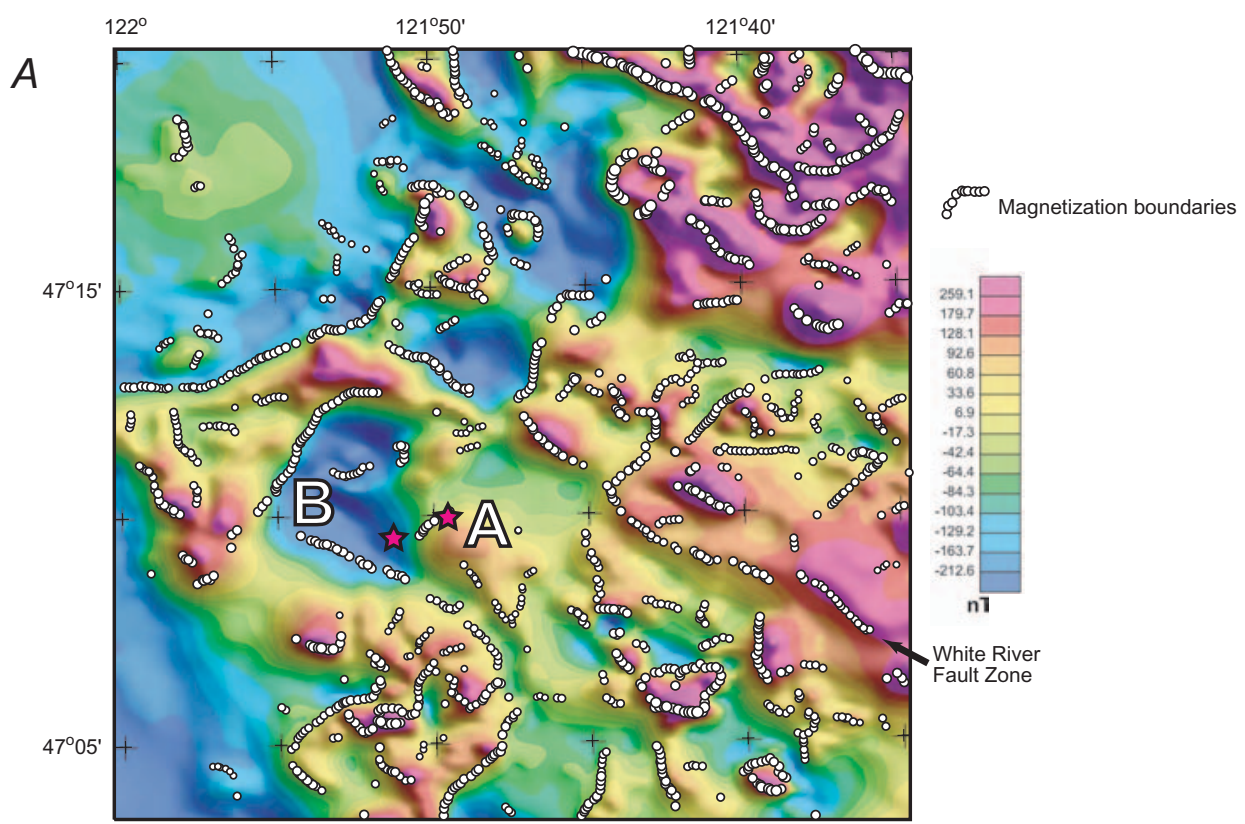

$B$
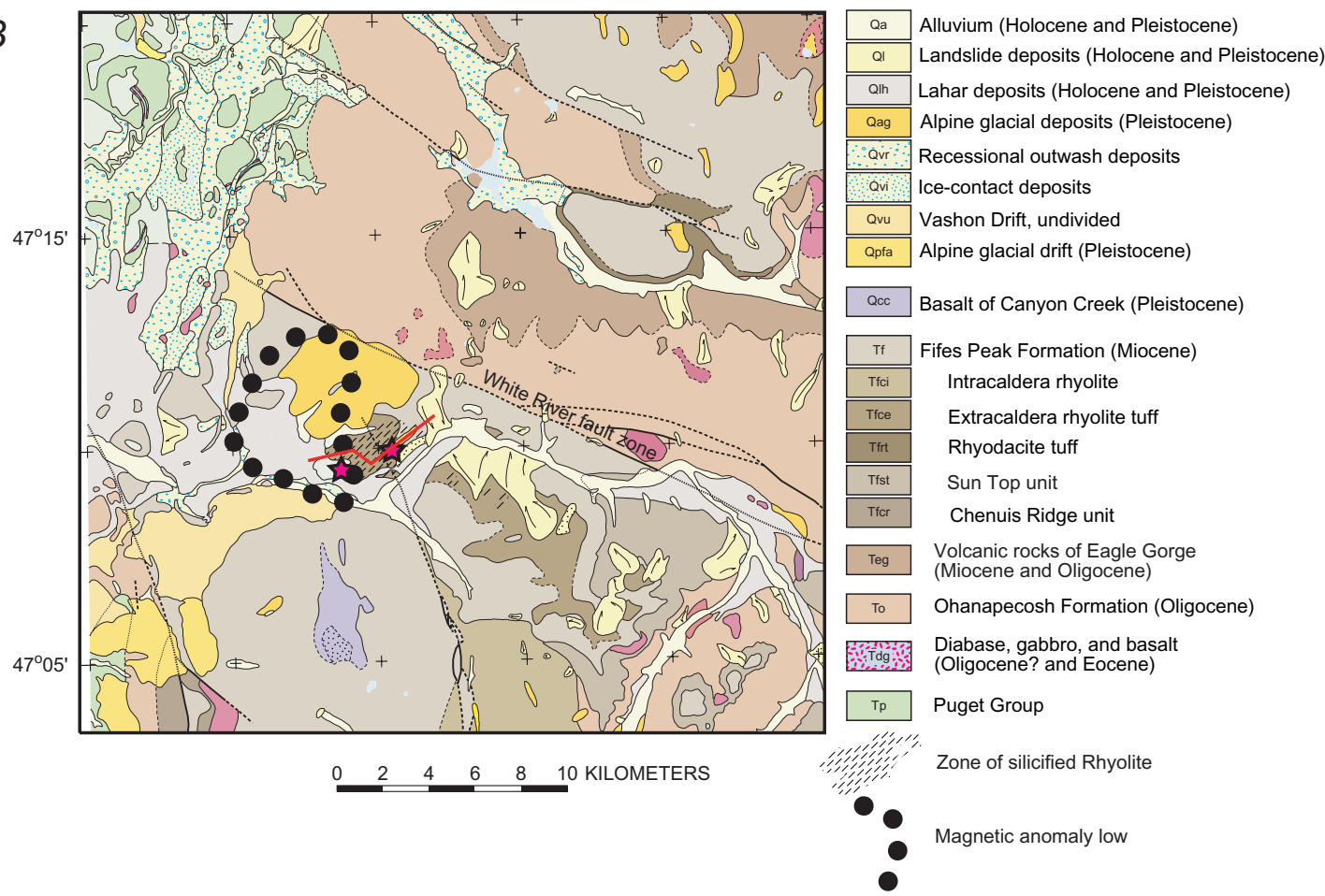

Figure 13. A, Aeromagnetic anomalies of the White River altered area and surrounding regions. White dots represent magnetic contacts calculated automatically using the method of Blakely and Simpson (1986). Magenta stars indicate location of Superior (Ash Grove) and Scatter Creek (James Hardie) quarries. Labels $A$ and $B$ indicate negative and positive anomalies discussed in text. $B$, Geologic map of the White River altered area, modified from Tabor and others (2000). The bold, dotted polygon shows the location of the aeromagnetic low, determined from the magnetic-contact analysis. Red line shows induced polarization (IP) profile shown in figure 14. 
Field Guide to Hydrothermal Alteration in the White River Altered Area and in the Osceola Mudflow, Washington
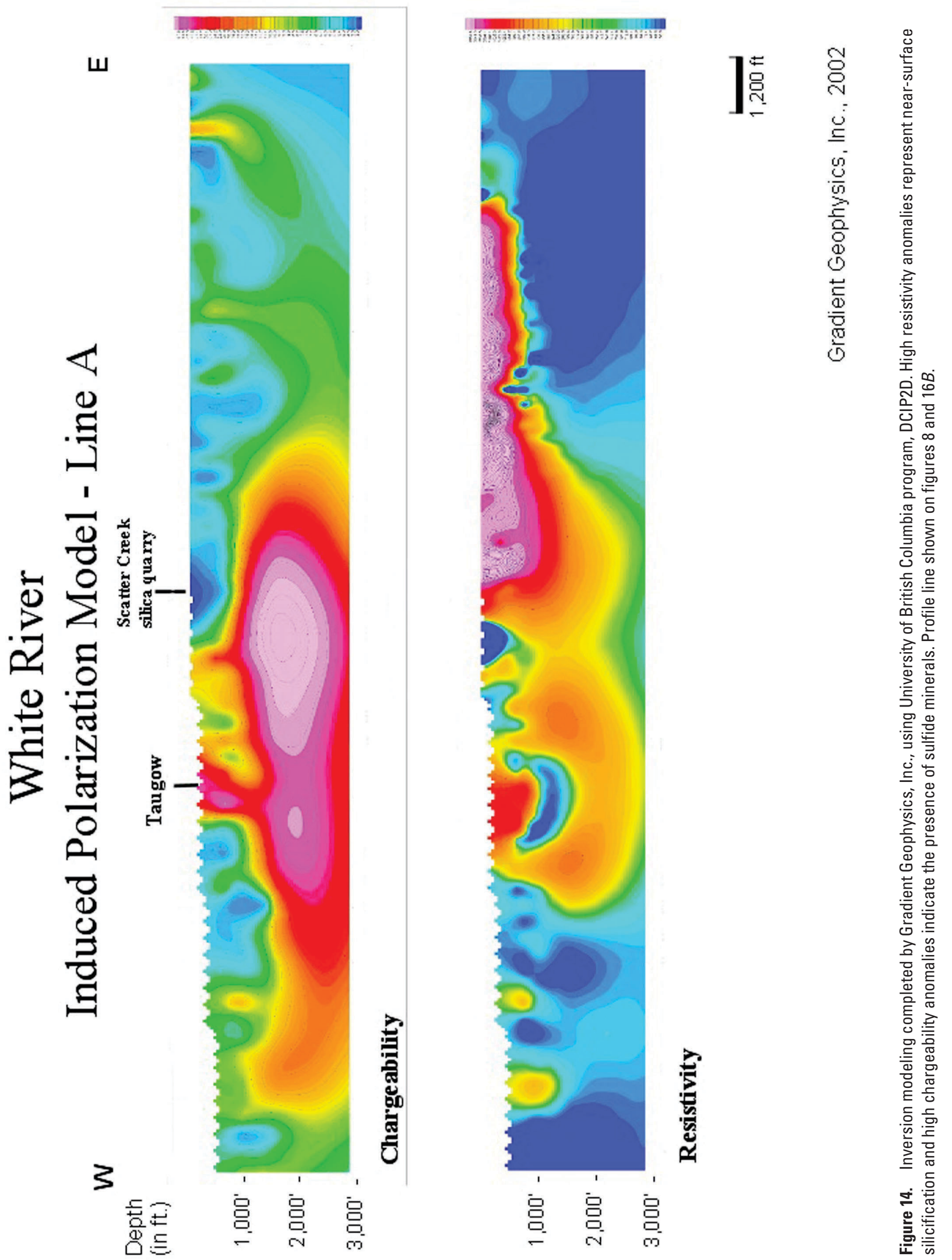
Field Guide to Hydrothermal Alteration in the White River Altered Area and in the Osceola Mudflow, Washington
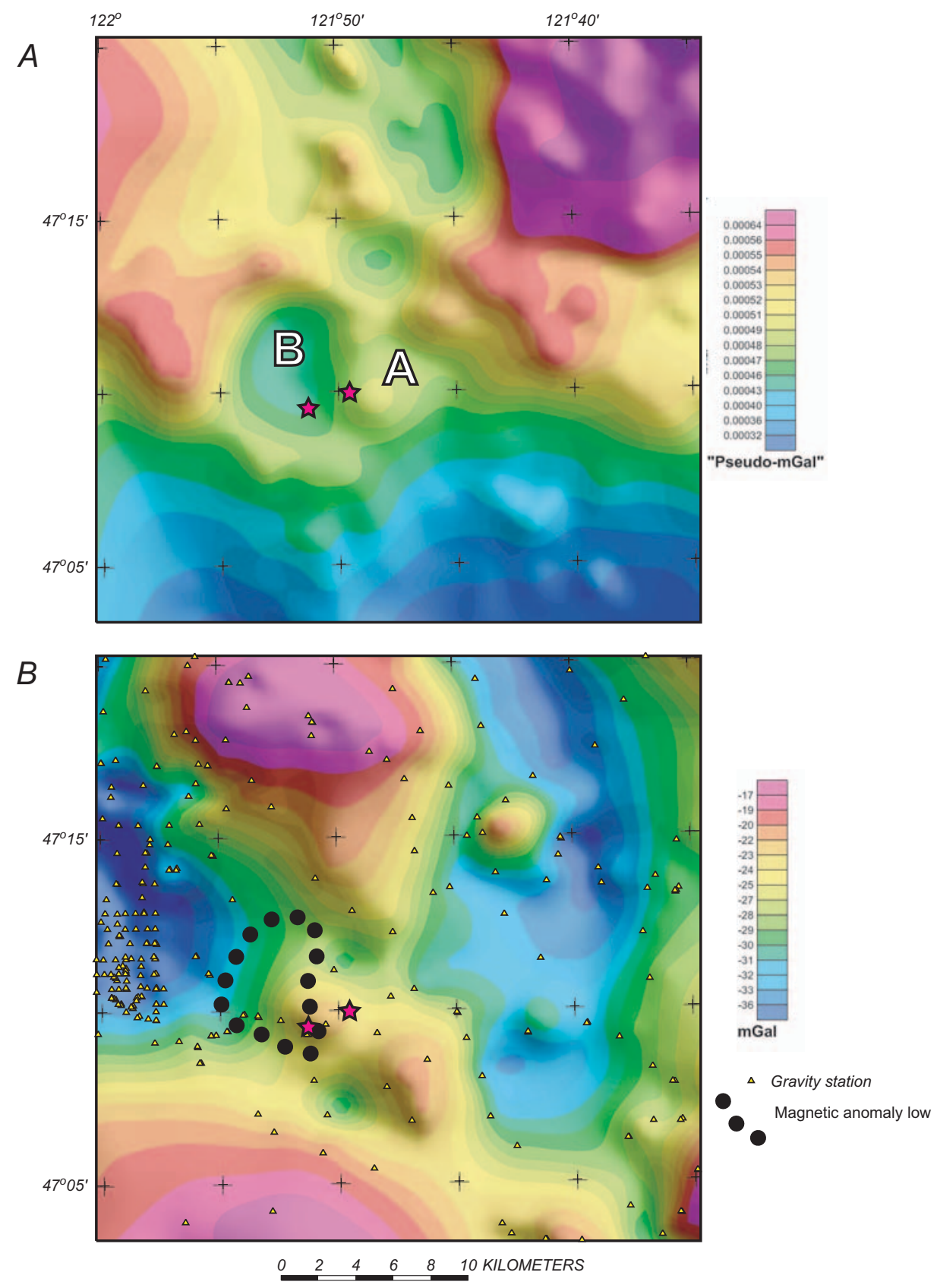

Figure 15. A, Observed aeromagnetic anomalies transformed to pseudogravity. $B$, Observed isostatic residual gravity anomalies. Yellow triangles are gravity stations. See figure 13 for other symbols. 
Field Guide to Hydrothermal Alteration in the White River Altered Area and in the Osceola Mudflow, Washington

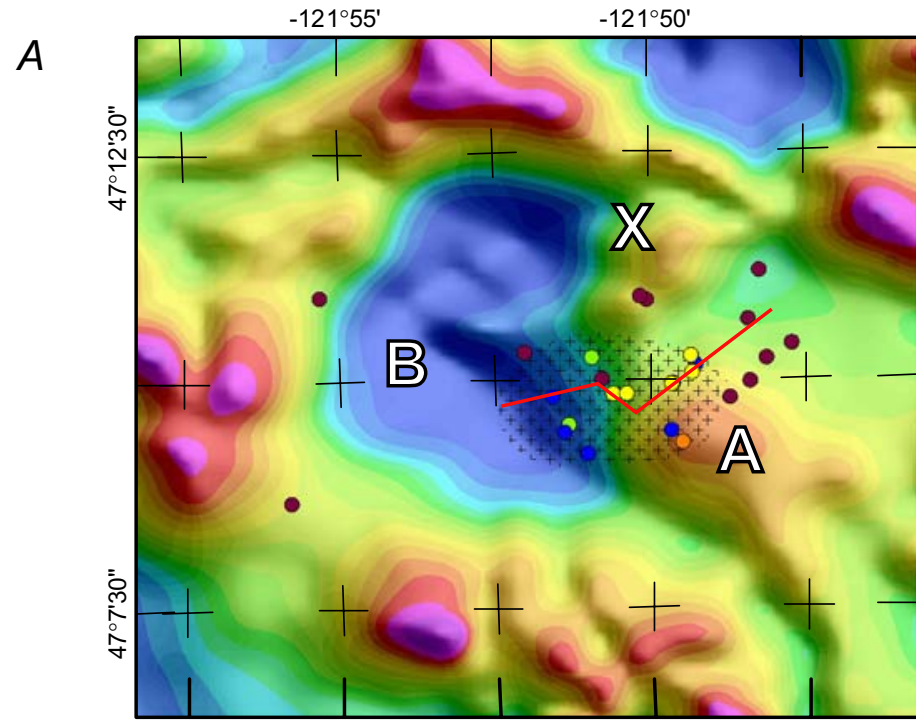

Magnetic Susceptibility (SIU X 1000)

$B$
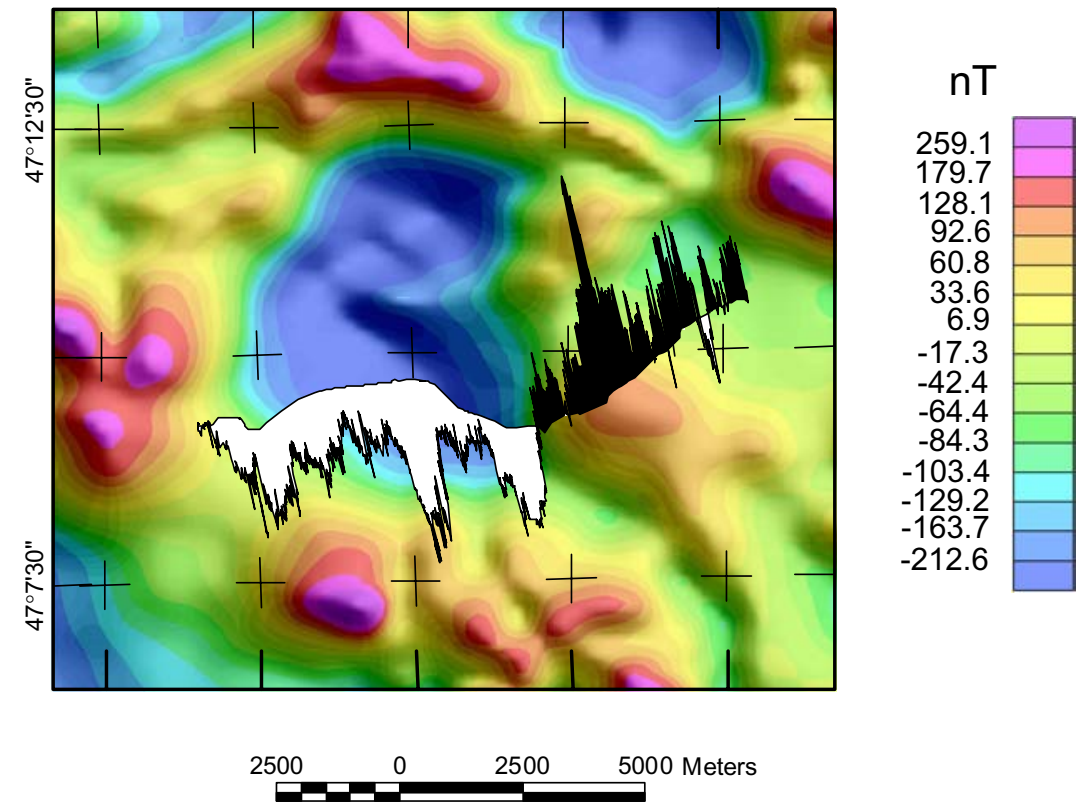

Figure 16. Ground-magnetic studies. A, Map showing the location of all susceptibility measurements (dots) with respect to aeromagnetic anomalies. Susceptibility color coded by value. Stipple pattern, is zone of silicified rhyolite (Tabor and others, 2000). Labels A and B indicate anomalies discussed in text. X indicates susceptibility measurement of laterally restricted area of unaltered basalt. $B$, Representative ground-magnetic profile plotted along route and in map projection. Black and white fill indicates positive and negative anomaly, respectively, relative to base station at Taugow. 


\section{Profile 6-5-4}

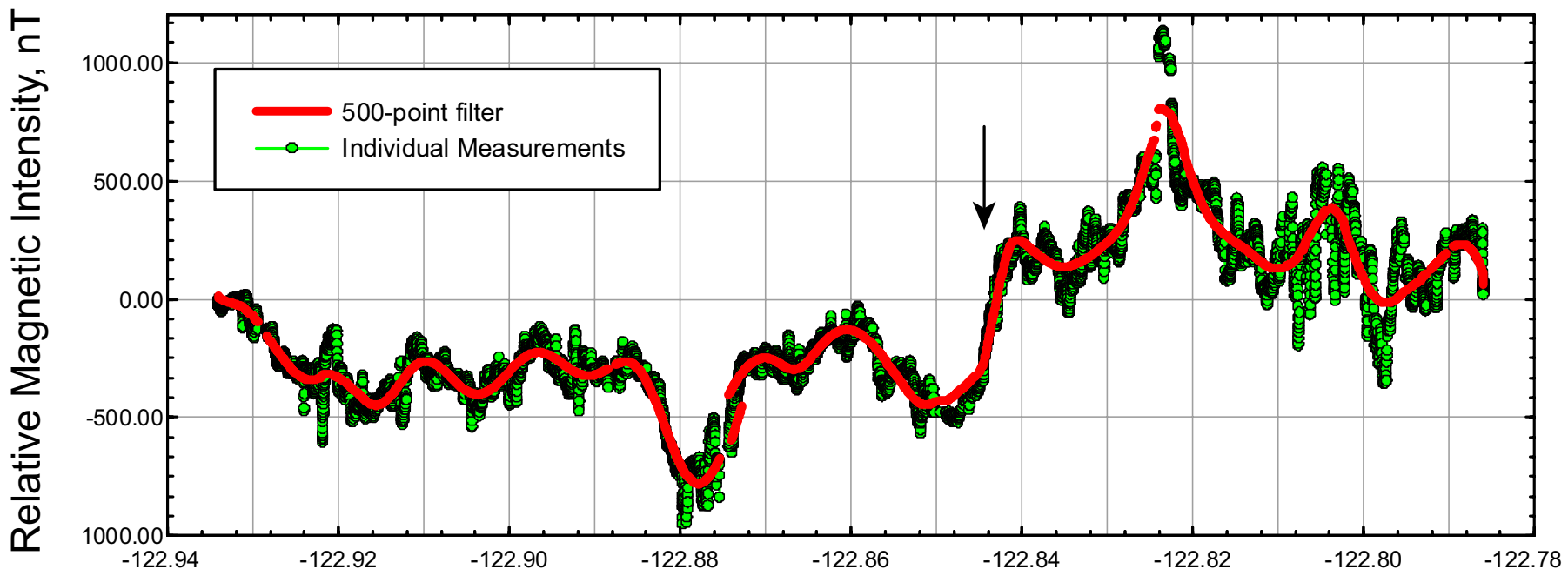

Figure 17. Ground-magnetic profile across White River altered zone. See figure 16 for profile location. Values along profile have been projected onto an east-west line and are shown relative to base-station measurements at Taugow. Green dots are individual measurements; red line is low-pass version of individual measurements. Arrow indicates magnetic gradient discussed in text.

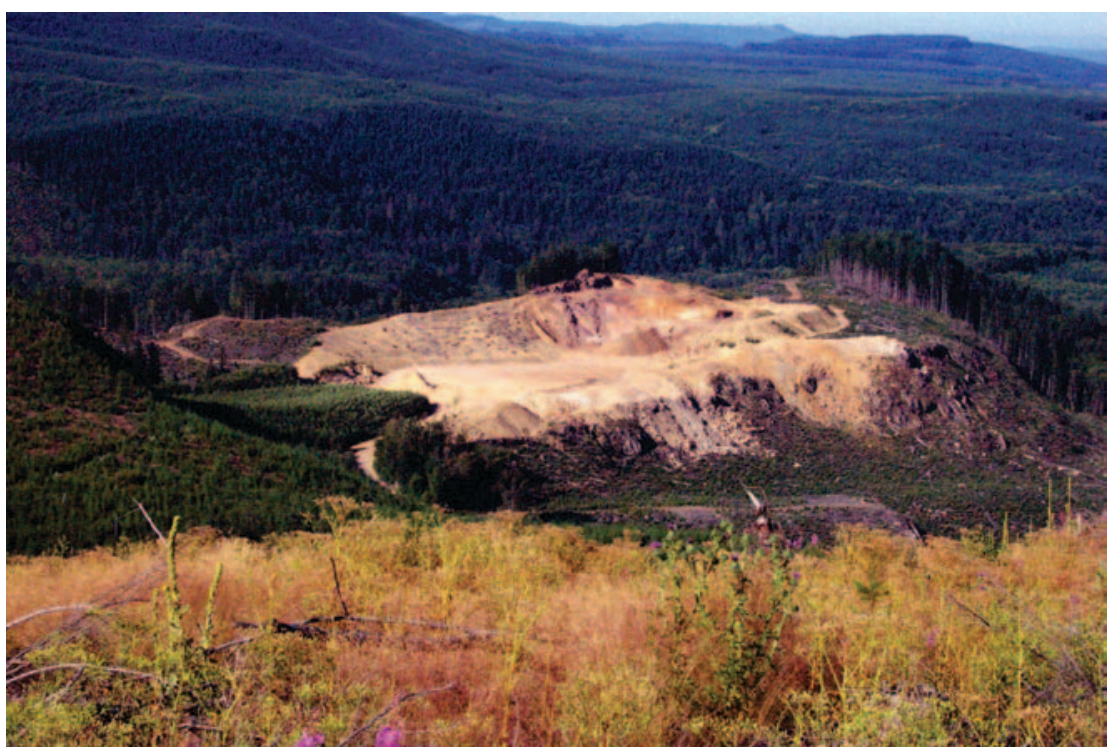

Figure 18. View of the Superior (Ash Grove) quarry from Taugow. 


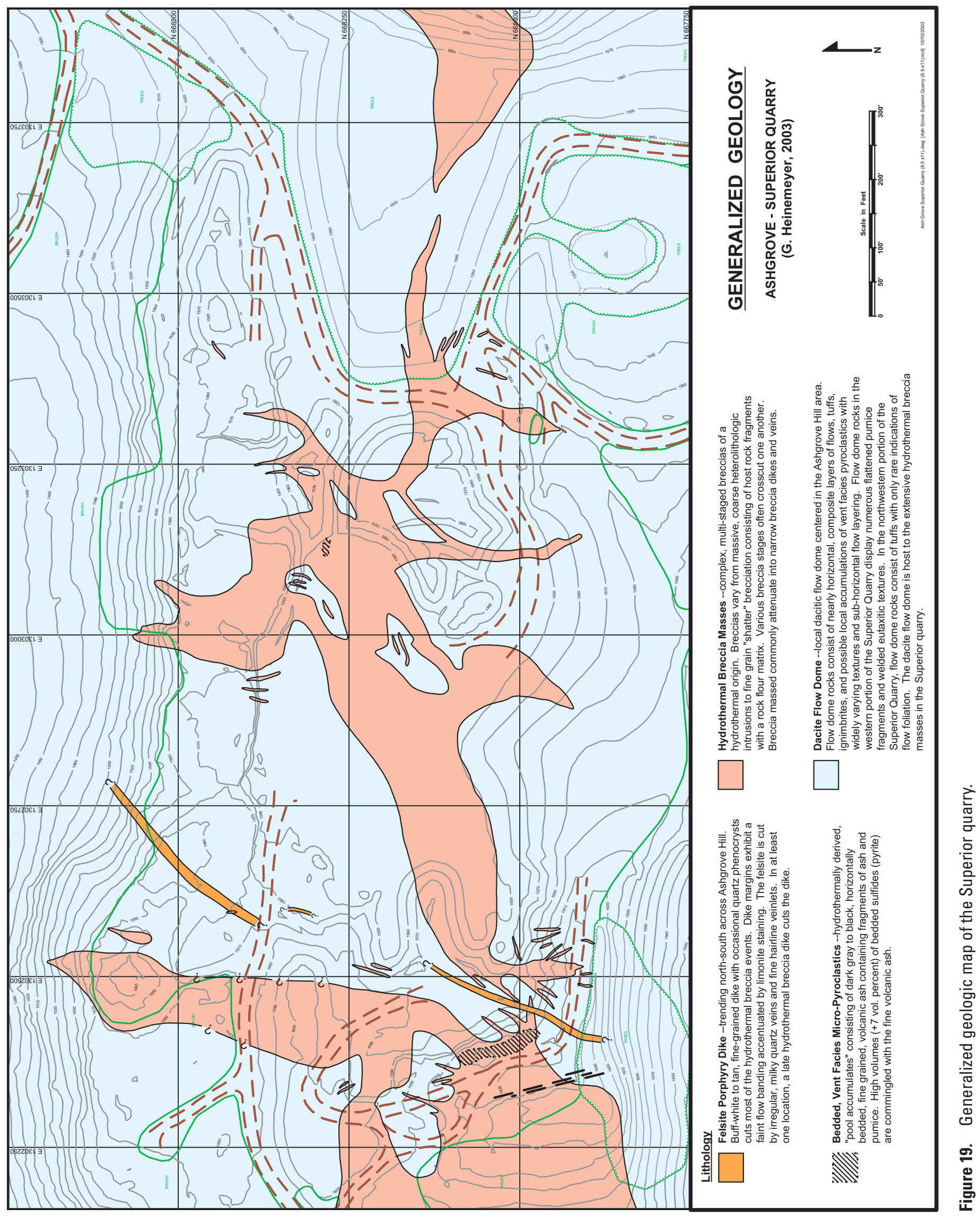




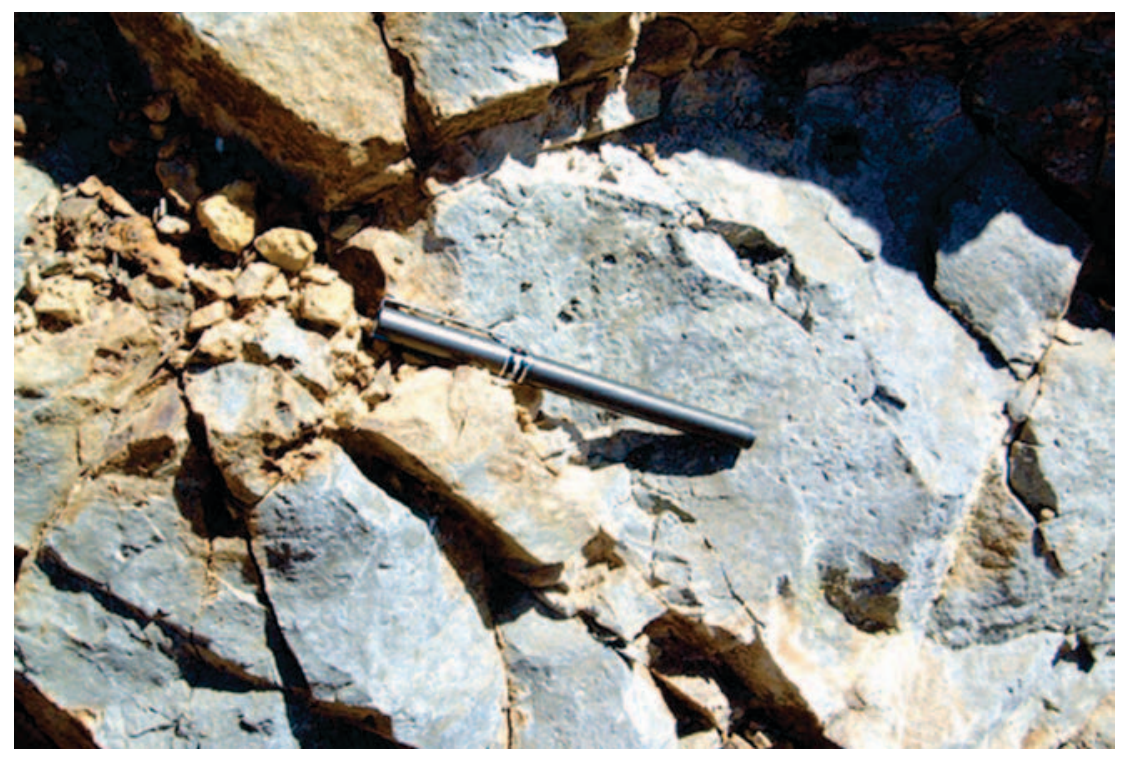

Figure 20. Gray vuggy silica rock with abundant voids after plagioclase and pyroxene phenocrysts in andesite flow. From Superior quarry.

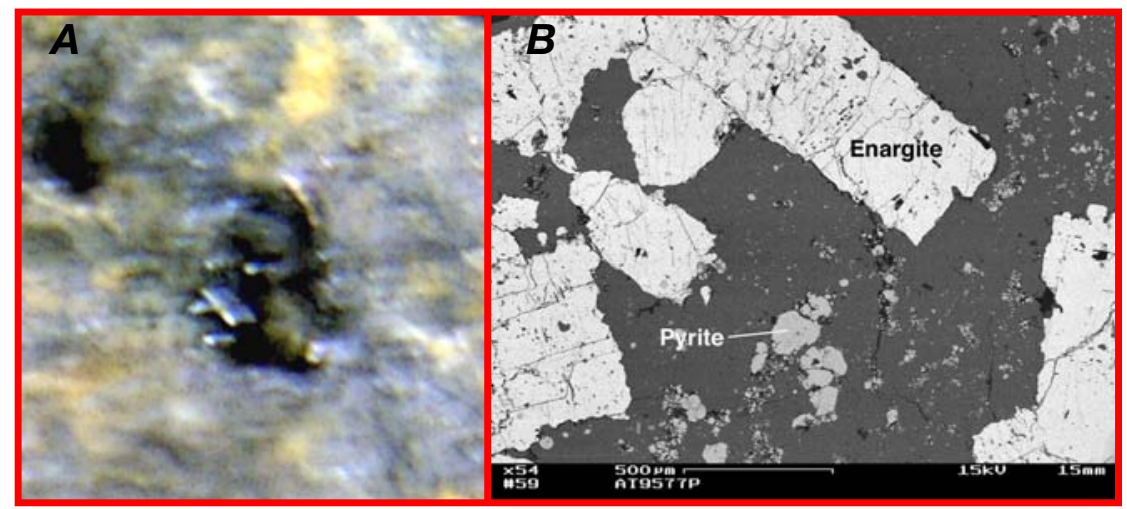

Figure 21. $\quad A$, Enargite crystals in vug and groundmass (gray areas) of vuggy silica rock. Largest crystal is about $5 \mathrm{~mm}$ wide. $B$, Backscattered SEM image of enargite and pyrite crystals in vuggy silica alteration. Samples from Superior quarry.

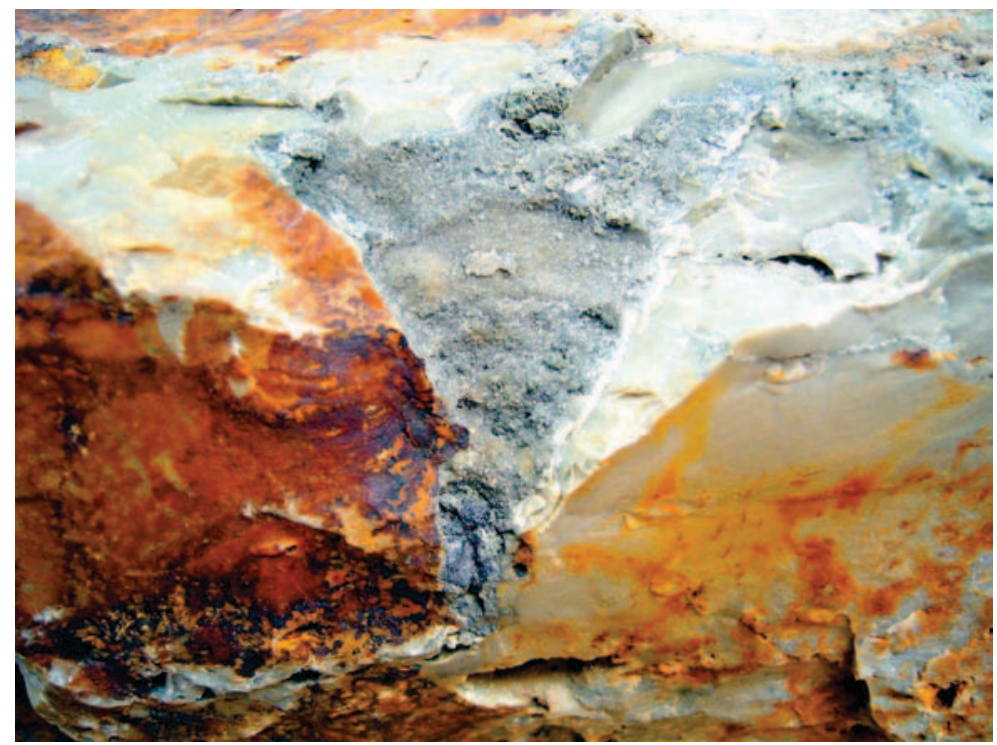

Figure 22. Small dark gray enargite crystals filling funnel-shaped feature (hydrothermal vent?) in white chalcedonic silica, Superior quarry. Cluster of enargite crystals is about $8 \mathrm{~mm}$ wide. 
Field Guide to Hydrothermal Alteration in the White River Altered Area and in the Osceola Mudflow, Washington

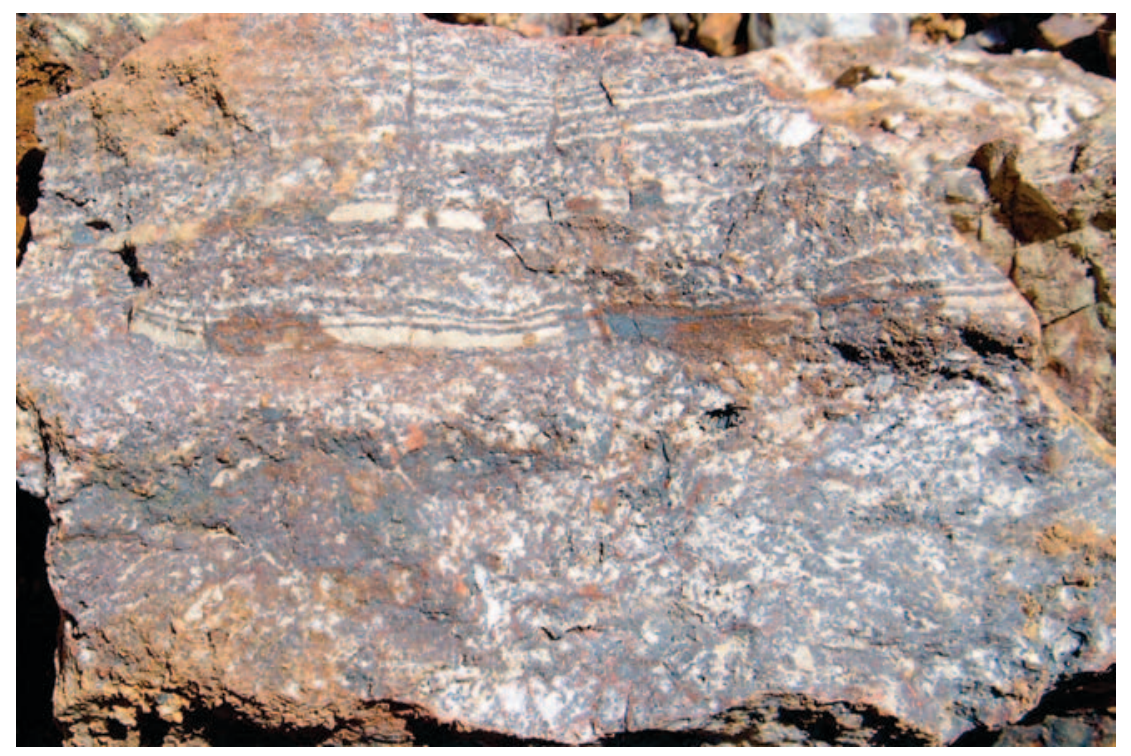

Figure 23. Tan chalcedony replacing relict flow and devitrification layers in dacite flow. Gray areas are hematite after pyrite. Sample is about $15 \mathrm{~cm}$ wide. From the Superior quarry.

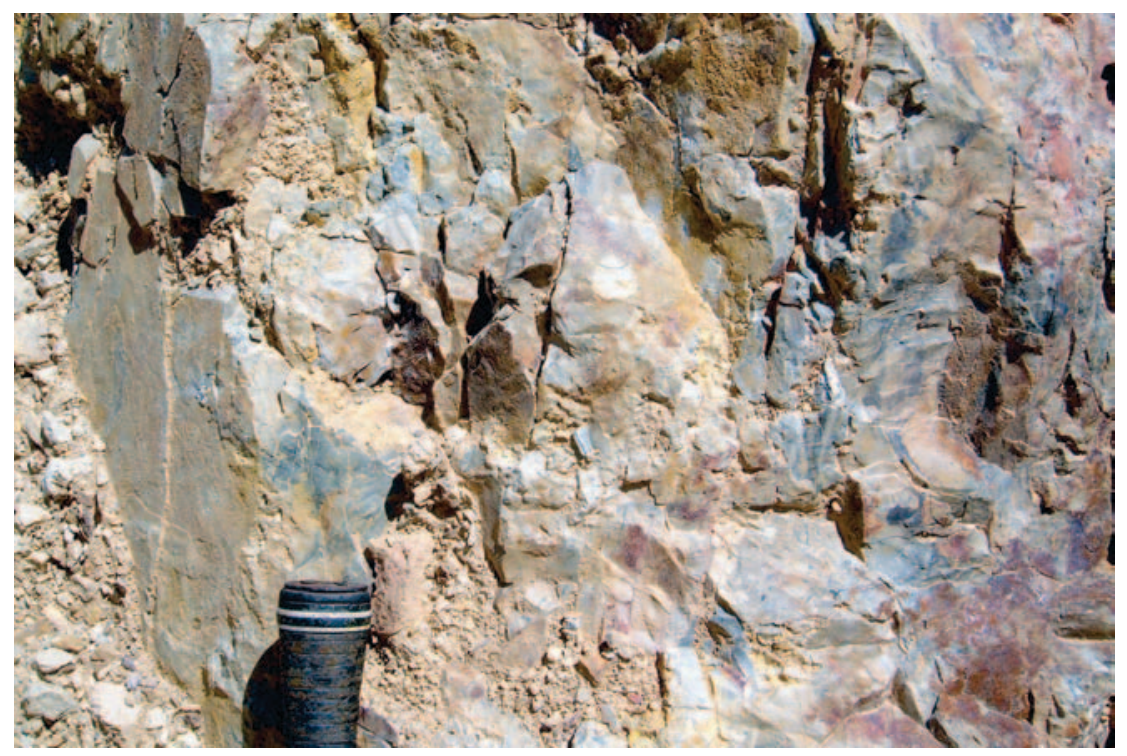

Figure 24. Massive tan chalcedony cut by hydrothermal breccias with sulfide minerals in gray areas. From the Superior quarry.

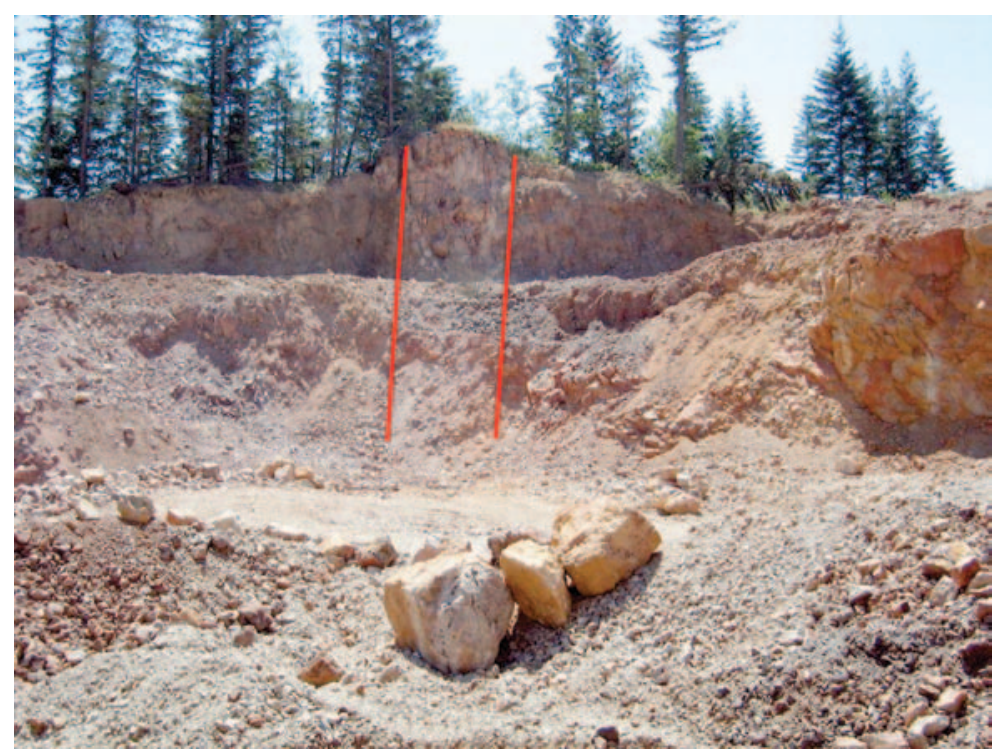

Figure 25. Steeply dipping, quartz-bearing felsic dike cutting dacite in the southwest highwall of the Superior quarry. Dike forms light-colored rocks in the center of the photo (between red lines). 

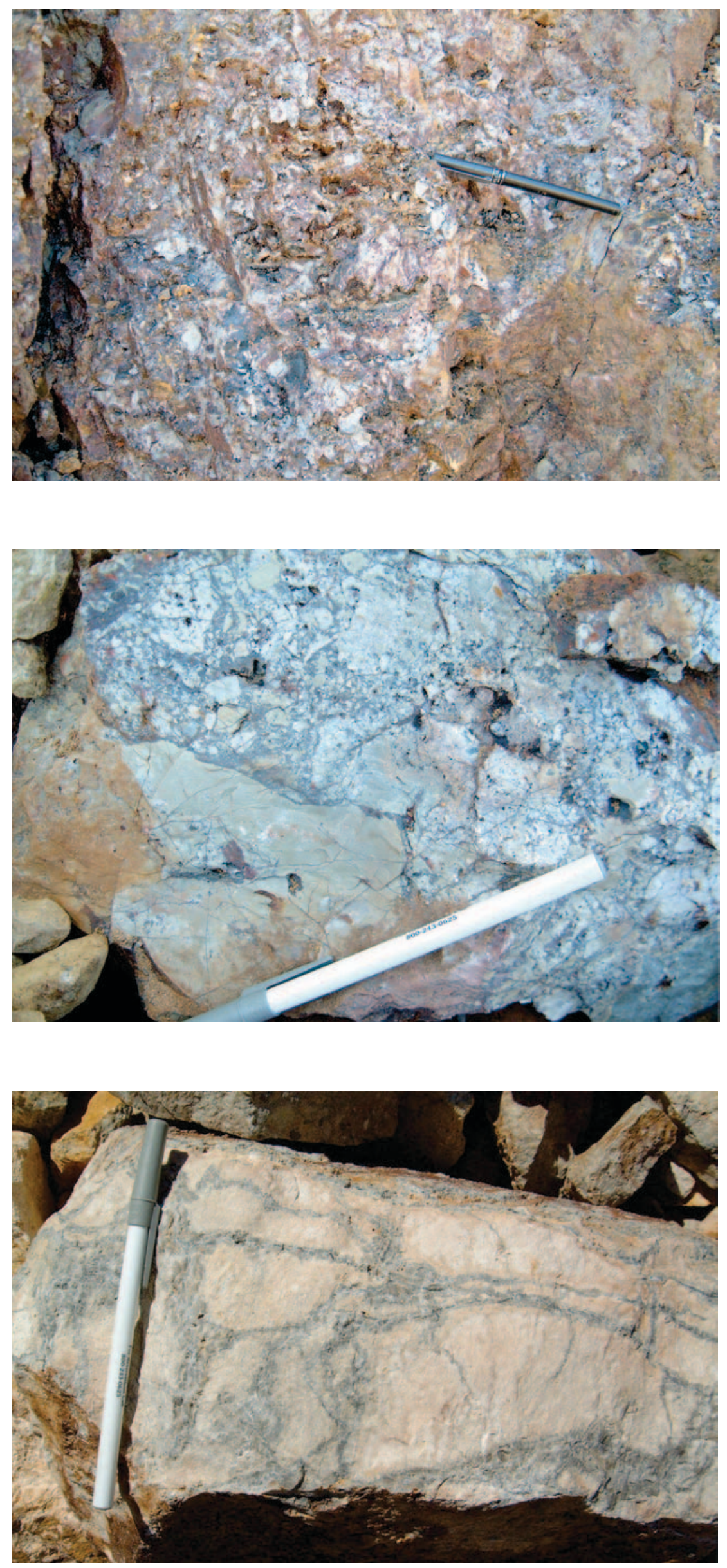

Figure 26. Hydrothermal breccia with clasts of early stage white chalcedony in tan to gray chalcedony with sulfide minerals in gray areas. From the Superior quarry.

Figure 27. Sulfide mineral-bearing hydrothermal breccia developed in massive tan silicified rock in the Superior quarry.

Figure 28. Massive tan silicified dacite tuff(?) cut by stockwork of sulfide mineral-bearing gray chalcedony in the Superior quarry. 

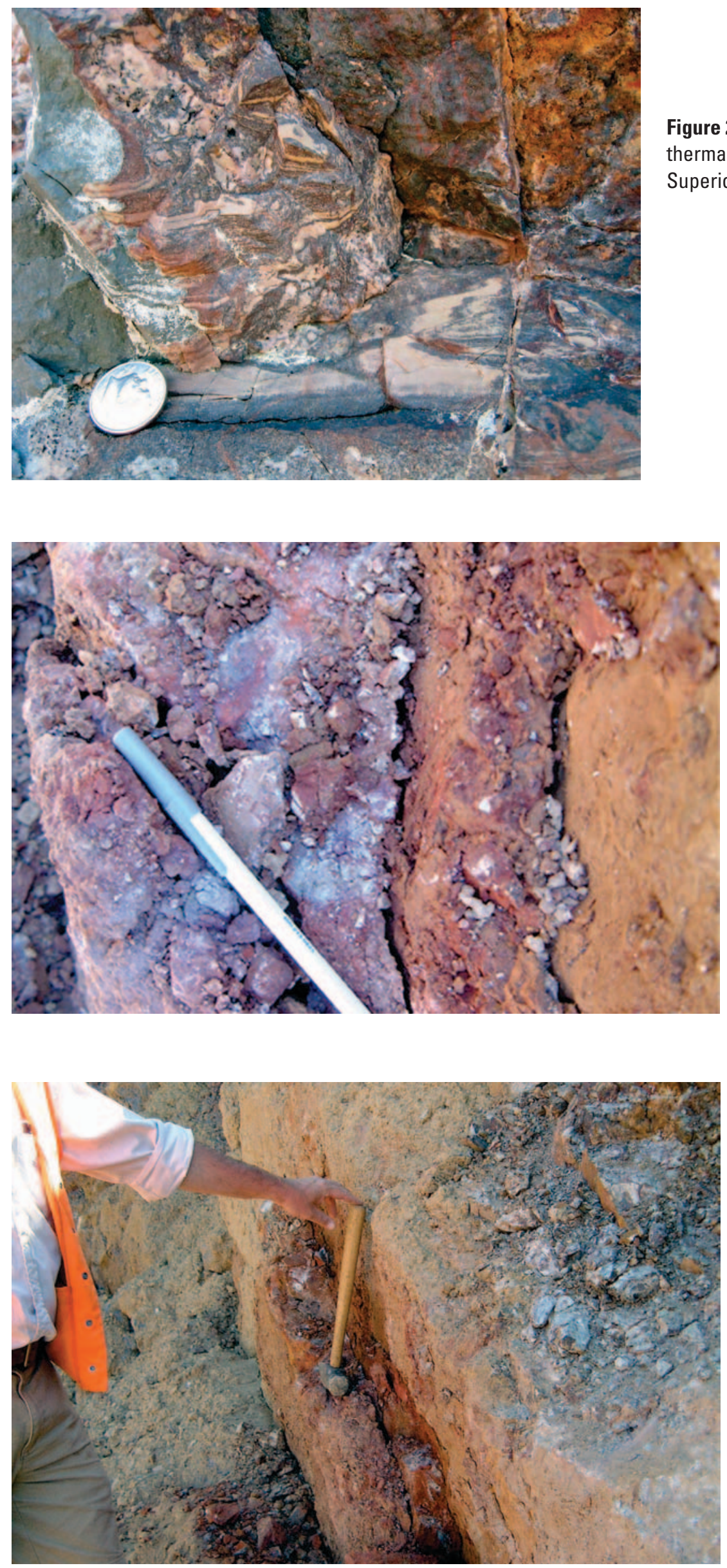

Figure 30. Fault breccia with clay-supported fragments that contains the highest gold content $(1.7 \mathrm{ppm})$ in the Superior quarry.

Figure 31. North-striking fault with red clay gouge developed in massive vuggy silica rock in the Superior quarry. 

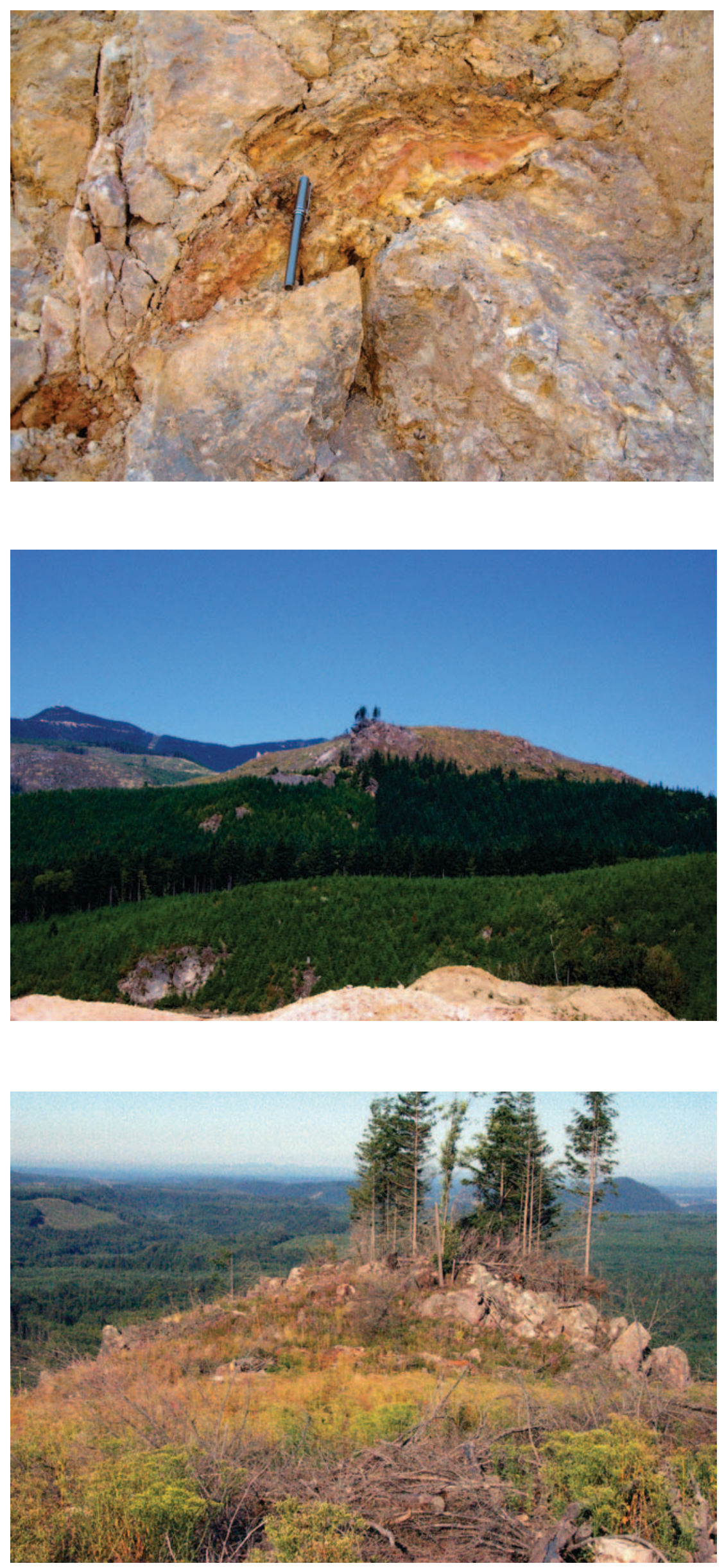

Figure 32. Red to brown smectite clay zone developed from alteration of bedded tuff. Note faults on left and right sides that terminate bedding. From the Superior quarry.

Figure 33. Taugow from the Superior quarry. Outcrops near top of Taugow consist of alunitically-altered tuff breccia. High ridge in background is north of the White River Fault Zone and is underlain by the Oligocene Ohanapecosh Formation.

Figure 34 Knob of alunitic alteration on Taugow. Rocks are probably tuff and tuff breccia now replaced by pale pink alunite and fine-grained white silica. White River Valley in distance. 

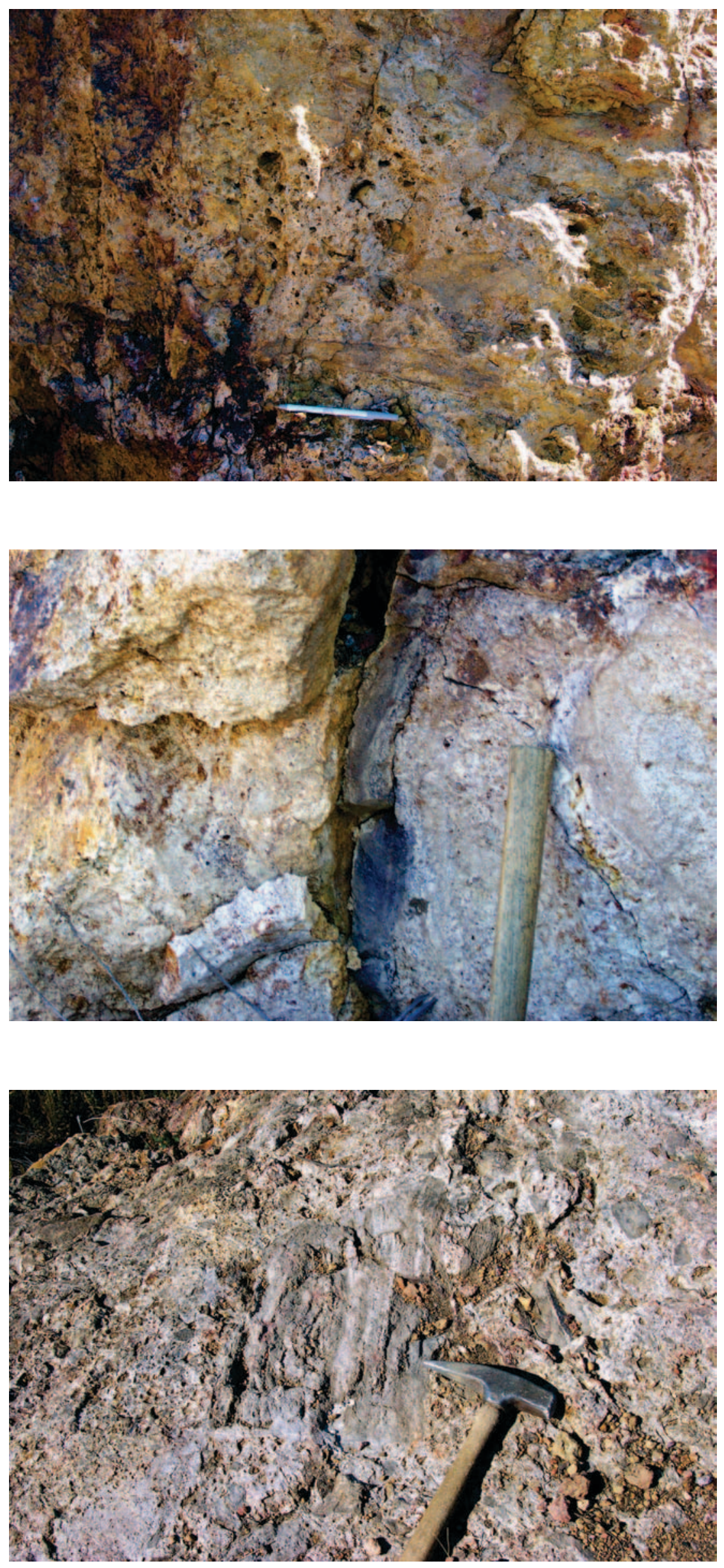

Figure 35. Leached silicified tuff breccia with relict pyroclastic textures exposed in roadcut near top of Taugow.

Figure 36. Narrow fine-grained silicic dike cutting silicified tuff breccia near top of Taugow.

Figure 37. Blocks of vuggy silica alteration in hydrothermal breccia near top of Taugow. Largest block shows relict flow banding or bedded tuffaceous texture. Breccia matrix consists of fine-grained silica and hematite. 


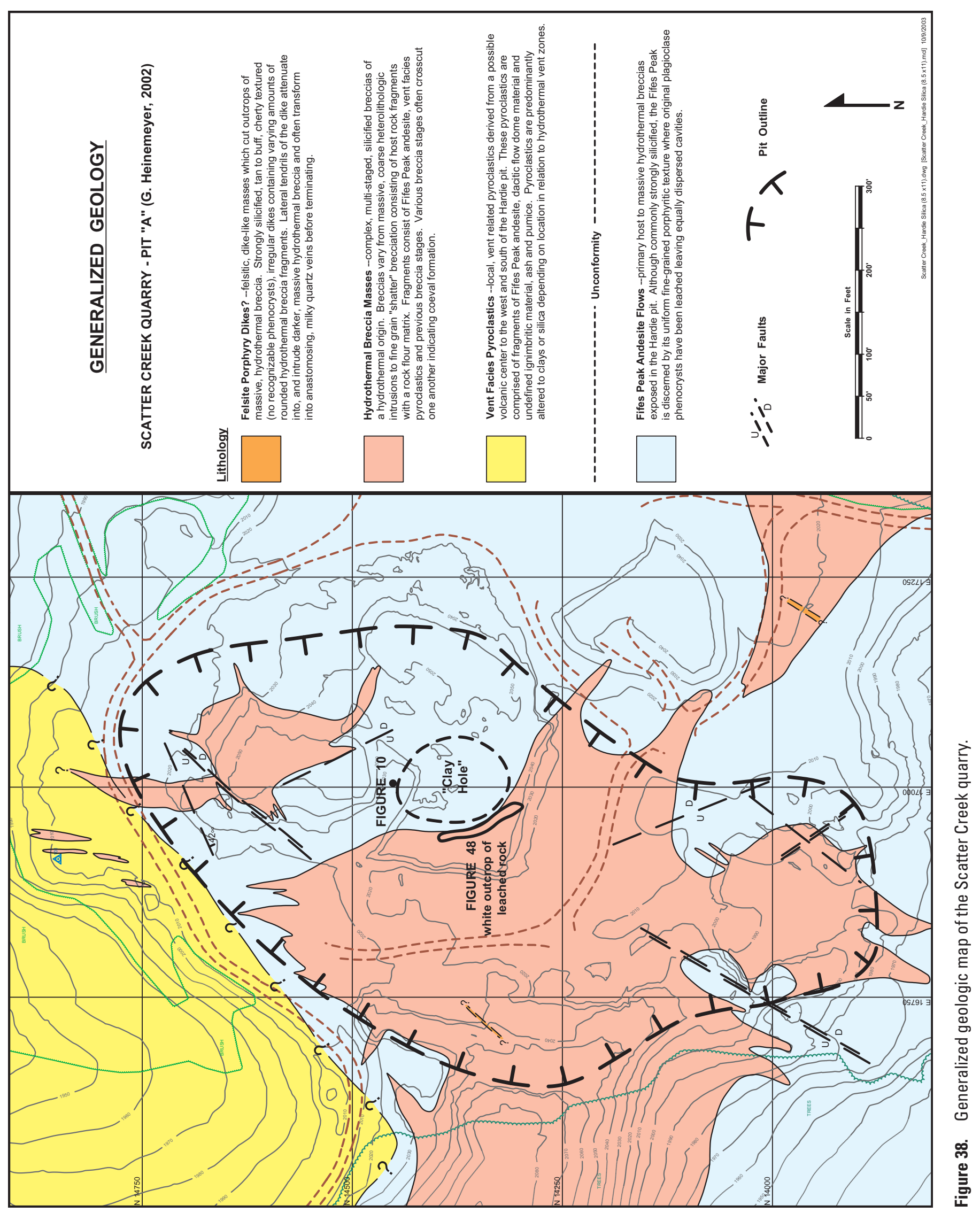


Field Guide to Hydrothermal Alteration in the White River Altered Area and in the Osceola Mudflow, Washington

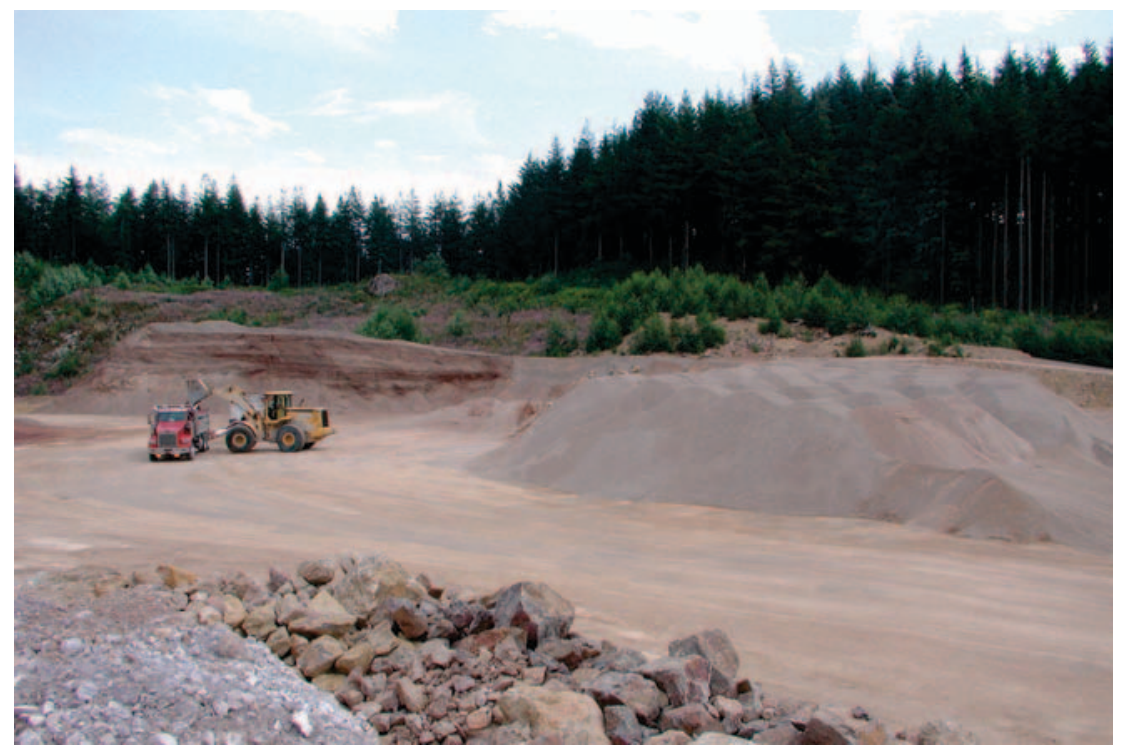

Figure 39. Stockpile of sized silica at Scatter Creek quarry being loaded for shipment to James Hardie Building Products, Inc., for use in producing fiber cement-based building products.

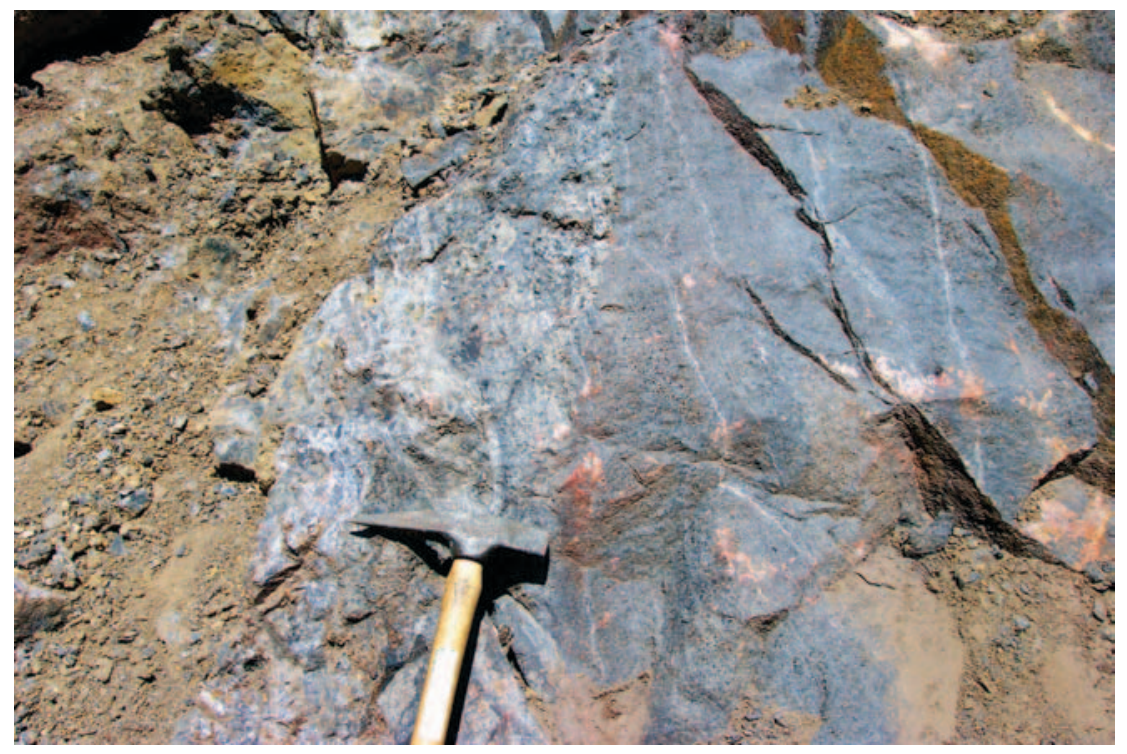

Figure 40. Gray vuggy silica replacing porphyritic andesite cut by white quartz and chalcedony veins and hydrothermal breccias. From the Scatter Creek quarry.

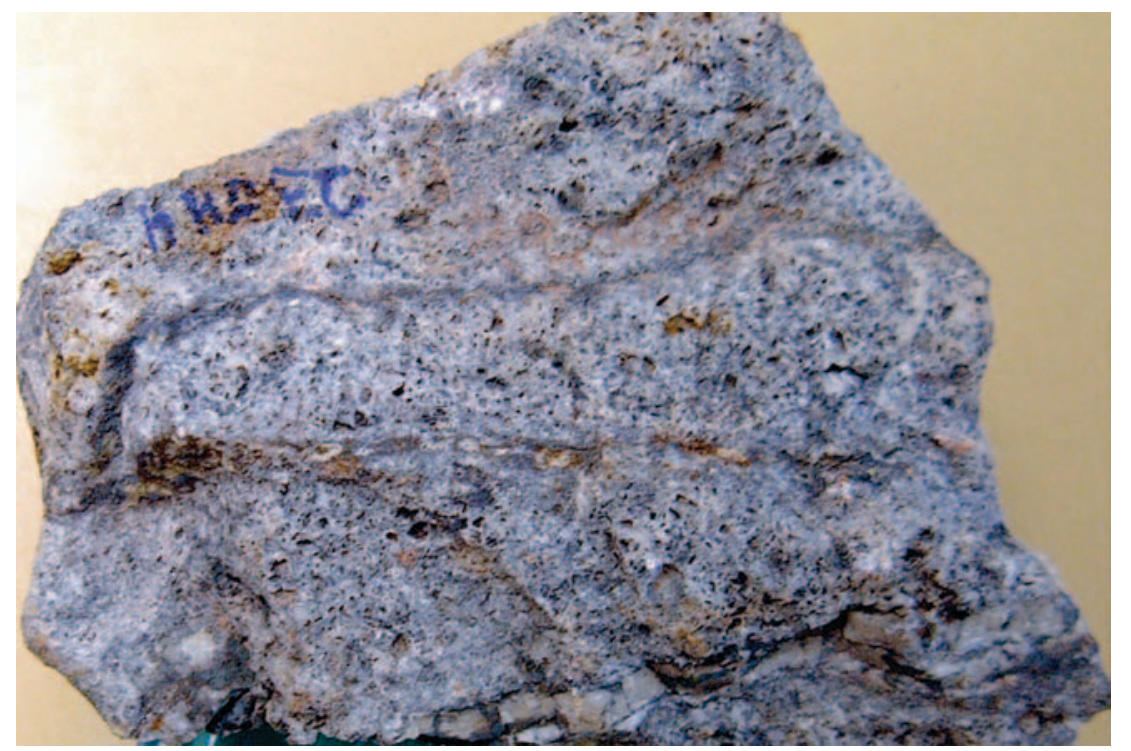

Figure 41. Voids developed in porphyritic andesite after leached plagioclase and pyroxene phenocrysts by acid hydrothermal fluids leaving a residual ground mass of silica. Tan chalcedonic veins cut the vuggy silica. Label is about $4 \mathrm{~cm}$ wide. From the Scatter Creek quarry. 


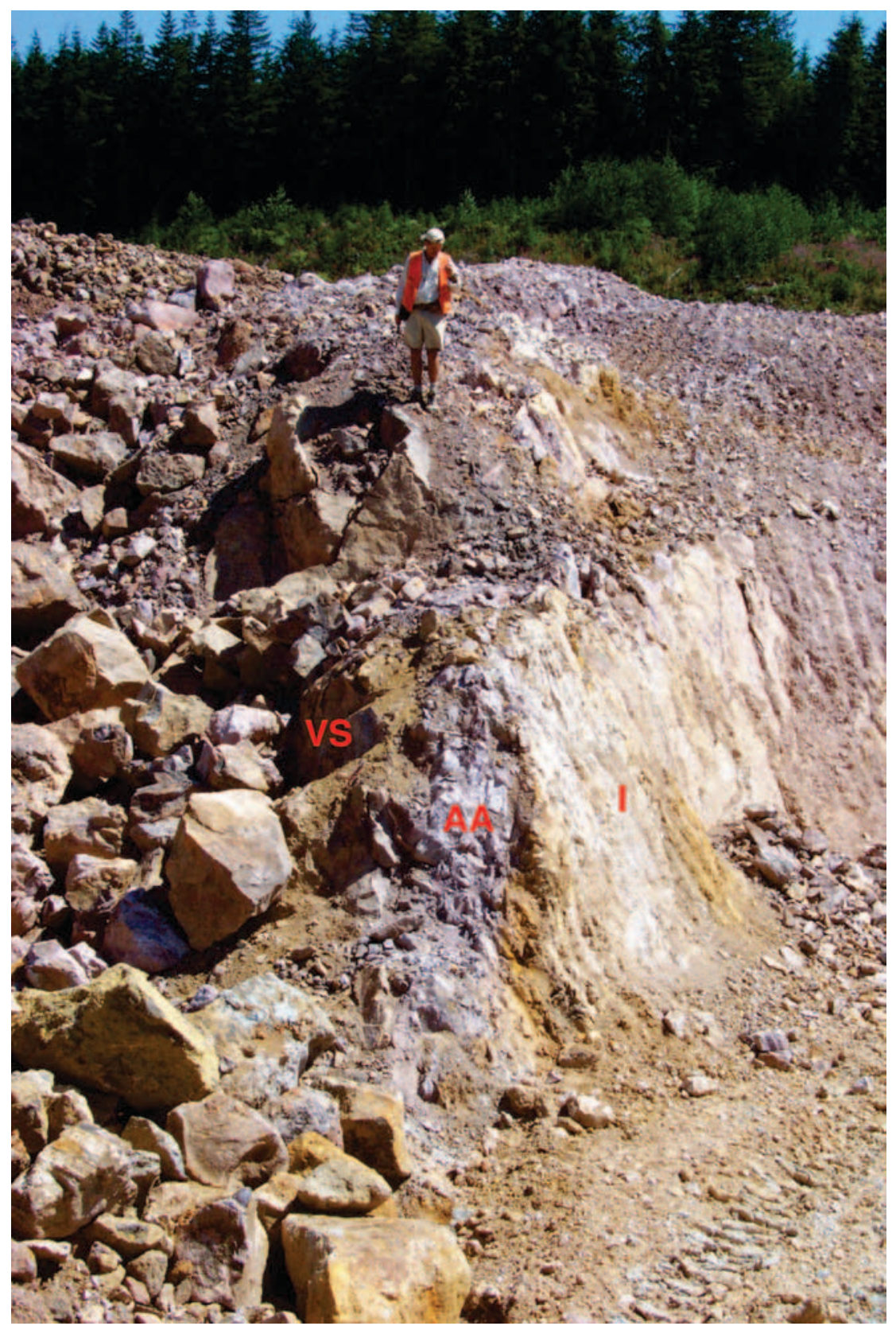

Figure 42. Northeast-trending rib of orangish-brown vuggy silica alteration (VS) bordered by light-colored alunitic (AA) and illitic (I) alteration localized along fault zone in Scatter Creek quarry.

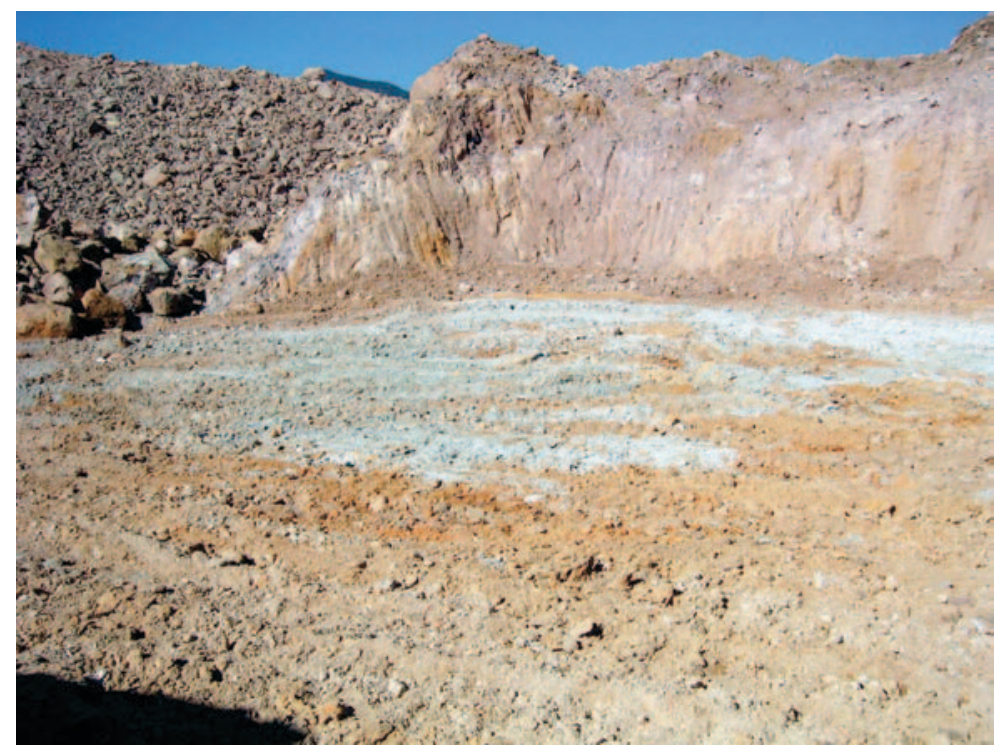

Figure 43. "Clay Hole" (fig. 38). South side of northeasttrending rib of vuggy silica alteration (fig. 42) consisting of reddish colored illitic alteration and pale green chloritemontmorillonite-rich propylitic alteration that forms floor of the Scatter Creek quarry. 
Field Guide to Hydrothermal Alteration in the White River Altered Area and in the Osceola Mudflow, Washington

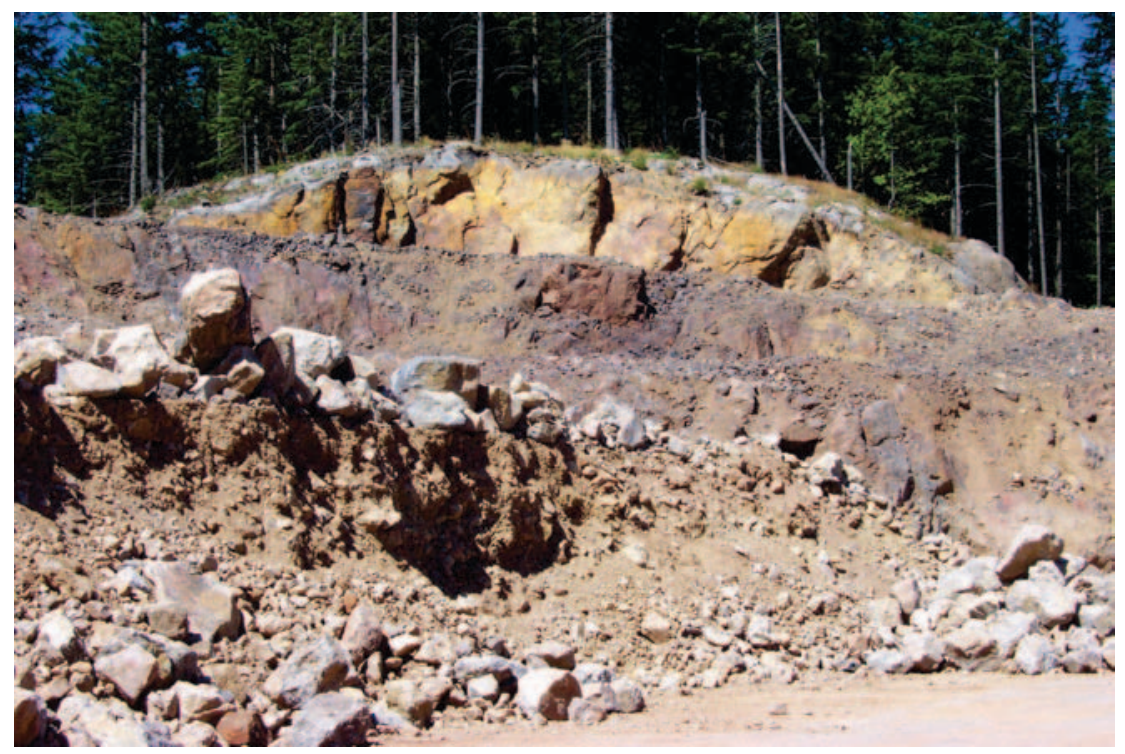

Figure 44. Oxidation in the Scatter Creek quarry. Leaching of hematite from vuggy silica in the near surface forms a white vuggy silica rock that is underlain by gray to brown vuggy silica with abundant hematite. Relict pods of pyrite-rich alteration indicate that hematite is replacing pyrite.

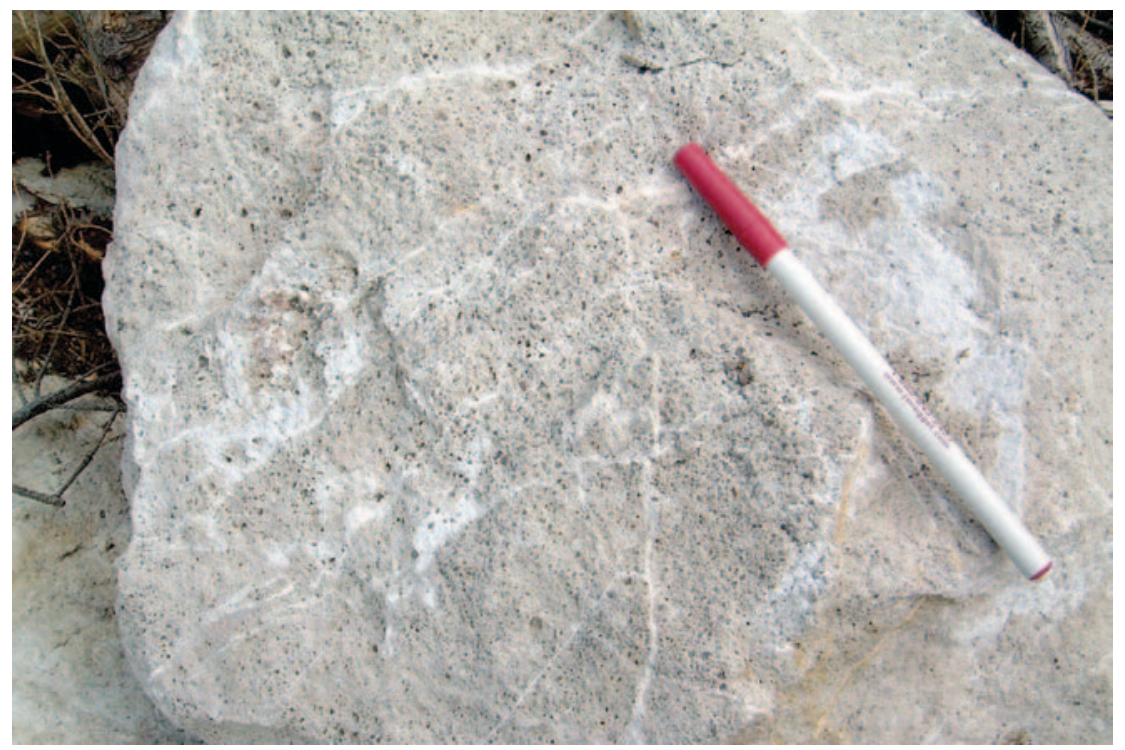

Figure 45. Vuggy silica cut by early stage of white chalcedonic hydrothermal breccia and veins. From the Scatter Creek quarry. 

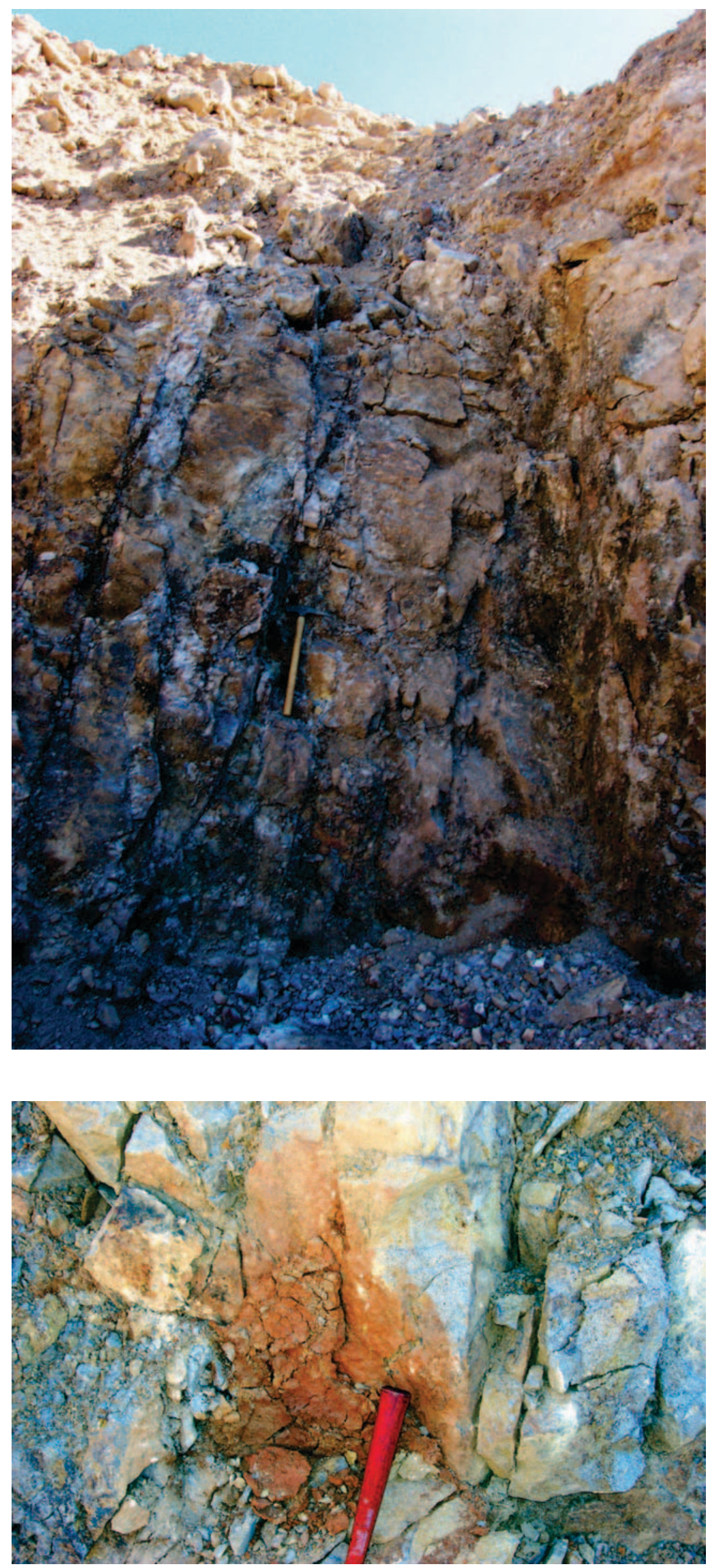

Figure 46. Vuggy silica in andesite cut by hydrothermal breccias with tan chalcedony matrix and hematite after pyrite and associated chalcedony and quartz veins. From the Scatter Creek quarry.

Figure 47. Fracture in vuggy silica filled with late-stage hydrothermal red clay composed of hematite, smectite, and dickite and commonly having elevated concentrations of $\mathrm{Au}, \mathrm{As}, \mathrm{Sb}$, and $\mathrm{Hg}$. From the Scatter Creek quarry. 


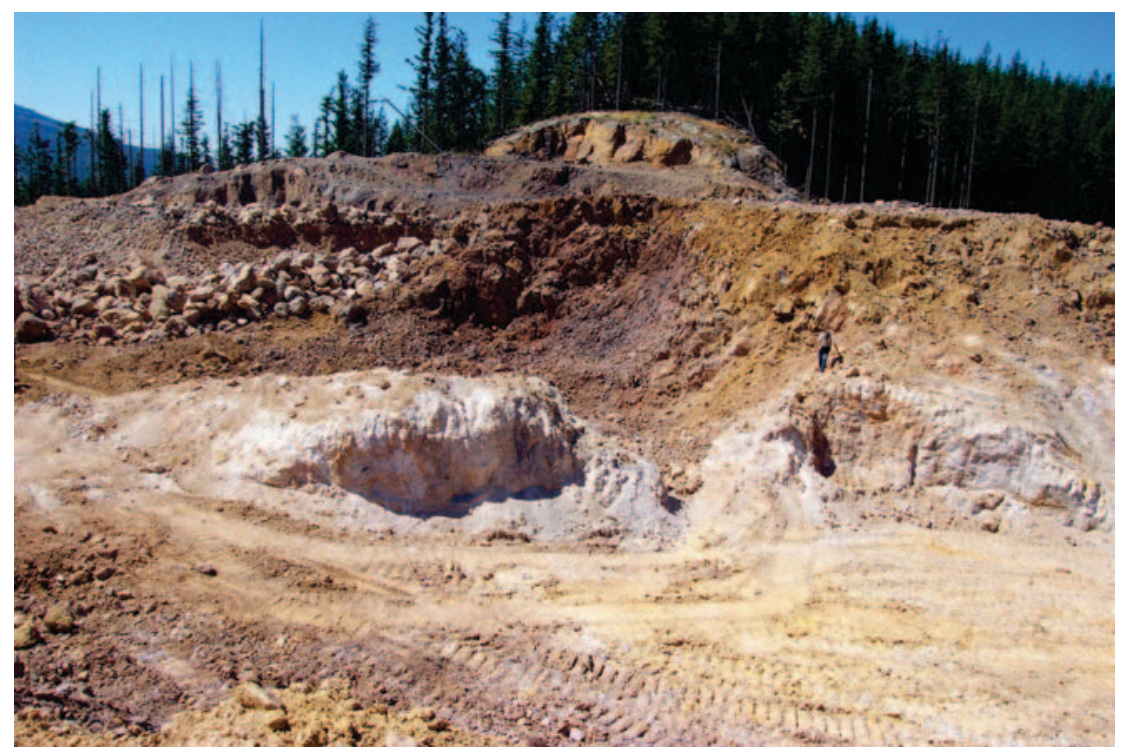

Figure 48. White outcrops of leached rock that formed in the near-surface steam-heated zone. Altered rocks in background are densely silicified and formed below the paleo ground water table in the upper part of the hydrothermal system. See figure 38 for outcrop location.

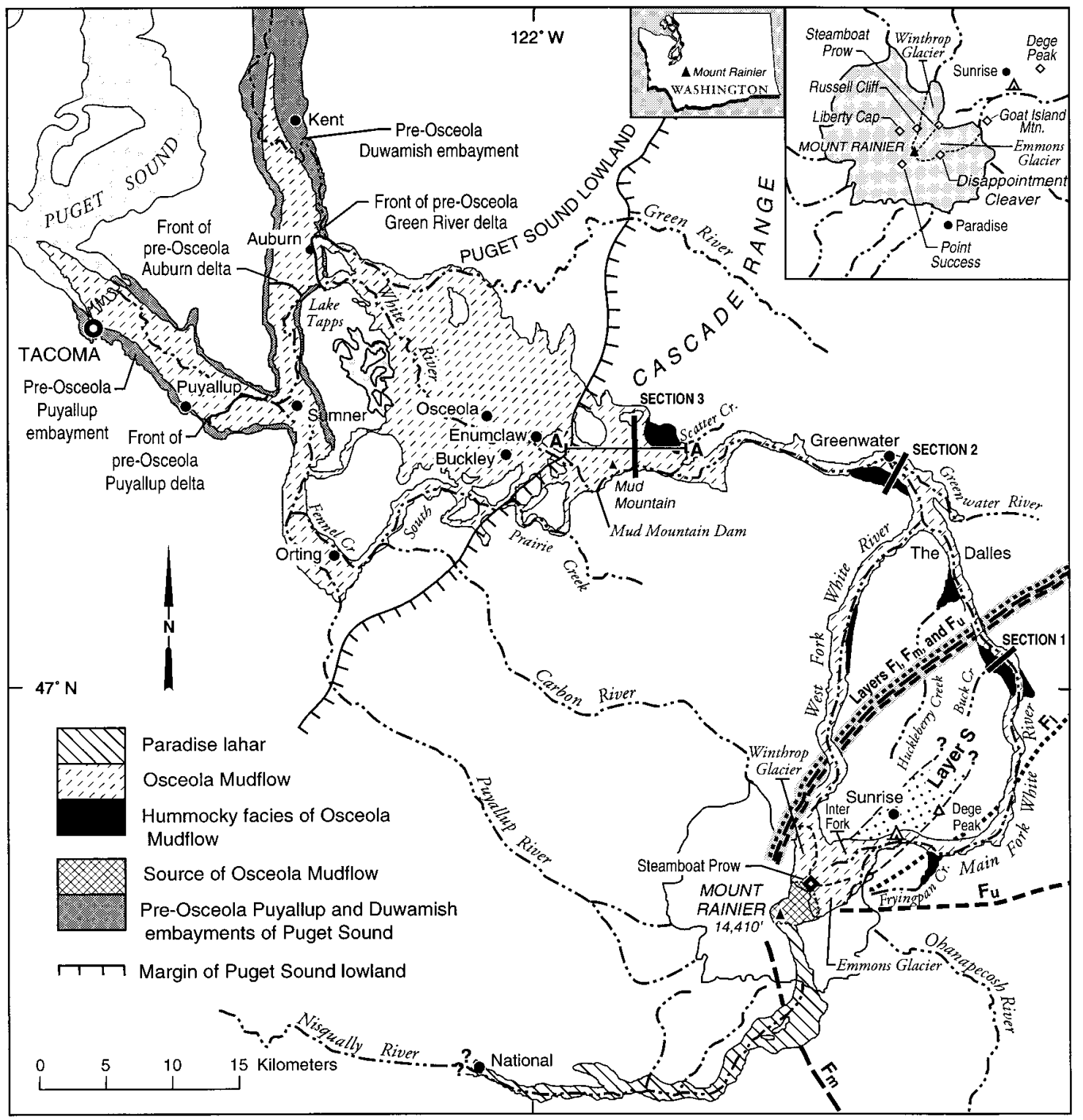

Figure 49. Map showing distribution of Osceola Mudflow and Paradise lahar (modified from Crandell, 1971, plate 3). Distribution of Osceola Mudflow in subsurface from Dragovich and others (1994). Distributions of tephra layers $F$ and $S$ (Mullineaux,1974) shown near Mount Rainier. Figure reproduced from Vallance and Scott (1997, fig. 1). 

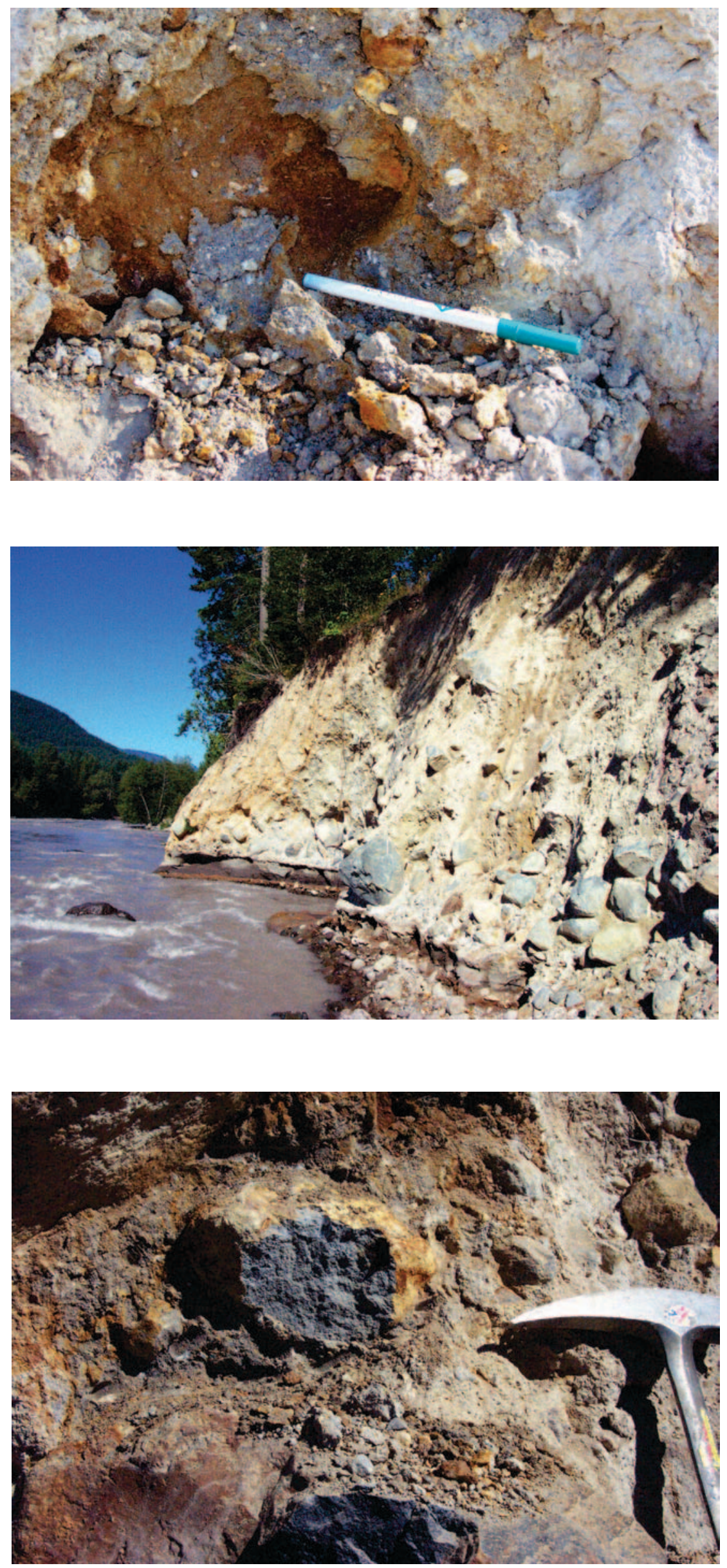

Figure 50. Dark-gray clay-pyrite rich matrix of the Osceola Mudflow near Greenwater. Orange color due to surface oxidation of pyrite that extends a few $\mathrm{cm}$ or less below the outcrop surface. Small white clasts are advanced argillic alteration.

Figure 51. Typical outcrop of the Osceola Mudflow along the White River near Greenwater. Osceola Mudflow is about $8 \mathrm{~m}$ thick. The characteristic pale yellow color is due to surficial weathering of pyrite in clay-rich matrix. The Osceola Mudflow here overlies about $1 \mathrm{~m}$ of gray compact silt, sand and angular pebbles and sparse cobbles, which is a runout facies of lahars (LRO) that were associated with eruptions at Mount Rainier between 6,000 and 6,400 radiocarbon years ago $(6,700$ and 7,400 calendar years B.P.). The gray LRO, in turn, overlies stream gravel (reddish-brown unit right at river level).

Figure 52. Typical smectite-pyrite alteration of andesite clast in the Osceola Mudflow near Greenwater. Clast has a narrow oxidation (weathering) rind surrounding rock with unoxidized disseminated and vesicle filling pyrite. 
Field Guide to Hydrothermal Alteration in the White River Altered Area and in the Osceola Mudflow, Washington

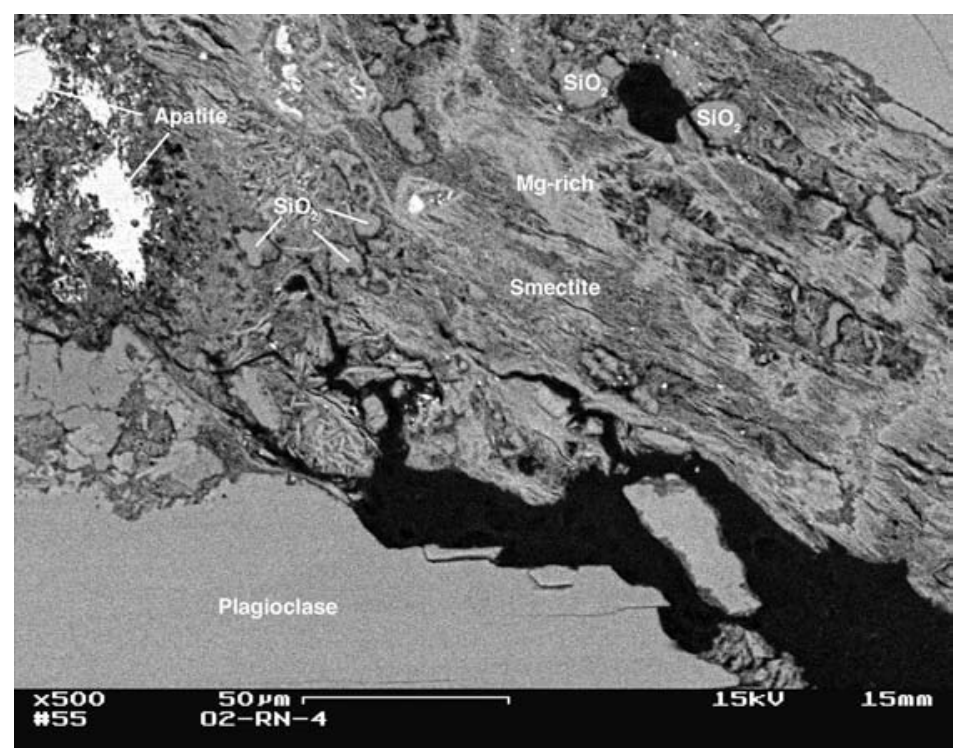

Figure 53. Back-scattered SEM image of smectite alteration of andesite clast in the Osceola Mudflow. Plagioclase phenocrysts are relatively unaltered.

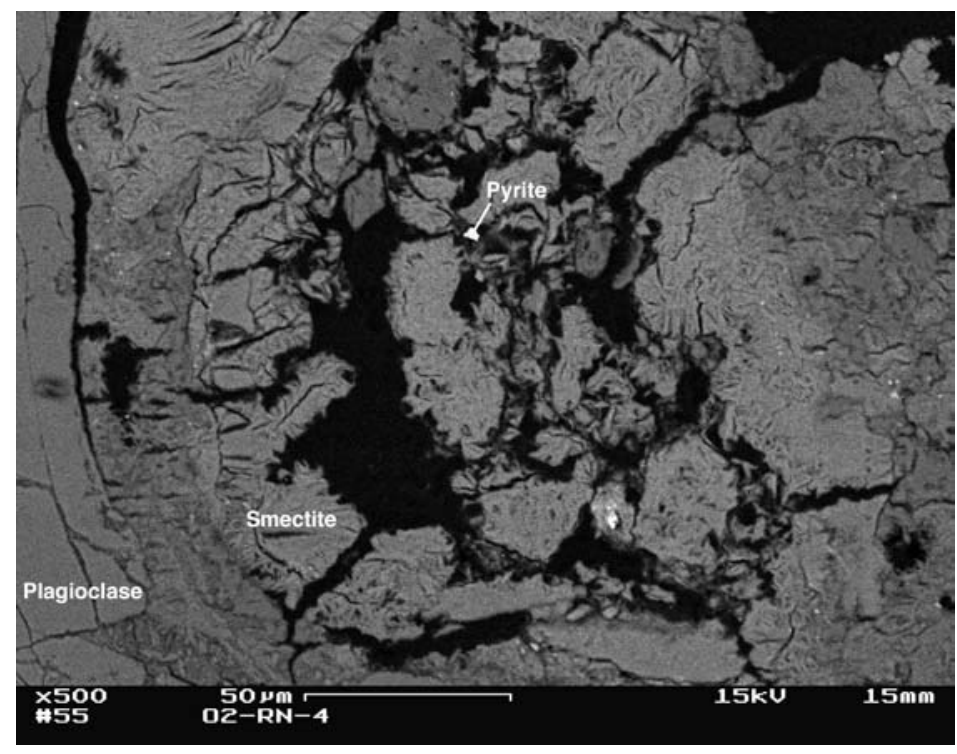

Figure 54. Back-scattered SEM image of smectite-pyrite alteration of andesite clast in the Osceola Mudflow. Plagioclase phenocrysts are relatively unaltered.

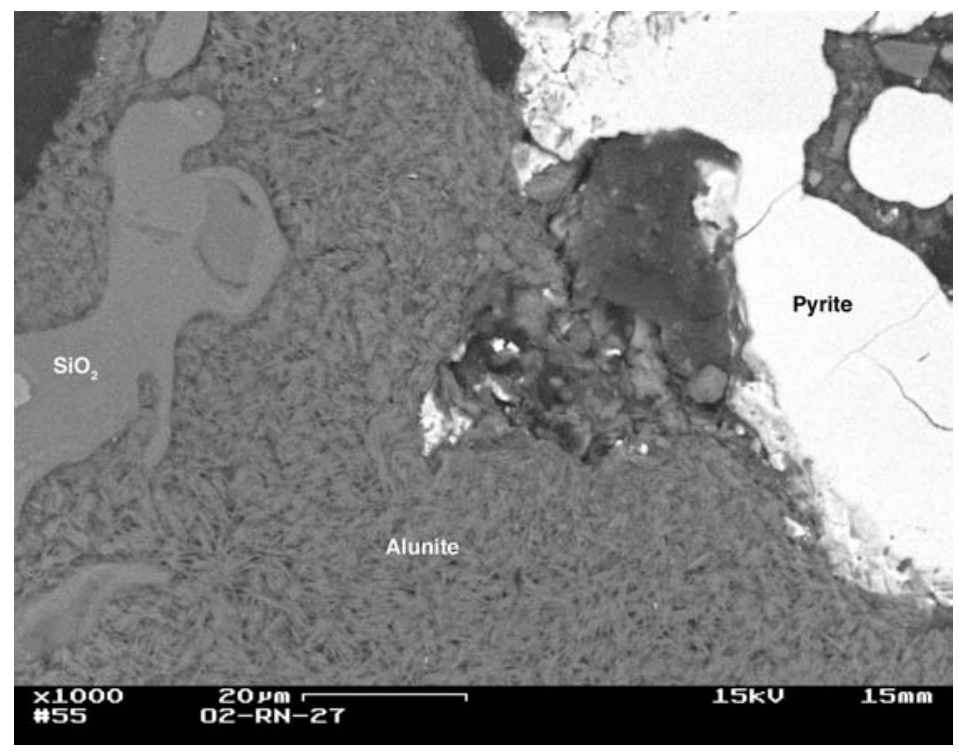

Figure 55. Back-scattered SEM image of alunite, opaline silica (SiO2), and pyrite in advanced argillic altered clast in the Osceola Mudflow. 

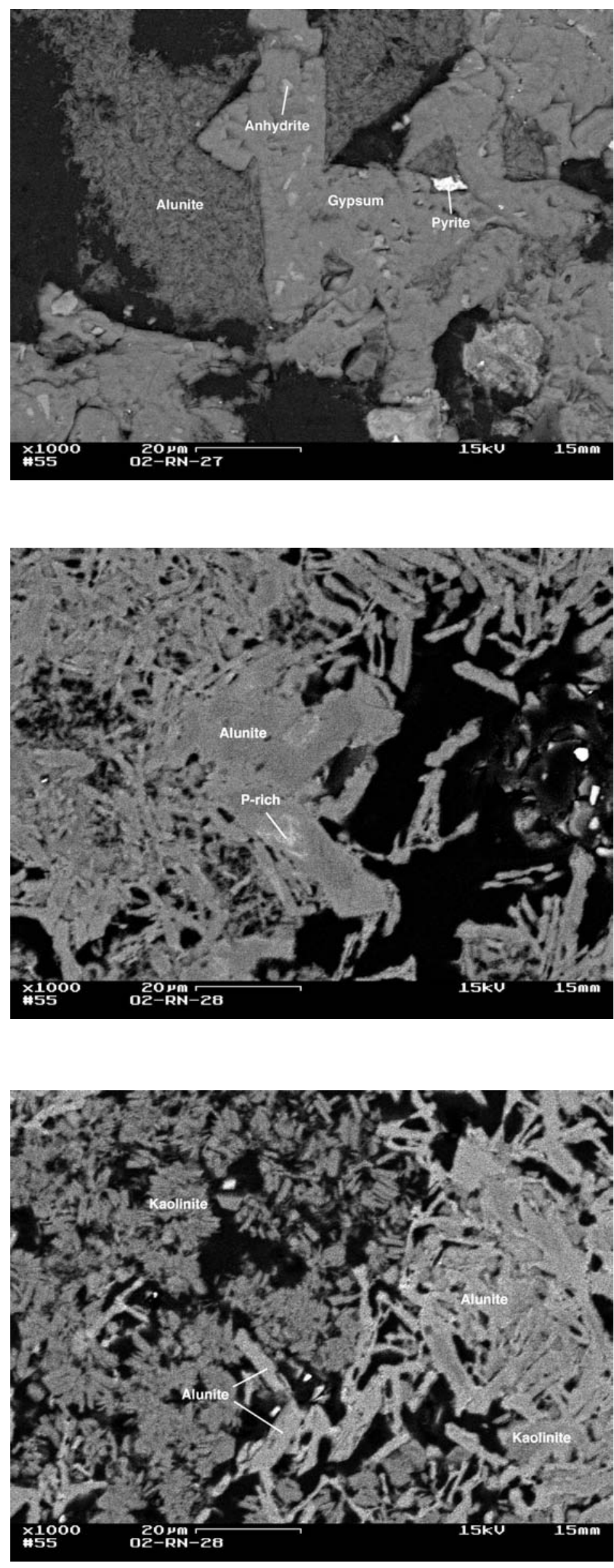

Figure 56. Back-scattered SEM image of alunite, anhydrite/ gypsum, and pyrite in advanced argillic altered clast in the Osceola Mudflow.
Figure 57. Back-scattered SEM image of alunite containing P-rich domains in advanced argillic altered clast in the Osceola Mudflow.
Figure 58. Back-scattered SEM image of intergrown alunite and kaolinite in advanced argillic altered clast in the Osceola Mudflow. 
Field Guide to Hydrothermal Alteration in the White River Altered Area and in the Osceola Mudflow, Washington

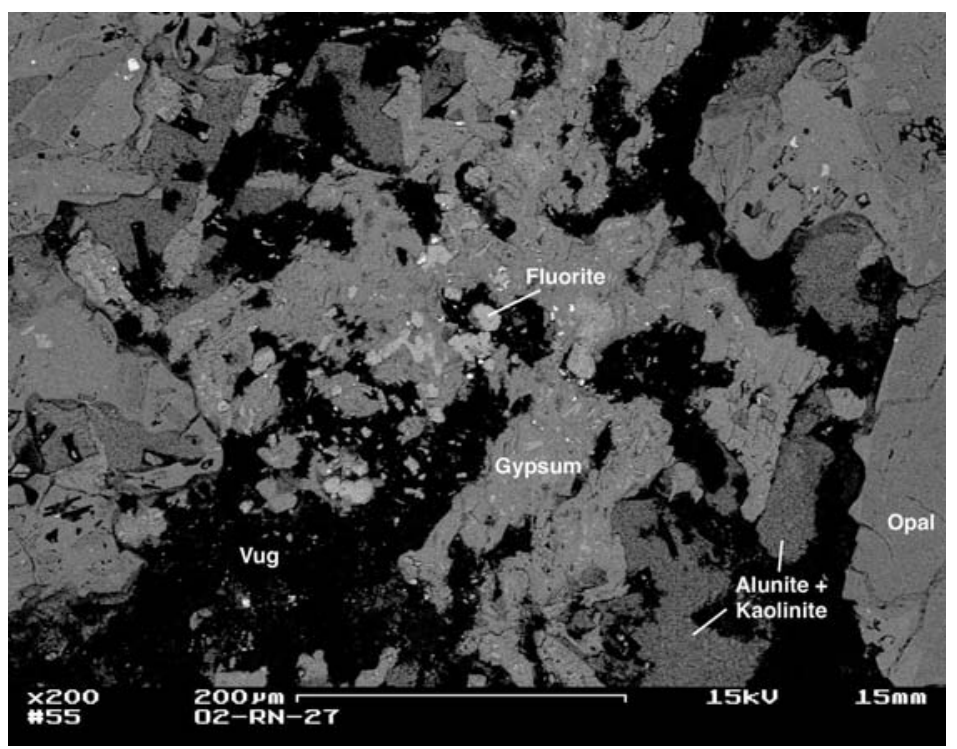

Figure 59. Back-scattered SEM image of vug-filling anhydrite/gypsum and fluorite in advanced argillic altered clast in the Osceola Mudflow.

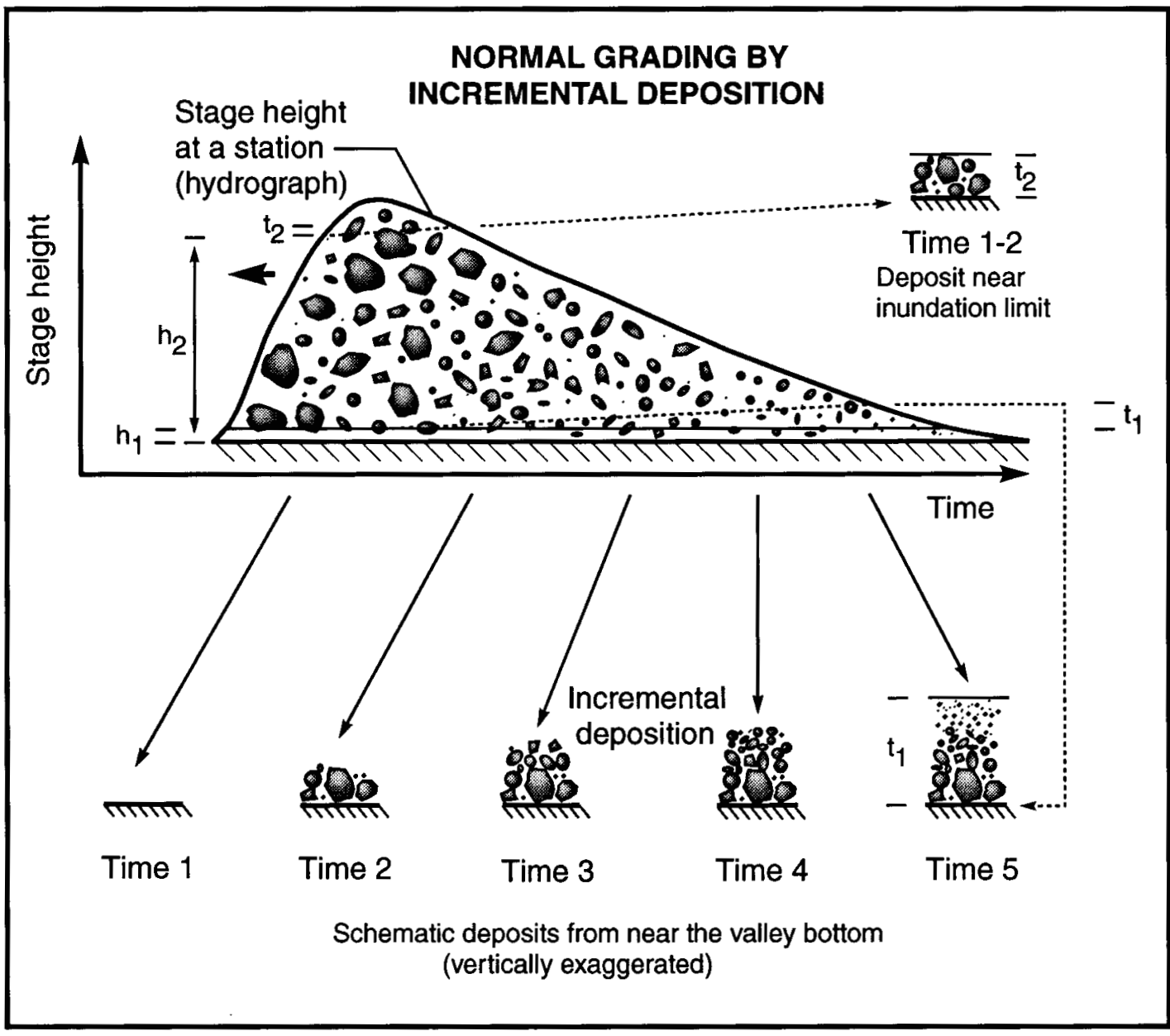

Figure 60. Schematic diagram of stage height versus time (hydrograph) for mass flow at point in bottom of valley, and depositional sequence of flow illustrating incremental deposition model for explaining normal grading. Deposition illustrated for two stations 1 and 2 at heights $\mathrm{h} 1$ and $\mathrm{h} 2$ above valley bottom and with ultimate thicknesses $\mathrm{t} 1$ and $\mathrm{t} 2$. Short dashed lines through hydrograph indicate uniform incremental deposition. Sense of motion of mass flow is to left. See text for explanation. Figure reproduced from Vallance and Scott (1997, fig. 13). 

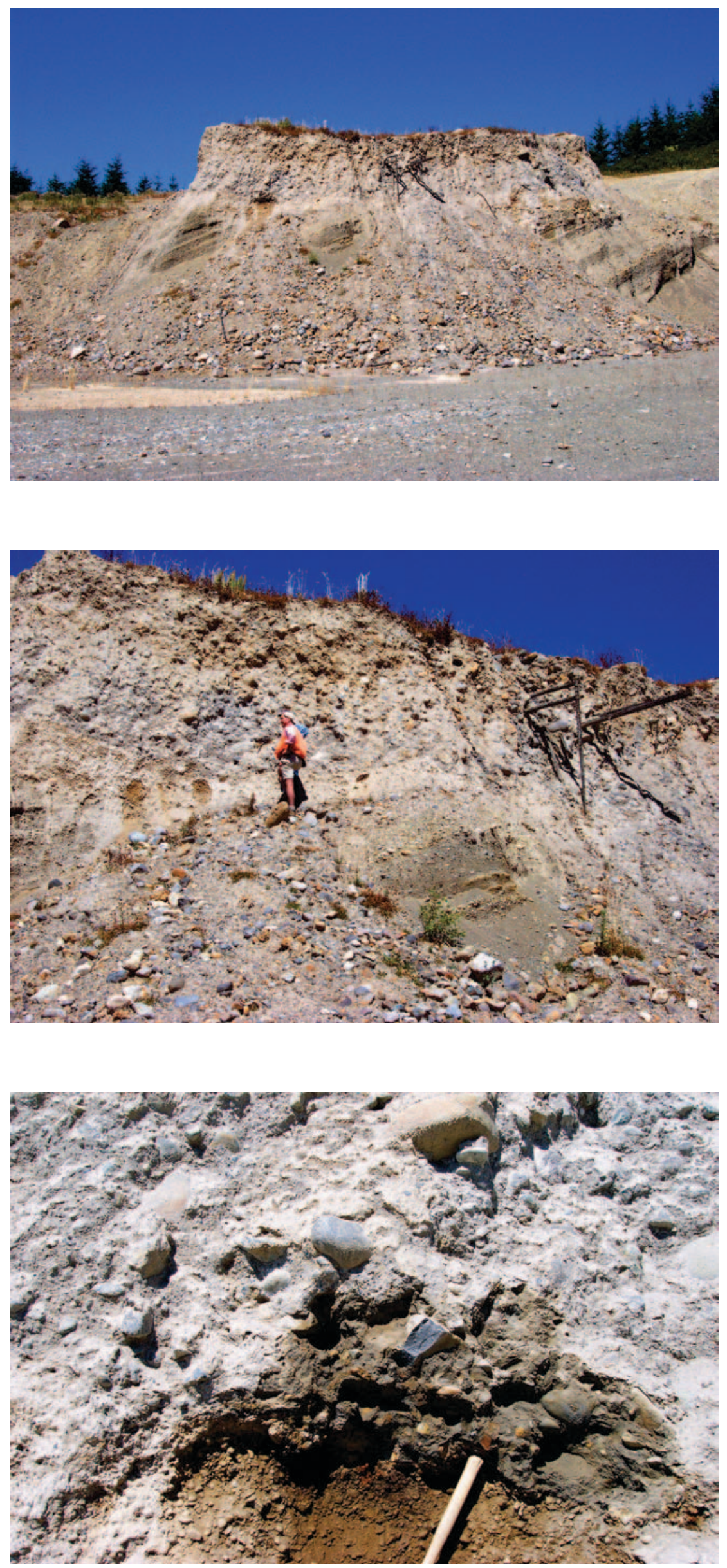

Figure 61. Exposure of Osceola Mudflow overlying well bedded late Pleistocene glacial-fluvial deposits in the Corliss quarry. Note dark gray trees protruding from the center of the Osceola Mudflow. Figure 62. Partly charred trees protruding from the Osceola Mudflow in the Corliss quarry. Note generally rounded cobbles up to 50 $\mathrm{cm}$ in the Osceola.

Figure 62. Partly charred trees protruding from the Osceola Mudflow in the Corliss quarry. Note generally rounded cobbles up to $50 \mathrm{~cm}$ in the Osceola.

Figure 63. Base of the Osceola Mudflow in the Corliss quarry. Note dark orange, iron rich hard pan forming beneath the Osceola and well rounded clasts in the 0 sceola. 
Field Guide to Hydrothermal Alteration in the White River Altered Area and in the Osceola Mudflow, Washington

Table 1. Hydrothermal alteration assemblages in the White River altered area defined by Portable Infrared Mineral Analyzer (PIMA) analyses.

\begin{tabular}{|c|c|c|}
\hline $\begin{array}{l}\text { Alteration type } \\
\text { (fig. 8) }\end{array}$ & Mineral assemblage $^{1}$ & Occurrence \\
\hline Silica & $\begin{array}{l}\text { Quartz, cristobalite, and (or) } \\
\text { chalcedony } \pm \text { pyrite }\end{array}$ & $\begin{array}{l}\text { Silicified zones (fig. 8), including vuggy } \\
\text { silica }\end{array}$ \\
\hline Alunite & Quartz + alunite \pm pyrite & $\begin{array}{l}\text { Silicified zones and fringing silicified } \\
\text { zones (fig. 8) }\end{array}$ \\
\hline Dickite & Quartz + dickite \pm pyrite & Fringing silicification \\
\hline Illite & Quartz + illite + pyrite & $\begin{array}{l}\text { Fringing silicification and transitional to } \\
\text { propylitic alteration }\end{array}$ \\
\hline Kaolinite & Quartz + kaolinite \pm pyrite \pm alunite & Fringing silicification \\
\hline Pyrophyllite & Quartz + pyrophyllite + pyrite \pm alunite & Vug-filling and fringing silicification \\
\hline Montmorillonite & $\begin{array}{l}\text { Montmorillonite/smectite }+ \text { pyrite } \pm \\
\text { chlorite } \pm \text { calcite }\end{array}$ & $\begin{array}{l}\text { Recessively weathering, argillic and } \\
\text { propylitic alteration }\end{array}$ \\
\hline Halloysite & Halloysite \pm pyrite & $\begin{array}{l}\text { Late fault zone; hydrothermal breccia } \\
\text { matrix }\end{array}$ \\
\hline $\begin{array}{l}\text { Montmorillonite } \pm \\
\text { dickite }\end{array}$ & $\begin{array}{l}\text { Montmorillonite/smectite } \pm \text { dickite }+ \\
\text { hematite }\end{array}$ & $\begin{array}{l}\text { Late Fe-rich clay-filled fracture and fault } \\
\text { zones cutting vuggy silica }\end{array}$ \\
\hline
\end{tabular}

${ }^{\mathrm{T}}$ Mineral assemblages defined on the basis of hand specimen identification, PIMA analyses, and limited petrographic study. Nearly all samples probably had pyrite, but pyrite is oxidized in most samples. 


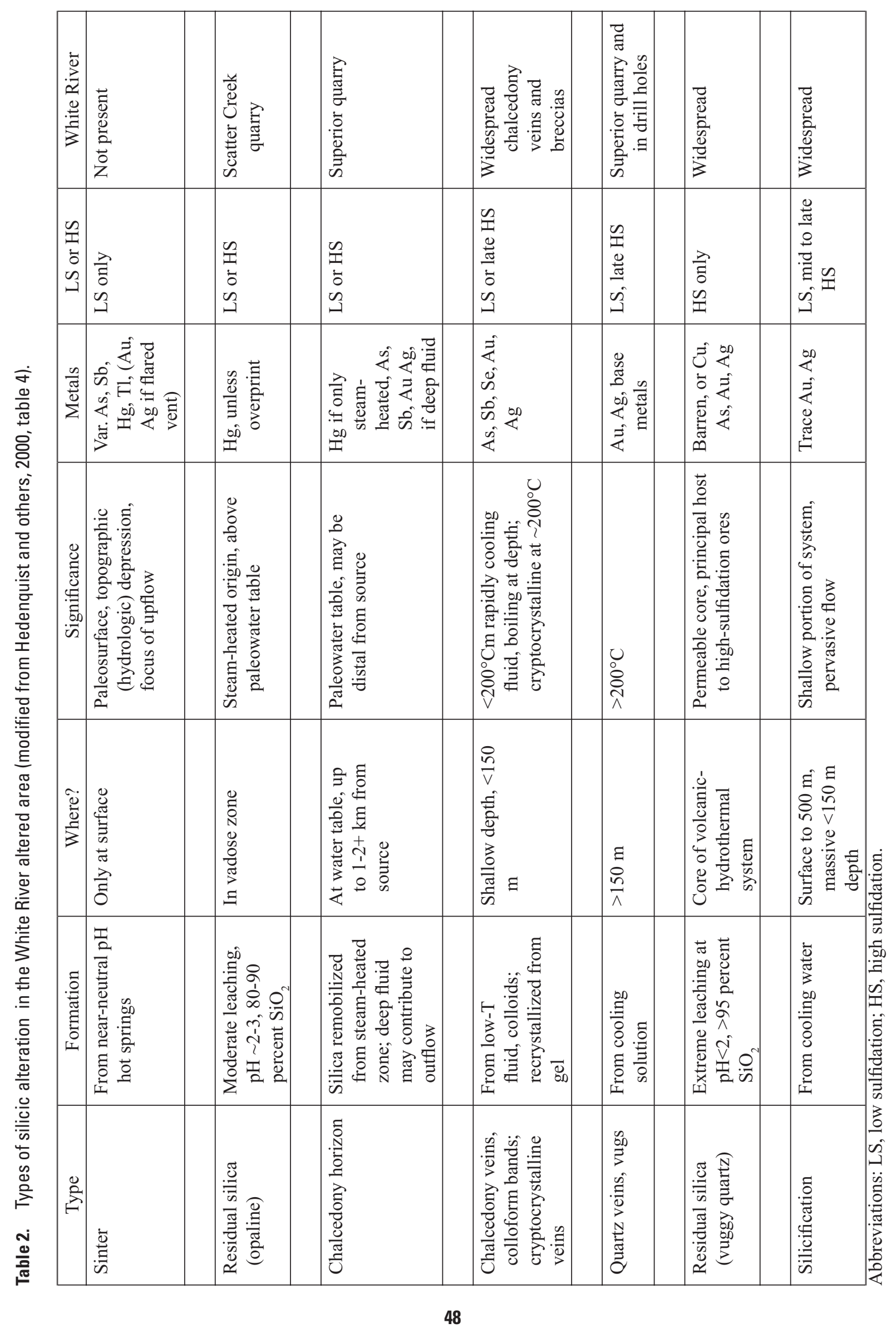


Field Guide to Hydrothermal Alteration in the White River Altered Area and in the Osceola Mudflow, Washington 
Field Guide to Hydrothermal Alteration in the White River Altered Area and in the Osceola Mudflow, Washington 
Field Guide to Hydrothermal Alteration in the White River Altered Area and in the Osceola Mudflow, Washington 
Field Guide to Hydrothermal Alteration in the White River Altered Area and in the Osceola Mudflow, Washington 